\title{
WATER USE ON THE SNAKE RIVER PLAIN, IDAHO AND EASTERN OREGON
}

\section{REGIONAL AQUIEER-SYSTEM ANALYSIS}

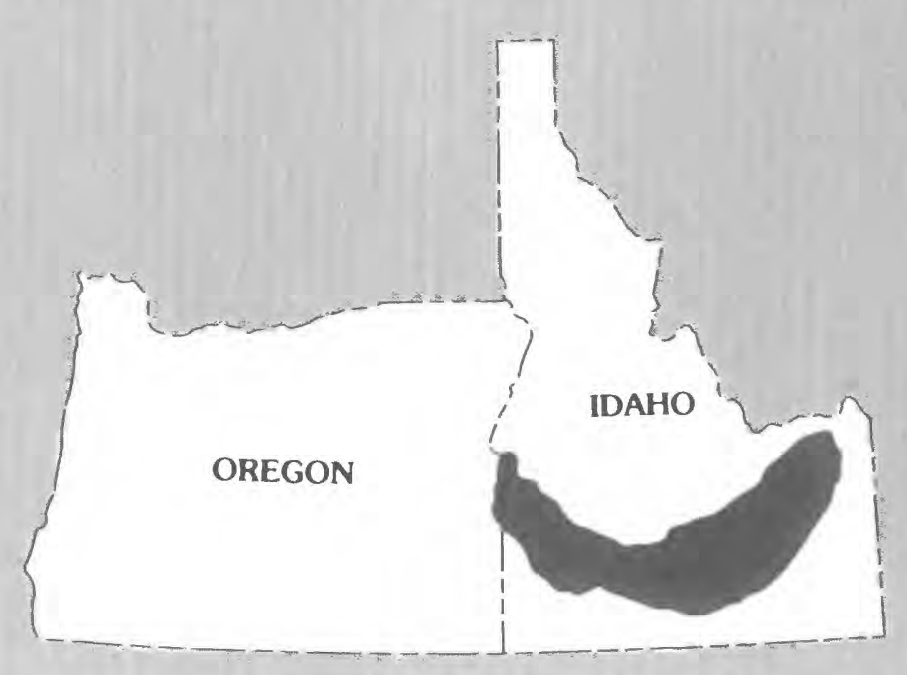


Instructions on ordering publications of the U.S. Geological Survey, along with prices of the last offerings, are given in the current-year issues of the monthly catalog "New Publications of the U.S. Geological Survey." Prices of available U.S. Geological Survey publications released prior to the current year are listed in the most recent annual "Price and Availability List." Publications that are listed in various U.S. Geological Survey catalogs (see back inside cover) but not listed in the most recent annual "Price and Availability List" are no longer available.

Prices of reports released to the open files are given in the listing "U.S. Geological Survey Open-File Reports," updated monthly, which is for sale in microfiche from the U.S. Geological Survey, Books and Open-File Reports Section, Federal Center, Box 25425, Denver, CO 80225. Reports released through the NTIS may be obtained by writing to the National Technical Information Service, U.S. Department of Commerce, Springfield, VA 22161; please include NTIS report number with inquiry.

Order U.S. Geological Survey publications by mail or over the counter from the offices given below.

\section{BY MAIL}

\section{Books}

Professional Papers, Bulletins, Water-Supply Papers, Techniques of Water-Resources Investigations, Circulars, publications of general interest (such as leaflets, pamphlets, booklets), single copies of Earthquakes \& Volcanoes, Preliminary Determination of Epicenters, and some miscellaneous reports, including some of the foregoing series that have gone out of print at the Superintendent of Documents, are obtainable by mail from

\section{U.S. Geological Survey, Books and Open-File Reports Federal Center, Box 25425 Denver, CO 80225}

Subscriptions to periodicals (Earthquakes \& Volcanoes and Preliminary Determination of Epicenters) can be obtained ONLY from the

\section{Superintendent of Documents Government Printing Orfice Washington, D.C. 20402} ments.)

(Check or money order must be payable to Superintendent of Docu-

\section{Maps}

For maps, address mail orders to

\section{U.S. Geological Survey, Map Distribution \\ Federal Center, Box 25286 \\ Denver, CO 80225}

Residents of Alaska may order maps from

\author{
Alaska Distribution Section, U.S. Geological Survey, \\ New Federal Building - Box 12 \\ 101 Twelfth Ave., Fairbanks, AK 99701
}

\section{OVER THE COUNTER}

Books

Books of the U.S. Geological Survey are available over the counter at the following Geological Survey Public Inquiries Offices, all of which are authorized agents of the Superintendent of Documents:

- WASHINGTON, D.C.--Main Interior Bldg., 2600 corridor, 18 th and C Sts., NW.

- DENVER, Colorado--Federal Bldg., Rm. 169, 1961 Stout St.

- LOS ANGELES, California--Federal BIdg., Rm. 7638, $300 \mathrm{~N}$. Los Angeles St.

- MENLO PARK, California--Bldg. 3 (Stop 533), Rm. 3128, 345 Middlefield Rd.

- RESTON, Virginia--503 National Center, Rm. 1C402, 12201 Sunrise Valley Dr.

- SALT LAKE CITY, Utah--Federal Bldg., Rm. 8105, 125 South State St.

- SAN FRANCISCO, California--Customhouse, Rm. 504, 555 Battery St.

- SPOKANE, Washington--U.S. Courthouse, Rm. 678, West 920 Riverside Ave..

- ANCHORAGE, Alaska--Rm. 101, 4230 University Dr.

- ANCHORAGE, Alaska--Federal Bldg, Rm. E-146, 701 C St.

\section{Maps}

Maps may be purchased over the counter at the U.S. Geological Survey offices where books are sold (all addresses in above list) and at the following Geological Survey offices:

- ROLLA, Missouri--1400 Independence Rd.

- DENVER, Colorado--Map Distribution, Bldg. 810, Federal Center

- FAIRBANKS, Alaska--New Federal Bldg., 101 Twelfth Ave. 


\title{
Water Use on the Snake River Plain, Idaho and Eastern Oregon
}

\author{
By S.A. GOODELL
}

$\begin{array}{lllllllllllllllllllllllllll}S & N & A & K & E & R & I & V & E & R & P & L & A & I & N & R & A & S & A & P & R & O & J & E & C & T\end{array}$

U.S. GEOLOGICAL SURVEY PROFESSIONAL PAPER 1408-E

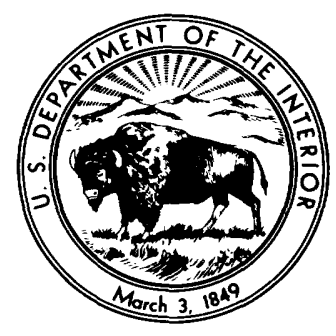

UNITED STATES GOVERNMENT PRINTING OFFICE, WASHINGTON : 1988 


\section{DEPARTMENT OF THE INTERIOR \\ DONALD PAUL HODEL, Secretary}

\section{U.S. GEOLOGICAL SURVEY}

Dallas L. Peck, Director

Library of Congress Cataloging-in-Publication Data

Goodell, S.A.

Water use on the Snake River Plain, Idaho and eastern Oregon.

(Regional aquifer-system analysis) (U.S. Geological Survey professional paper; 1408-E)

Bibliography: $p$.

Supt. of Docs. no.: I 19.16:1408-E

1. Water use-Snake River Plain (Idaho and Or.) I. Title. II. Series. III. Series: Geological Survey professional paper; 1408-E.

TD225.S47G66 1988

$333.91 ' 13^{\prime} 097961$

$86-600138$

For sale by the Books and Open-File Reports Section, U.S. Geological Survey, Federal Center, Box 25425, Denver, CO 80225 


\section{FOREWORD}

\section{THE REGIONAL AQUIFER-SYSTEM ANALYSIS PROGRAM}

The Regional Aquifer-System Analysis (RASA) Program was started in 1978 following a congressional mandate to develop quantitative appraisals of the major ground-water systems of the United States. The RASA Program represents a systematic effort to study a number of the Nation's most important aquifer systems, which in aggregate underlie much of the country and which represent an important component of the Nation's total water supply. In general, the boundaries of these studies are identified by the hydrologic extent of each system and accordingly transcend the political subdivisions to which investigations have often arbitrarily been limited in the past. The broad objective for each study is to assemble geologic, hydrologic, and geochemical information, to analyze and develop an understanding of the system, and to develop predictive capabilities that will contribute to the effective management of the system. The use of computer simulation is an important element of the RASA studies, both to develop an understanding of the natural, undisturbed hydrologic system and the changes brought about in it by human activities, and to provide a means of predicting the regional effects of future pumping or other stresses.

The final interpretive results of the RASA Program are presented in a series of U.S. Geological Survey Professional Papers that describe the geology, hydrology, and geochemistry of each regional aquifer system. Each study within the RASA Program is assigned a single Professional Paper number, and where the volume of interpretive material warrants, separate topical chapters that consider the principal elements of the investigation may be published. The series of RASA interpretive reports begins with Professional Paper 1400 and thereafter will continue in numerical sequence as the interpretive products of subsequent studies become available.

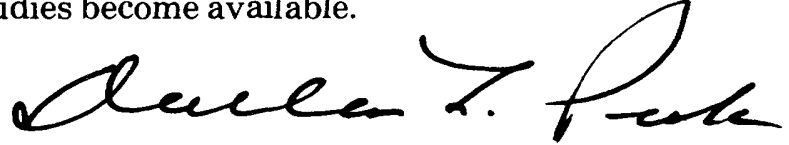

Dallas L. Peck Director 



\section{CONTENTS}

Foreword _. . . . . . . . . . . . .

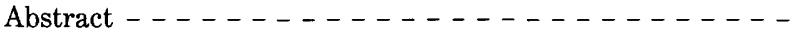

Well-numbering system $\ldots \ldots \ldots$

Introduction - . . . . . . . . . . . . .

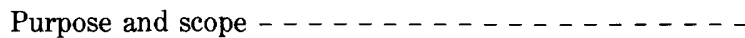

Previous investigations - - - - - - - - - -

Acknowledgments - . - . - . - . . . - -

Description of the study area

Physical setting - - - - - - $-\ldots-\ldots$

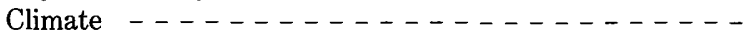

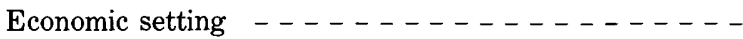

Irrigated agriculture - - - - - - - - - - - -

History of irrigation $-\ldots,-\ldots-\ldots$

Methods of estimating irrigation water use - - . - -

Pumped withdrawals of surface and ground water for irrigation - . . . . . . . . . . . . Pumpage calculations- - - - - - - - Accuracy of estimated pumpage - . . . . The constant $K \ldots \ldots$ Total head _.................

Gravity withdrawals of surface water for irrigation - . . . . . . . . . . .

\begin{tabular}{|c|c|c|}
\hline Page & & Pag \\
\hline III & Irrigated agriculture-Continued & \\
\hline E1 & Methods of estimating irrigation water use-Continued & \\
\hline 1 & Crop consumptive irrigation requirement $\ldots----$ & $\mathrm{E} 20$ \\
\hline 1 & Surface-water irrigation, $1980 \ldots-\cdots-\cdots$ & 2 \\
\hline 2 & Ground-water irrigation, $1980 \ldots \ldots \ldots$ & \\
\hline 2 & Hydrologic effects of irrigation $\ldots-\ldots-\ldots$ & \\
\hline 2 & Other offstream water uses $\ldots \ldots \ldots \ldots$ & \\
\hline 3 & Industrial $\ldots \ldots-\ldots$ & \\
\hline 3 & Aquaculture $-\ldots-\ldots-\cdots-\ldots-\ldots-\cdots--$ & \\
\hline 8 & Nonindustrial public supply $\ldots \ldots \ldots$ & \\
\hline 8 & Rural $\ldots-\ldots \ldots \ldots-\ldots-\ldots$ & \\
\hline 11 & Idaho National Engineering Laboratory - - - - - - - & \\
\hline 11 & Instream water uses $-\cdots \cdots-\cdots-\cdots$ & \\
\hline 16 & $\begin{array}{l}\text { Hydroelectric power generation }-\ldots-\ldots \\
\text { Minimum instream flows }-\ldots-\ldots\end{array}$ & \\
\hline 16 & Evapotranspiration from water bodies and undeveloped & \\
\hline 16 & lands $-\ldots, \ldots-\ldots-\ldots-\ldots-\ldots$ & \\
\hline 18 & Total water withdrawn and consumptive water use in & \\
\hline 19 & ------------------- & \\
\hline 19 & $\begin{array}{l}\text { Water-use trends, } 1945 \text { to } 1980 \ldots \ldots \\
\text { Summary }\end{array}$ & \\
\hline 20 & References cited $-----------------\cdots$ & \\
\hline
\end{tabular}

\section{ILLUSTRATIONS}

FIgURE 1. Diagram showing well-numbering system $\ldots \ldots \ldots \ldots \ldots \ldots \ldots$ 2-10. Maps showing:

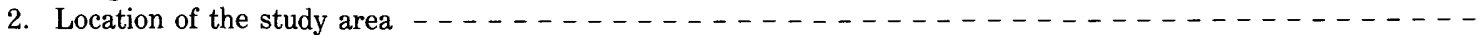

3. Gaging stations and geographic features $\ldots \ldots \ldots \ldots \ldots \ldots$

4. Irrigated acreage and other land uses, $1980 \ldots \ldots-\ldots, \ldots-\ldots, \ldots-\ldots$

5. Mean annual precipitation in the Snake River basin _ $\ldots \ldots \ldots$

6. Locations of weather stations $-\ldots \ldots \ldots \ldots$

7. Irrigated acreage, $1899 \ldots \ldots \ldots \ldots$

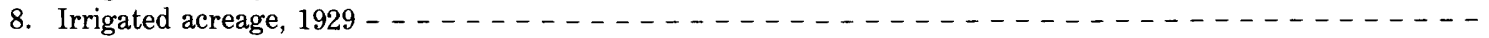

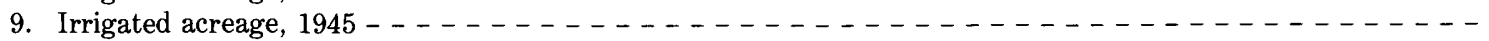

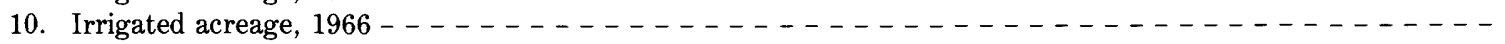

11-14. Graphs showing:

11. Relation between power consumed and volume of water pumped times total head _ _ _ _ . . . .

12. Estimated well drawdowns $\ldots \ldots \ldots \ldots \ldots \ldots$

13. Efficiencies of sample pumping stations _ $\ldots \ldots \ldots \ldots \ldots \ldots$

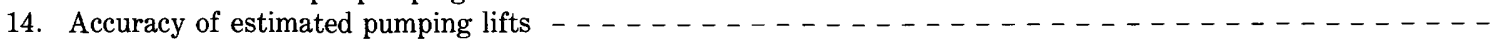

15. Map showing locations of major canals _ $\ldots \ldots \ldots \ldots$

16. Graph showing altitude of the Snake River and adjacent land surface

17. Map showing estimated ground-water pumpage, $1980 \ldots \ldots \ldots \ldots-\ldots, \ldots-\ldots, \ldots-\ldots-\ldots$

18. Graph showing well completion by rock type _ $\ldots \ldots \ldots \ldots$

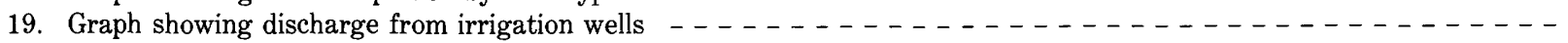

20-22. Maps showing:

20. Generalized depth to water $\ldots \ldots \ldots \ldots$

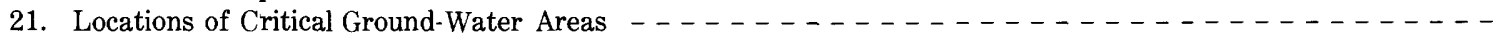

22. Estimated crop consumptive irrigation requirement for ground-water-irrigated areas $\ldots \ldots$ 
23-25. Graphs showing:

23. Water-level rises in three wells, 1900-1960 $\ldots \ldots \ldots \ldots$

24. Average annual ground-water discharge from the north side of the Snake River between Milner and

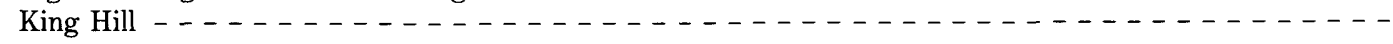

25. Declining water levels in well 8S-24E-31DAC1, in Minidoka County $\ldots \ldots \ldots$

26-29. Maps showing:

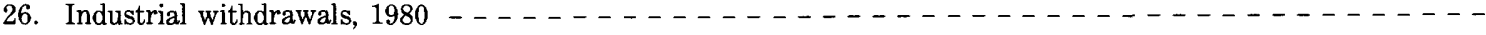

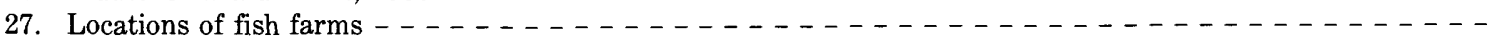

28. Public- and rural-supply withdrawals, $1980 \ldots-\ldots-\ldots-\ldots-\ldots$

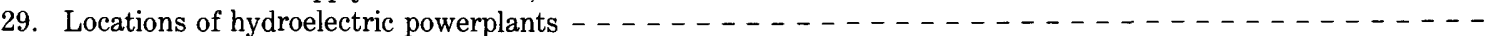

30. Graph showing trends in withdrawals for offstream uses, 1950-1980 $\ldots \ldots \ldots$

\section{TABLES}

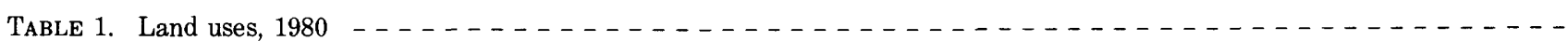

2. Mean monthly and annual precipitation and mean annual air temperature recorded at selected weather stations,

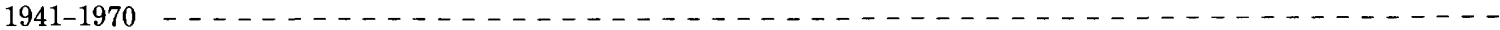

3. Acreage of major crops, $1980 \ldots \ldots \ldots$

4. Average rates of consumptive water use for crops recorded at selected weather stations _....................

5. Errors in pumpage estimates owing to errors in estimates of total head at two hypothetical wells - . . . . . - -

6. Average crop consumptive irrigation requirements recorded at selected weather stations _ $\ldots$

7. Irrigation diversions from the Snake River and major tributaries by gaged reach, $1980 \ldots \ldots$

8. Characteristics of irrigation wells $\ldots \ldots \ldots \ldots$

9. Upstream irrigated area and streamflow depletion for the Snake River at King Hill and Weiser, 1870-1940 - - - - - -

10. Industrial water use by county, $1980 \ldots \ldots \ldots \ldots \ldots$

11. Aquaculture water use by county, $1980 \ldots \ldots \ldots \ldots$

12. Nonindustrial public-supply water use and population served by county, $1980 \ldots \ldots$

13. Rural domestic and livestock water use by county, $1980 \ldots \ldots \ldots$

14. Water use for hydropower generation, $1980 \ldots \ldots \ldots \ldots \ldots$

15. Summary of offstream water withdrawals and consumptive use, $1980 \ldots$

16. Estimated water use in Idaho, 1945-1980 _ $\ldots \ldots \ldots \ldots$

\section{METRIC CONVERSION TABLE}

Inch-pound units in this report may be converted to International System of Units (SI) by using the following conversion factors:

\begin{tabular}{lcl}
\hline \multicolumn{1}{c}{ Multiply } & By & \multicolumn{1}{c}{ To obtain } \\
\hline acre & $4,046.9$ & square meter $\left(\mathrm{m}^{2}\right)$ \\
acre-foot (acre-ft) & $1,233.5$ & cubic meter $\left(\mathrm{m}^{3}\right)$ \\
cubic foot per second $\left(\mathrm{ft}^{3} / \mathrm{s}\right)$ & 0.02832 & cubic meter per second $\left(\mathrm{m}^{3} / \mathrm{s}\right)$ \\
foot (ft) & 0.3048 & meter $(\mathrm{m})$ \\
foot poundal (ft-pdl) & 0.04214 & joule $(\mathrm{J})$ \\
gallon (gal) & 0.003785 & cubic meter $\left(\mathrm{m}^{3}\right)$ \\
gallon per minute (gal $/ \mathrm{min})$ & 0.00006309 & cubic meter per second $\left(\mathrm{m}^{3} / \mathrm{s}\right)$ \\
horsepower (hp) & 746.043 & watt $(\mathrm{W})$ \\
inch (in.) & 25.40 & millimeter $(\mathrm{mm})$ \\
kilowatthour $(\mathrm{kWh})$ & $3,600,000$ & joule $(J)$ \\
megawatthour $(\mathrm{MWh})$ & $3,600,000,000$ & joule $(\mathrm{J})$ \\
mile (mi) & 1.609 & kilometer $(\mathrm{km})$ \\
pound, avoirdupois $(\mathrm{lb}$ avdp) & 453.6 & gram $(\mathrm{g})$ \\
pound per square inch $\left(\mathrm{lb} / \mathrm{in}^{2}\right)$ & 70.37 & gram per square centimeter $\left(\mathrm{g} / \mathrm{cm}^{2}\right)$ \\
square mile (mi $\left.{ }^{2}\right)$ & 2.590 & square kilometer $\left(\mathrm{km}^{2}\right)$
\end{tabular}

Temperature in degree Celsius $\left({ }^{\circ} \mathrm{C}\right)$ can be converted to degree Fahrenheit $\left({ }^{\circ} \mathrm{F}\right)$ as follows:

$$
{ }^{\circ} \mathrm{F}=(1.8)\left({ }^{\circ} \mathrm{C}\right)+32
$$




\title{
WATER USE ON THE SNAKE RIVER PLAIN, IDAHO AND EASTERN OREGON
}

\author{
By S.A. Goodell
}

\begin{abstract}
Amounts of water withdrawn and consumptively used for irrigation and other uses on the Snake River Plain were estimated to help determine hydrologic effects of ground- and surface-water use. Irrigation is the largest offstream use of water on the plain. Surface-water irrigation began in the 1840's and increased rapidly through the early 1900's. Use of ground water for irrigation accelerated after World War II. In 1980, about 3.1 million acres were irrigated: 1.0 million acres were irrigated with about 2.3 million acre-feet of ground water; 2.0 million acres were irrigated with about 12.7 million acre-feet of surface water; 0.1 million acres were irrigated with combined surface and ground water. Historical changes in aquifer storage and spring discharge are closely related to changes in irrigation practices.

Industries, including aquaculture, withdrew an estimated 1.97 million acre-feet of water. Withdrawals for other offstream uses, including public and rural supplies, totaled 132,000 acre-feet. Hydroelectric power generation is an economically important instream use of water. In 1980 , about 52 million acre-feet of surface water was used to generate 2.6 million megawatt-hours of electricity. Native vegetation evapotranspired an estimated 3.7 million acre-feet, and 900,000 acre-feet evaporated from bare ground and open water.
\end{abstract}

\section{WELL-NUMBERING SYSTEM}

The well-numbering system (fig. 1) used by the U.S. Geological Survey in Idaho indicates the location of wells within the official rectangular subdivision of the public lands, with reference to the Boise base line and meridian. The first two segments of the number designate the township and range. The third segment gives the section number; three letters, which indicate the $1 / 4$ section (160-acre tract), $1 / 4-1 / 4$ section ( 40 -acre tract), and $1 / 4-1 / 4-1 / 4$ section (10-acre tract); and the serial number of the well within the tract. Quarter sections are lettered A, B, C, and $\mathrm{D}$ in counterclockwise order from the northeast quarter of each section (fig. 1). Within quarter sections, 40-acre and 10-acre tracts are lettered in the same manner. For example, well 8S-24E-31DAC1 is in the $\mathrm{SW}^{1 / 4} \mathrm{NE}^{1 / 4} \mathrm{SE}^{1 / 4}$ sec. 31 , T. 8 S., R. 24 E., and is the first well inventoried in that tract.

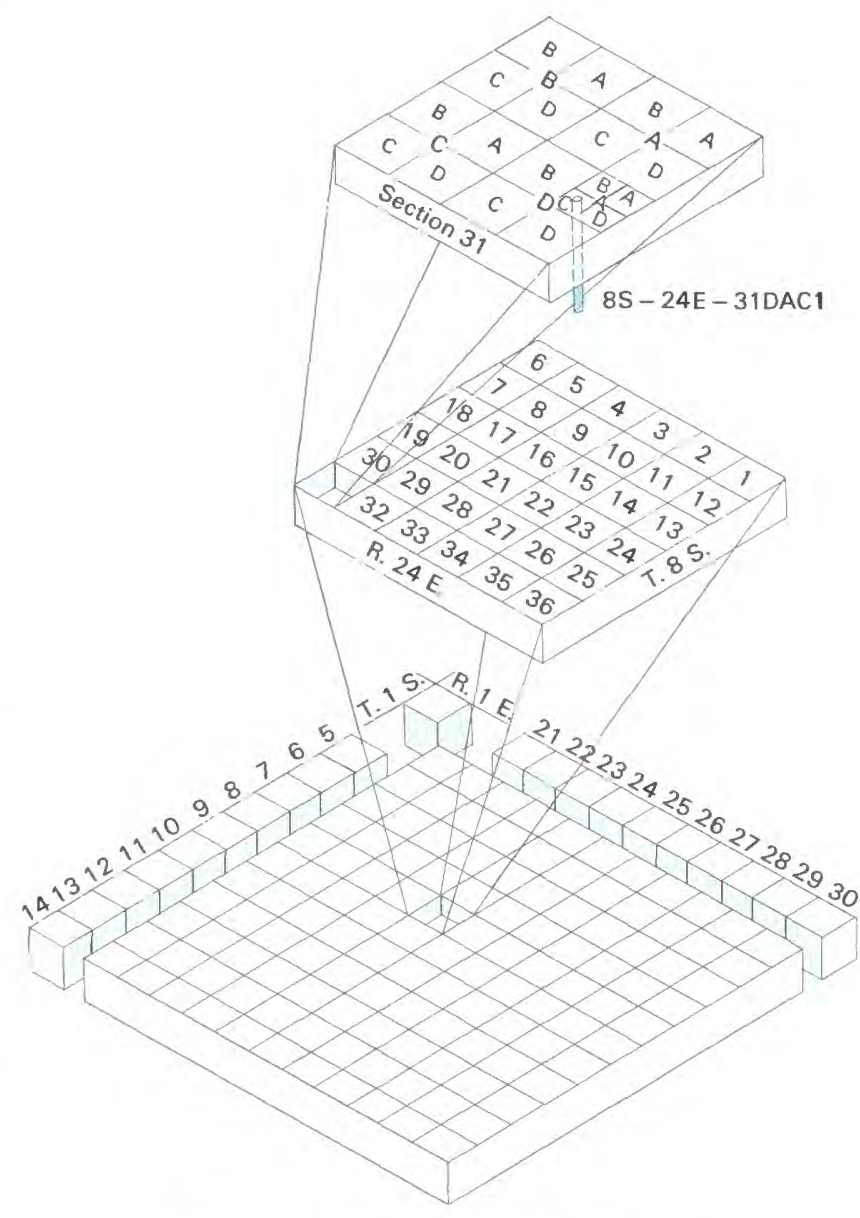

FIGURE 1.-Well-numbering system.

\section{INTRODUCTION}

This report is one in a series resulting from the U.S. Geological Survey's Snake River Plain RASA (Regional Aquifer-Systems Analysis) study that began in October 1979. 
Lindholm (1981) presented a plan of study for the Snake River Plain regional aquifer study. Preliminary interpretive reports generated by the RASA study to date (1986) include (1) a regional water-table map and description of the ground-water flow system (Lindholm and others, 1983 and 1985); (2) a description of the geohydrologic framework (Whitehead, 1984); (3) water budgets and flow in the Snake River (Kjelstrom, 1984); (4) water withdrawals for irrigation (Bigelow and others, 1984); (5) a map of land use showing irrigated acreage (Lindholm and Goodell, 1984); (6) a description of surface- and ground-water quality (Low, 1985); and (7) a ground-water flow model of the eastern Snake River Plain (Garabedian, 1984).

Final interpretive results of the Snake River Plain RASA study are presented in Professional Paper 1408, which consists of seven chapters as follows:

Chapter A is a summary of Professional Paper 1408.

Chapter B describes the geohydrologic framework, hydraulic properties of rocks composing the framework, and geologic controls on ground-water movement.

Chapter $\mathrm{C}$ describes ground-water/surface-water relations and ground-water budgets.

Chapter D describes solute geochemistry of the cold-water and geothermal systems.

Chapter E (this report) describes water use.

Chapter F describes results of ground-water flow modeling of the eastern Snake River Plain.

Chapter $\mathrm{G}$ describes results of ground-water flow modeling of the western Snake River Plain.

\section{PURPOSE AND SCOPE}

Historical hydrologic data indicate that human use of water, especially for irrigation, has significantly altered the natural water regimen of the Snake River Plain. However, the effects of water-use practices on the hydrologic system are poorly understood. To assess these effects and to insure continued availability of good quality water, managers need detailed regional water-use data. Water-use data also are needed as input to groundwater flow models.

Water use on the Snake River Plain is diverse and extensive, making direct measurement of even the most important uses impractical. Consequently, withdrawals for most water uses must be estimated. There is a particular need for estimates of ground- and surface-water withdrawals for irrigation, the largest water use.

The purposes of the present study were to (1) summarize the amounts and distribution of ground- and surface-water use on the Snake River Plain in 1980, (2) relate historical development of irrigation that led to present water-use patterns, and (3) describe the effects of water use on the hydrologic system.
The scope of this study included measurement of discharge and rate of power use at 79 irrigation pumping stations on the plain. Pump station data and annual power consumption data provided by utilities were used to estimate pumped withdrawals from 5,300 wells and 620 river pumping stations. Additional data from other studies, published reports, and files of the U.S. Geological Survey and State and Federal agencies were analyzed to supplement field data and to estimate the amount of water used for nonirrigation purposes.

\section{PREVIOUS INVESTIGATIONS}

The Snake River Plain was first surveyed for potentially irrigable lands in the late 1890's (Newell, 1903, p. 16, 162). Hoyt (1935) documented early surface-water developments for irrigation and power production in the Snake River Plain as of about 1932. Simons (1953) estimated annual increases in surface-water-irrigated acreage and resulting streamflow depletions from 1890 to 1946 for 17 subdivisions of the plain and adjacent areas. Irrigated acreage in 1945 was mapped by the U.S. Bureau of Reclamation (1946, p. 115, 151).

A study of ground water for irrigation on the Snake River Plain was conducted by Mundorff and others (1964). Since then, many studies have documented increases in irrigation-water use on the plain. Irrigated acreage in 1966 was mapped for the IWRB (Idaho Water Resource Board, 1970) and in 1975 for the IDWR (Idaho Department of Water Resources, 1978). The PNRBC (Pacific Northwest River Basins Commission, 1981) updated the 1975 irrigated acreage maps to reflect 1979 conditions. Ground-water pumpage for irrigation on the eastern part of the plain in 1966 was estimated by Norvitch and others $(1969$, p. 9) and in 1969 by Young and Harenberg (1971, p. 22).

Irrigated acreage in the Snake River Plain was defined as part of the Columbia-North Pacific Region Comprehensive Framework Study (PNRBC, 1970, 1971a). The Snake River Basin, Idaho and Wyoming Cooperative Study (U.S. Soil Conservation Service, 1976) comprehensively described irrigation practices and onfarm water use.

\section{ACKNOWLEDGMENTS}

Water-use studies involve analysis of numerous and diverse types of data collected by many State and Federal agencies and private companies. Estimates of 1980 pumpage depended on power consumption data provided by Fall River Rural Electric Cooperative, Inc.; Idaho Power Company; Lost River Electric Cooperative, Inc.; Raft River Electric Cooperative, Inc.; Rural Electric Company; Unity Light and Power Company; and Utah Power Company. Additional data and assistance were provided by 
Bonneville Power Administration, Idaho Department of Water Resources, and the U.S. Bureau of Reclamation. I thank the organizations and well owners who provided basic data for the study. Without the cooperation of many individuals and organizations, this study would not have been possible.

\section{DESCRIPTION OF THE STUDY AREA}

\section{PHYSICAL SETTING}

The Snake River Plain is an arcuate area of about $15,600 \mathrm{mi}^{2}$ in southern Idaho and eastern Oregon (fig. 2). The plain ranges in width from 30 to $75 \mathrm{mi}$ and in altitude from about $2,100 \mathrm{ft}$ above sea level in the west to about $6,000 \mathrm{ft}$ in the east. Most of the area is flat relative to surrounding mountains that range in altitude from 7,000 to $12,000 \mathrm{ft}$. The entire area is drained by the Snake River, whose course approximates the southern boundary of the plain.

The study area boundary is defined by geology and topography. Generally, contacts between Quaternary volcanic and sedimentary rocks and surrounding Tertiary and older rocks constitute the boundary. Where major rock types extend beyond the plain, the boundary is defined by topography.

For purposes of the study, the plain was divided in the vicinity of King Hill into eastern and western parts (fig. 2), which have significantly different geologic and hydrologic characteristics. A detailed description of the geohydrologic framework of the Snake River Plain was presented by Whitehead (1984).

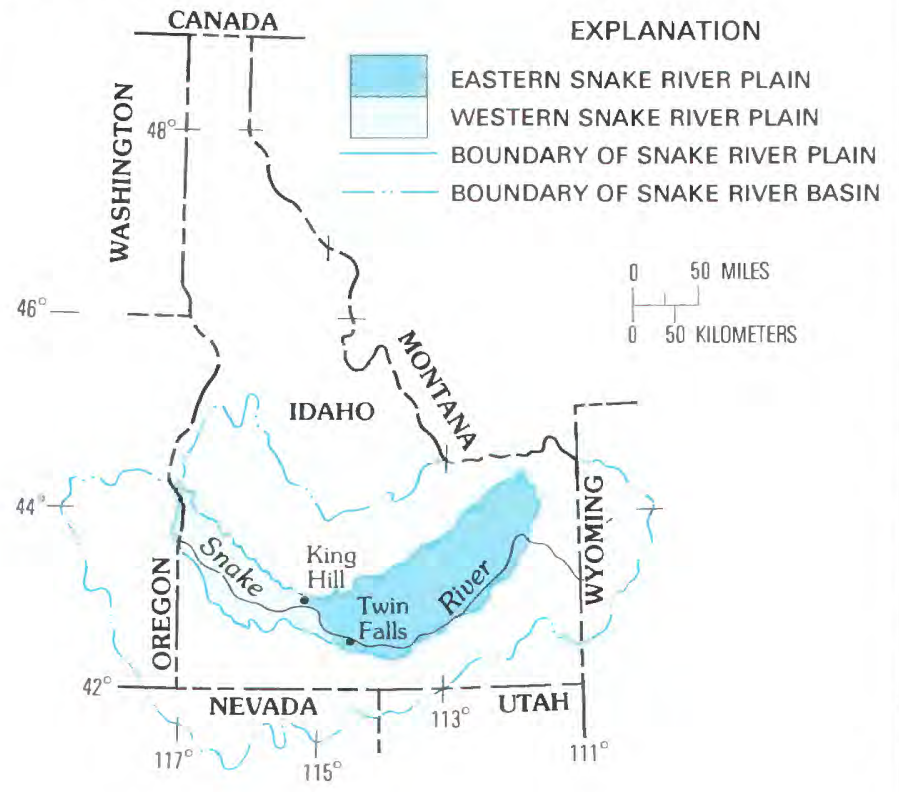

The eastern plain is a structural downwarp filled primarily with Quaternary basaltic lava flows and interbedded sedimentary rocks along the margins. With local exceptions, the basalt aquifer yields large volumes of good quality water and is the main source of ground-water supply on the eastern plain.

The western plain is a graben filled with a sequence of Tertiary and Quaternary sedimentary and igneous rocks, primarily volcanic. Rocks in the western plain have more variable water-yielding characteristics than rocks in the eastern plain. Generally, sand and gravel zones and basalt are the most productive aquifers.

Ground-water systems underlying both the eastern and western plain are recharged by deep percolation of excess irrigation water, leakage from canals, seepage from streams flowing onto and over the plain, underflow from tributary basins and highlands bordering the plain, and direct precipitation over the plain. Major components of ground-water discharge are spring flow to the Snake River, seepage to rivers, underflow, ground-water pumpage, and evapotranspiration. Springs discharging to the Snake River between Twin Falls and King Hill account for about half of the 8 million acre-ft of annual ground-water discharge in the eastern plain. Annual discharge in the western plain is about 2 million acre-ft. Detailed groundwater and basin budgets for the Snake River Plain were presented by Kjelstrom (1984).

Both the eastern and western plain are drained by the Snake River and its tributaries. The Snake River originates in western Wyoming, enters the plain about $18 \mathrm{mi}$ northeast of Idaho Falls (fig. 3), and flows generally westward to Milner in a shallow but well-defined channel. Included in that reach is American Falls Reservoir, the largest instream storage in Idaho. For more than $200 \mathrm{mi}$ downstream from Milner, the river is entrenched as much as $700 \mathrm{ft}$ below the general altitude of the plain in alternating canyons and broad valleys. On the far western plain, the altitude of the plain approaches that of the river channel until the river is only slightly entrenched near Payette. North of Weiser, the Snake River leaves the plain and enters a steep canyon several hundred feet deep.

Major Snake River tributaries are shown in figure 3. Except for Big and Little Wood Rivers, nearly all discharge from tributary streams north of the eastern plain seeps into the aquifer system.

Irrigated agriculture and other land uses on the Snake River Plain in 1980 were mapped from digital Landsat data (Lindholm and Goodell, 1984). Figure 4 is the resulting land-use map and table 1 describes the land-use classes. Of the 9.8 million acres on the plain, about 5.2 million acres, or 53 percent, are rangeland, and 3.1 million acres are irrigated agriculture. Another 1.0 million acres are barren. Most of the barren area is exposed lava flows with little or no soil development. 


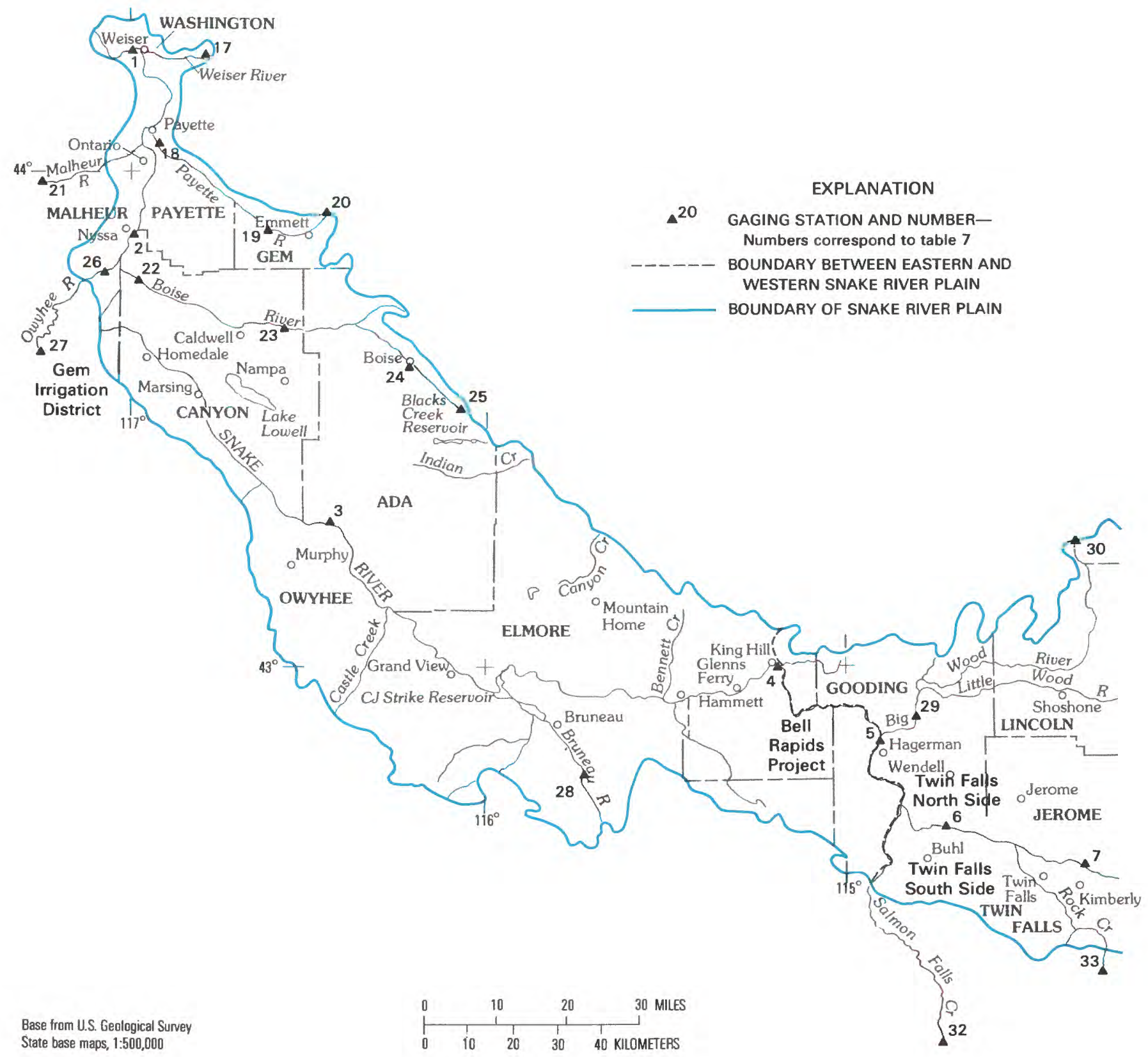

FIGURE 3.-Gaging stations and geographic features. 


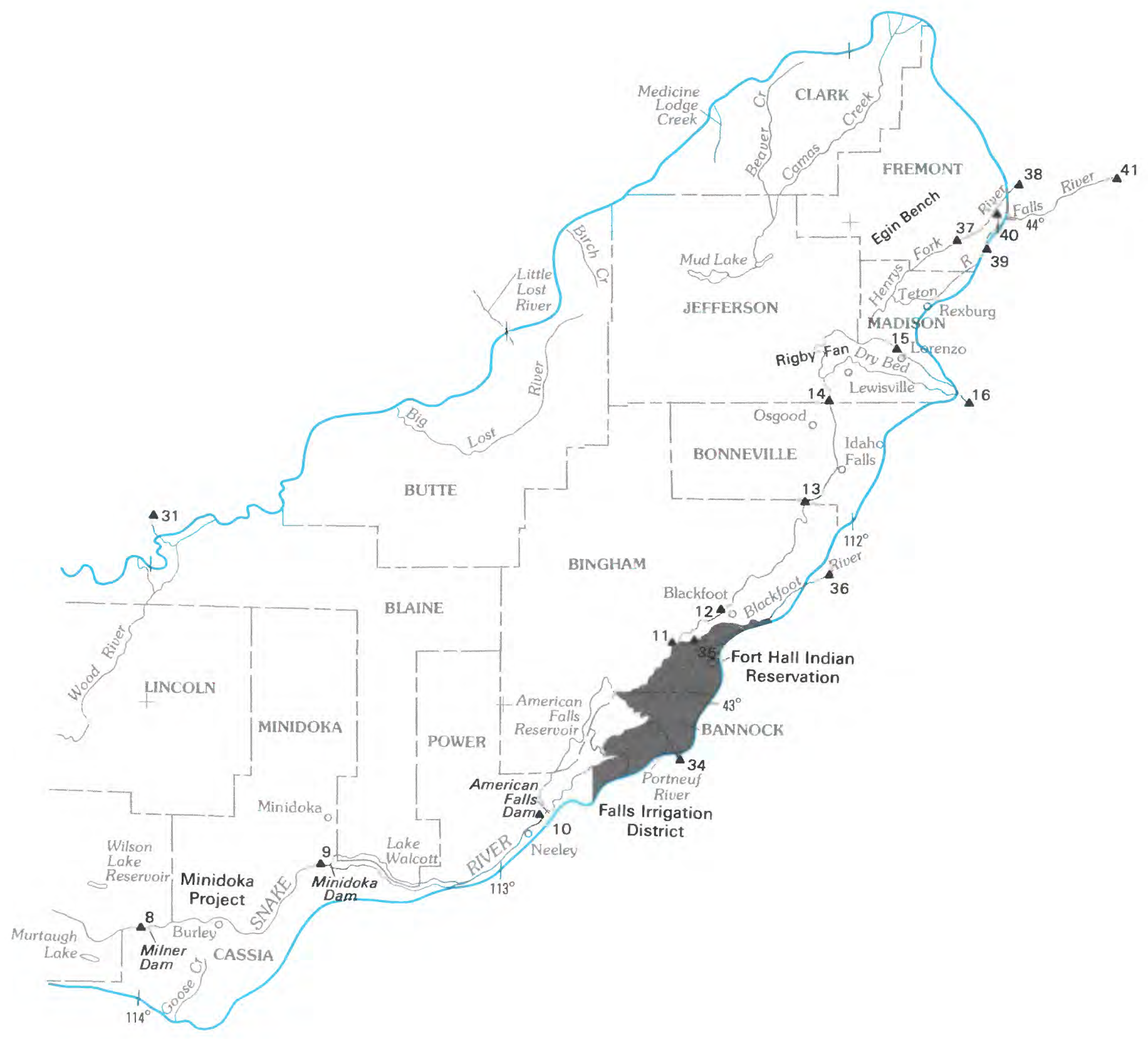

Figure 3.-Continued. 


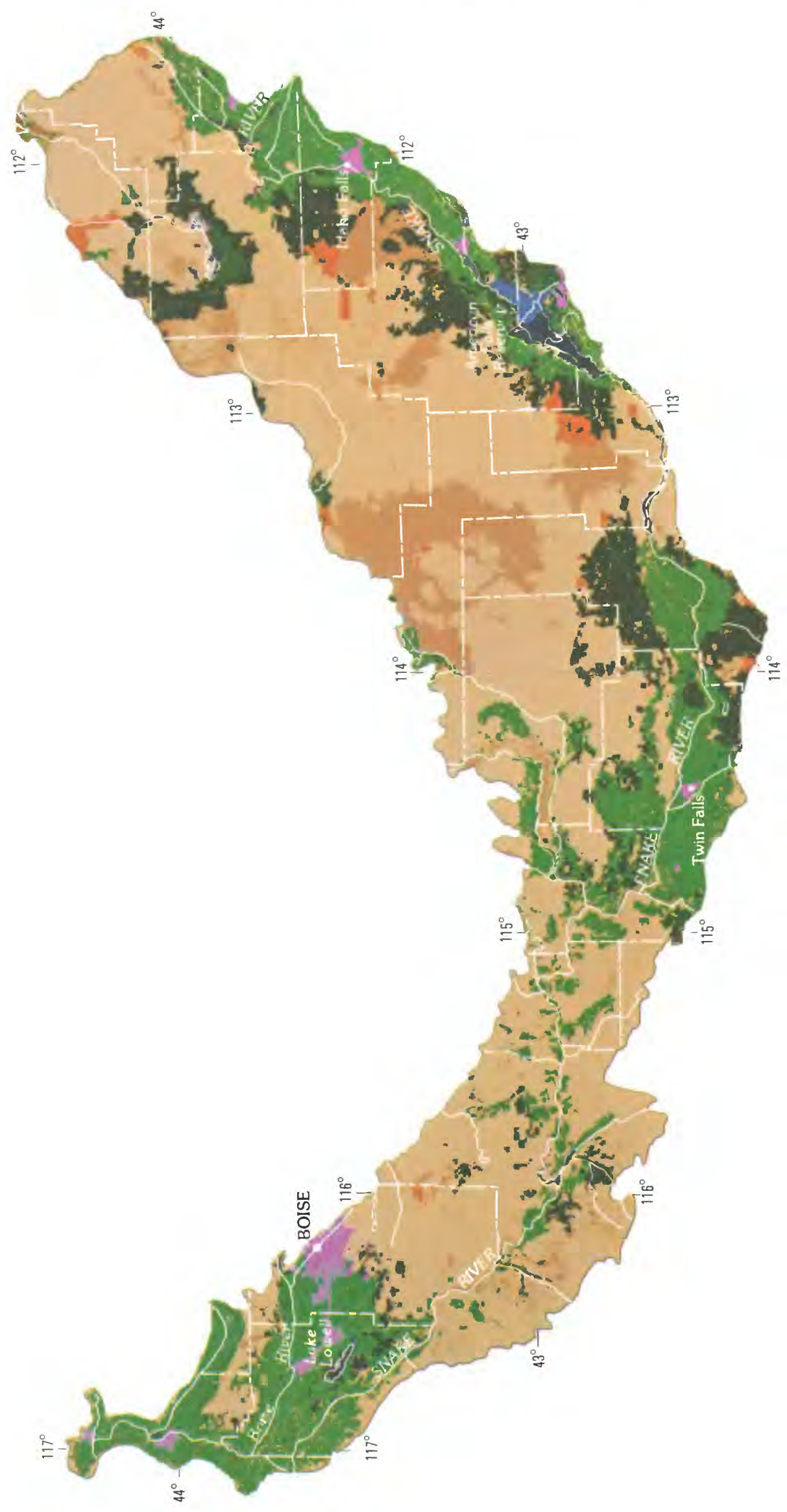




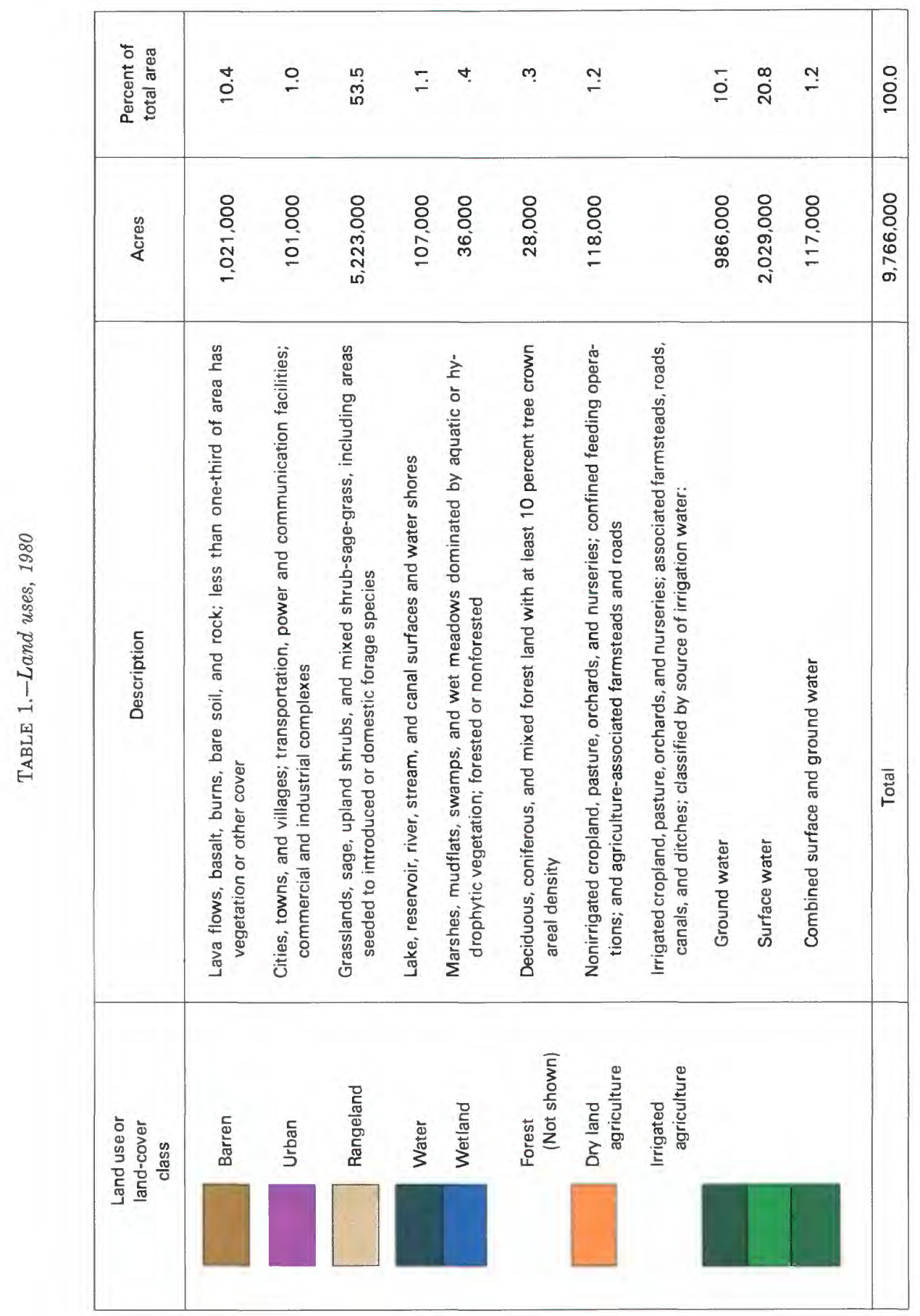




\section{CLIMATE}

The climate of the Snake River Plain is semiarid. Precipitation is sparse; winters are cold and summers are hot. Only a few places receive sufficient precipitation for nonirrigated farming. Precipitation is least in July and August and fairly evenly distributed throughout the rest of the year (table 2). However, annual precipitation varies greatly from year to year. Mean annual precipitation recorded at most weather stations on the plain ranges from 6 to $12 \mathrm{in.}$ On the edges and in the northeastern part, higher altitudes and orographic effects result in as much as 20 in. of precipitation (fig. 5). Annual precipitation amounts to about 8.2 million acre-ft; 5.8 million acre-ft on the eastern part and 2.4 million acre-ft on the western part (Kjelstrom, 1984). Most surface-water inflow and ground-water recharge from tributary basins originate as precipitation on the surrounding mountains, which receive as much as 60 in. annually.

Mean annual air temperatures recorded at weather stations in or near the study area (fig. 6) range from $41.0^{\circ} \mathrm{F}\left(5.0^{\circ} \mathrm{C}\right)$ at Ashton $1 \mathrm{~S}$ (about 50 mi northeast of Idaho Falls) to $52.3^{\circ} \mathrm{F}\left(11.3{ }^{\circ} \mathrm{C}\right)$ at Grand View $2 \mathrm{~W}$ (table 2). January is usually the coldest month and July the warmest. Average number of frost-free days ranges from 95 in the Henrys Fork area to 160 near Boise.

Potential evapotranspiration on the plain ranges from about 19 to $30 \mathrm{in} . / \mathrm{yr}$. Actual evapotranspiration on nonirrigated land is limited by the amount of precipitation.

In a study of arid rangelands in Arizona, evapotranspiration equaled 100 percent of summer precipitation and 80 to 90 percent of winter precipitation (Rich, 1952, p. 983,984$)$. Evapotranspiration accounts for 89 percent of annual precipitation in the Raft River valley, south of the Snake River Plain (Walker and others, 1970, p. 91). These estimates correspond with estimates of 0.5 to $2.0 \mathrm{in} . / \mathrm{yr}$ of runoff from the plain (PNRBC, 1970, p. 364, 429). Most runoff from rangelands originates as winter precipitation stored as snow. Some runoff also occurs during spring, summer, and fall rainstorms of high intensity or long duration. Only a small percentage of precipitation infiltrates to the aquifer system.

\section{ECONOMIC SETTING}

Irrigated agriculture, livestock production, and foodprocessing industries dominate the economy of the Snake River Plain. Agriculture is Idaho's largest industry; total 1980 cash receipts from farm marketing exceeded $\$ 2.0$ billion (Idaho Crop and Livestock Reporting Service, 1982 , p. 14). About 50 percent of agricultural land in Idaho, 85 percent of the irrigated acreage, and 25 percent of the rangeland are on the Snake River Plain.

About 5.2 million acres (53 percent of the plain area) are rangeland (fig. 4). Sheep and cattle grazed on public

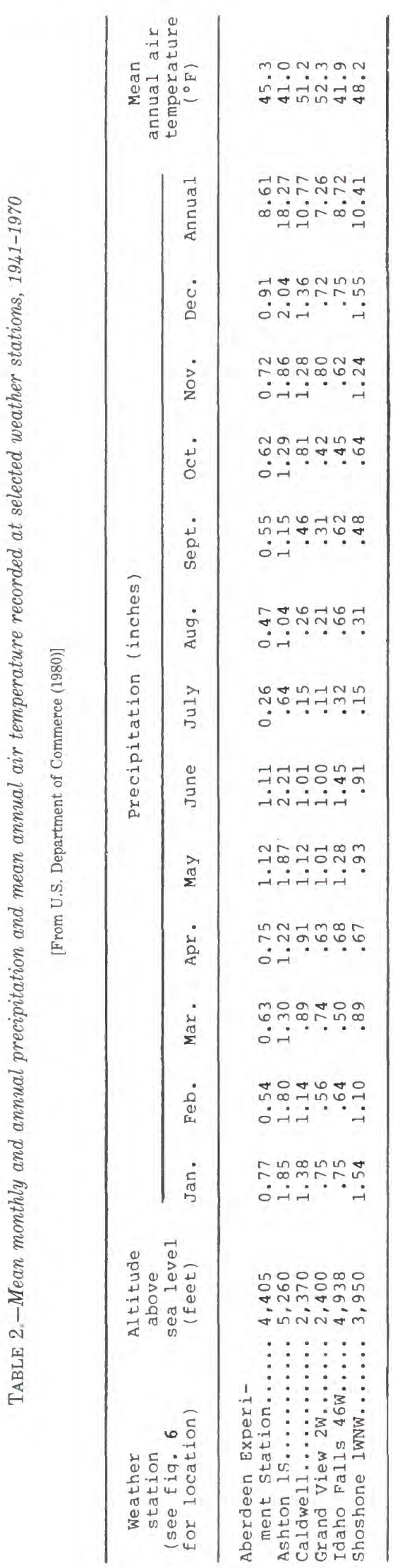




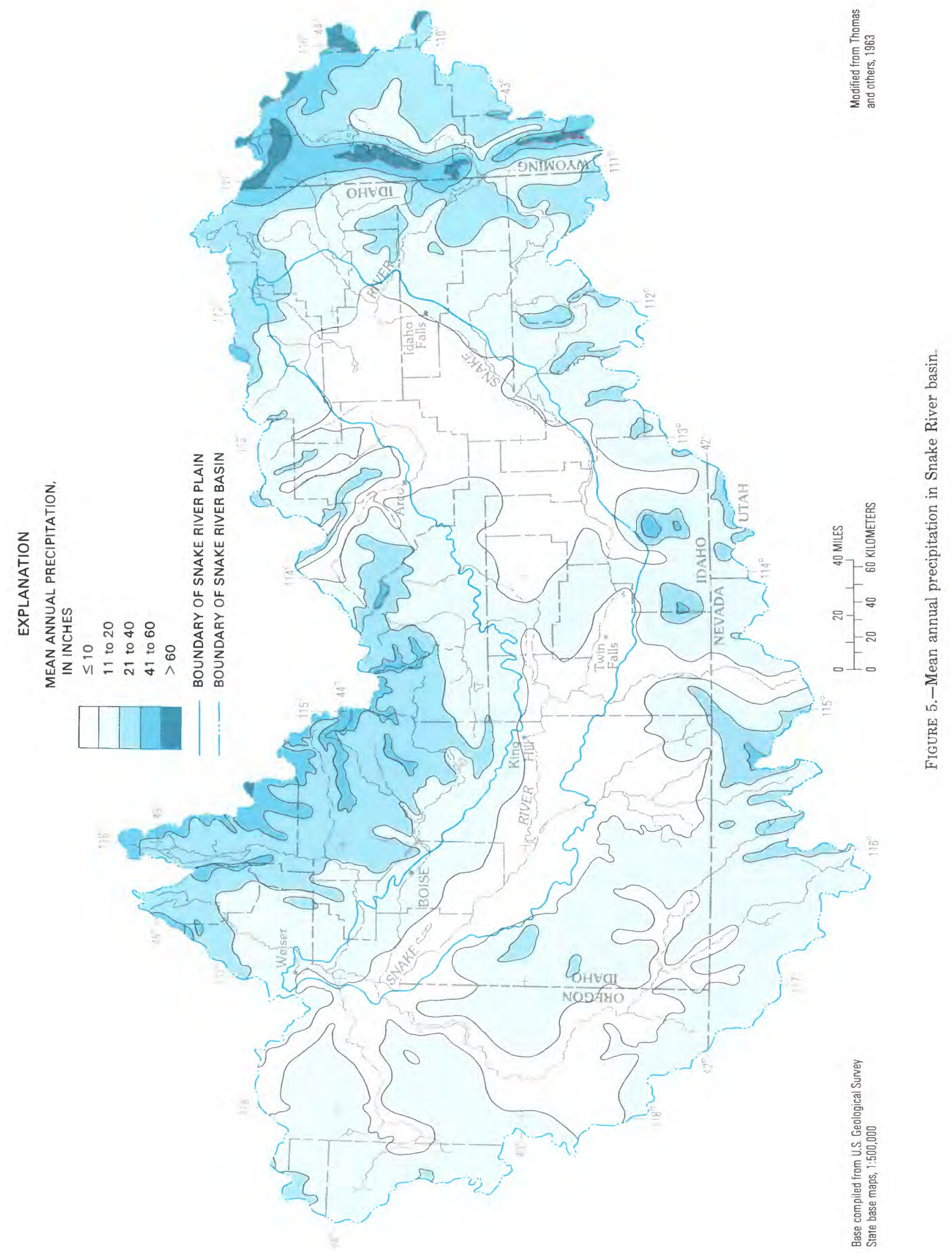




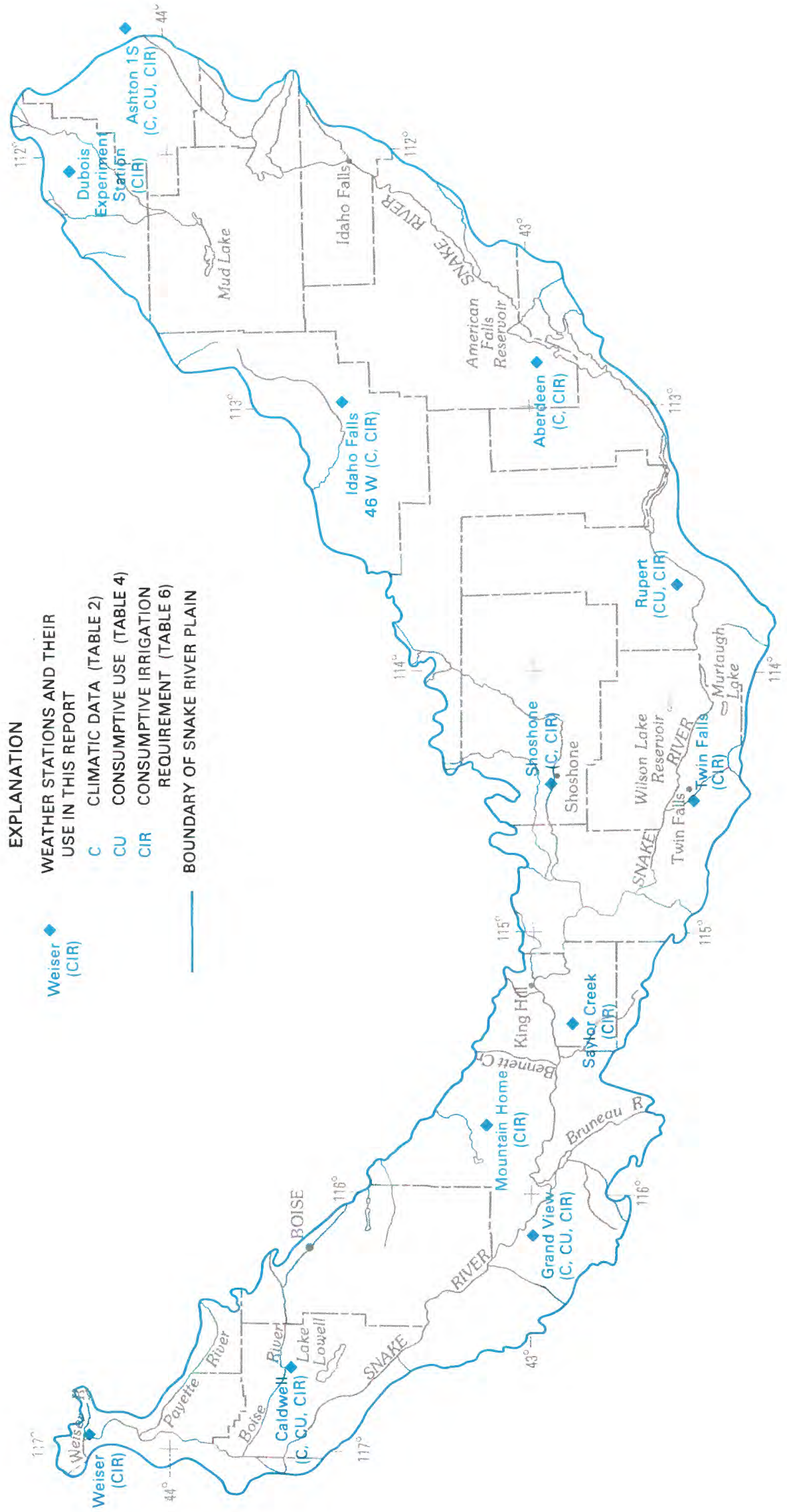

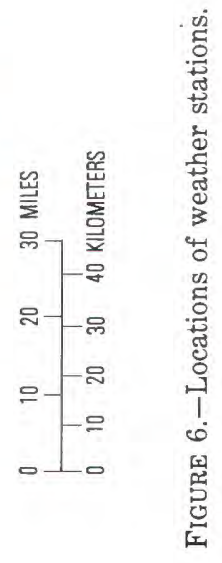


and private lands account for about 30 percent of Idaho's total cash receipts from farm marketing (Idaho Division of Economic and Community Affairs, 1983).

About 3.1 million acres (32 percent) of the Snake River Plain are irrigated. Principal irrigated crops include potatoes, small grains, sugar beets, and hay.

Commercial fish farming is another industry on the Snake River Plain that depends on the availability of good quality water. Springs discharging from the north canyon wall of the Snake River between Twin Falls and Hagerman are uniquely suited to trout farming. Seventy percent of the Nation's commercially produced trout are grown in Idaho (Klontz and King, 1975, p. 53).

\section{IRRIGATED AGRICULTURE}

Irrigated agriculture is by far the largest use of water in Idaho, and most of Idaho's irrigated acreage is concentrated on the Snake River Plain. Statewide, irrigation accounts for about 90 percent of withdrawals for offstream uses and more than 95 percent of consumptive water use (Solley and others, 1983, p. 36, 38). About 85 percent of the State's irrigated acreage is on the Snake River Plain.

In 1980 , an estimated 3.1 million acres of the plain were irrigated with 15 million acre-ft of water. About 2.0 million acres were irrigated with 12.7 million acre-ft of surface water pumped or diverted by gravity from rivers and streams on or near the plain. Another 1.0 million acres were irrigated with 2.3 million acre-ft of ground water pumped from about 5,300 wells. The remaining 0.1 million acres were irrigated with combined surface and ground water.

Estimated 1980 acreage of major crops on the plain is shown in table 3 . In general, most potatoes and sugar beets are grown on the eastern plain and smaller acreages of specialty crops such as mint, onions, hops, seed crops, and orchard fruits are grown on the western plain. Grains, hay, pasture, and some row crops are grown on both the eastern and western plain.

TABLE 3.-Acreage of major crops, 1980

\begin{tabular}{|c|c|}
\hline Crop & Acres \\
\hline Small grains....... & $1,208,000$ \\
\hline нау............ & 749,000 \\
\hline Pasture........... & 320,000 \\
\hline Potatoes......... & 185,000 \\
\hline Sugar beets...... & 110,000 \\
\hline Other............ & 560,000 \\
\hline Total..... & $3,132,000$ \\
\hline
\end{tabular}

Crop consumptive use of water varies with crop type and location on the Snake River Plain. Selected seasonal consumptive-use rates from Sutter and Corey (1970) are shown in table 4 . Generally, alfalfa, potatoes, and sugar beets have the highest consumptive-use rates at all locations. Row crops such as corn, small vegetables, and beans use less water. The highest consumptive-use rates for all crops are in the hot, dry central and western parts of the plain. At Grand View, alfalfa uses an average of 34 in. of water annually. The northeastern edge of the plain is generally cooler and more moist, and evapotranspiration rates are lower. Near Ashton, alfalfa uses an average of only $18 \mathrm{in}$. of water annually.

Crop-irrigation requirements (seasonal evapotranspiration less precipitation available to plants) also depend on crop type and location on the plain. Irrigation requirements vary from year to year, depending on temperatures and amount and seasonal distribution of precipitation. Winter, spring, and fall precipitation will reduce irrigation-water withdrawals if adequate soil moisture delays the start of irrigation in the spring or hastens its end in the fall. Scant precipitation during summer months has less effect on irrigation-water withdrawals.

The amount of water applied to crops generally exceeds irrigation-water requirements because of onfarm losses. Water evaporates from exposed water surfaces in gravitydistribution systems. Runoff and seepage occur when more water is applied than can be evapotranspired or absorbed and retained by the soil. Water also seeps from unlined ditches. The U.S. Soil Conservation Service (1977, p. 25) estimated that about 40 percent of water diverted for irrigation in the Snake River basin is lost to evaporation, runoff, and seepage.

Gravity distribution is the most common irrigation method on the plain. The U.S. Soil Conservation Service (1977, p. 66-67) estimated about 65 percent of irrigated area is served by gravity systems and 35 percent by sprinkler systems. Since the 1960's, total area irrigated with sprinklers has increased, particularly in groundwater-irrigated areas. This is due, in part, to development of lands unsuitable for gravity irrigation. Also, increasing energy costs associated with pumping water have made efficient water-distribution systems more economical.

\section{HISTORY OF IRRIGATION}

Irrigation has been practiced on the Snake River Plain for about 140 years. The first reported irrigation was in 1843 on lands adjacent to the Boise River (Caldwell and Wells, 1974, p. 31). By 1864, most easily irrigable lands on the Boise River flood plain were in production. Local interest in expanding irrigation beyond the flood plain was stimulated by a rapidly increasing population. Several private companies constructed small canal systems that 
TABLE 4.-Average rates of consumptive water use for crops recorded at selected weather stations

[Modified from Sutter and Corey (1970); Consumptive-use rates in inches; -, no data available]

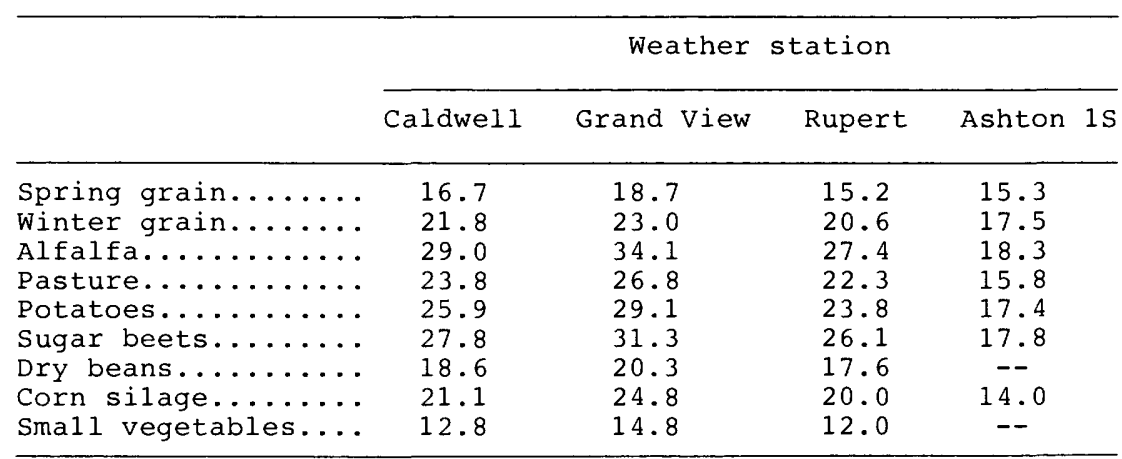

brought water to higher grounds. Development of remaining irrigable lands required major engineering projectsprojects too expensive for small, local enterprises.

Irrigation on the eastern plain began in about 1880 and followed the same development sequence as in the Boise River valley. Irrigation along the Snake River above Blackfoot (mainly on the Rigby Fan) and along the Henrys Fork and Teton Rivers was concentrated initially on lands adjacent to the rivers or within reach of short canals.

In the 1880's, favorable legislation by Congress encouraged reclamation of desert lands throughout the arid Western States. Resulting development brought irrigated acreage on the Snake River Plain to about 550,000 acres by 1899 (fig. 7), an increase of more than 100 percent over the preceding 10 years (Newell, 1903, p. 161).

With effective use of provisions of the Carey Act of 1894 and the Reclamation Act of 1902, irrigated acreage expanded rapidly in the early 1900 's. Federal legislation facilitated the transfer of public lands to individuals for private reclamation and provided financing for large-scale reclamation projects. The new Federal involvement provided coordination and funding for construction of dams, reservoirs, and canals, which, in turn, stimulated expansion of irrigated acreage.

The Twin Falls Project in the south-central part of the plain was one of the largest projects developed under the Carey Act. Beginning in 1905, Snake River water was diverted at Milner Dam and conveyed about $40 \mathrm{mi}$ to irrigate lands north and south of the river. Within 10 years, more than 300,000 acres were irrigated in the Twin Falls Project.

The Boise and Minidoka Projects were developed under the Reclamation Act. The Boise Project was approved in 1906, after which storage facilities were added, canals completed, and the first water delivered in 1907. Irrigated acreage increased steadily and, with the completion of Arrowrock Reservoir (about 15 mi east of Boise) in 1915, expanded beyond the Boise River valley. The Minidoka Project was authorized in 1904 and, starting in 1907, delivered irrigation water to about 120,000 acres on the north and south sides of the Snake River.

Water rights for most unregulated flow in the Snake River were decreed by 1908 and, in low water years, supplies were inadequate. Supply was augmented by federally financed construction of additional dams and reservoirs, both on and off the plain. A summary history of reservoir development and changes in storage capacity was presented by Kjelstrom (1984).

By 1929, the land boom had passed its peak and irrigated acreage on the Snake River Plain temporarily stabilized at about 2.2 million acres (fig. 8). Around 1920, average per-acre value of crops began falling and reached an extreme low in 1932 (Caldwell and Wells, 1974, p. 63). Low crop values and loss of markets owing to the nationwide depression precluded large increases in irrigated agriculture. During the Depression and World War II, Federal reclamation projects were small in scale. Federal aids to irrigation in the 1930 's, such as Milner-Gooding Canal and Owyhee Reservoir (about 52 mi west of Boise, off the map), resulted primarily in greater reservoir storage capacity, a more stable water supply, and local increases in irrigated acreage.

Between 1929 and 1945, irrigated area increased to about 2.5 million acres. Most of this area was irrigated with surface water (fig. 9). In earlier years, a few irrigation wells had been drilled, but ground water did not become an important source of irrigation water until the late 1940 's. By that time, surface-water rights to unregulated flows had long been appropriated, the best reservoir sites were developed, lands adjacent to rivers were already irrigated, and irrigation-pump technology had improved enough to make ground-water pumping economically feasible. When demand for irrigation water increased after World War II, ground water was the logical source of supply.

The Mud Lake area was one of the first areas of extensive ground-water development. As early as the 1920's, some irrigators withdrew water from shallow wells 

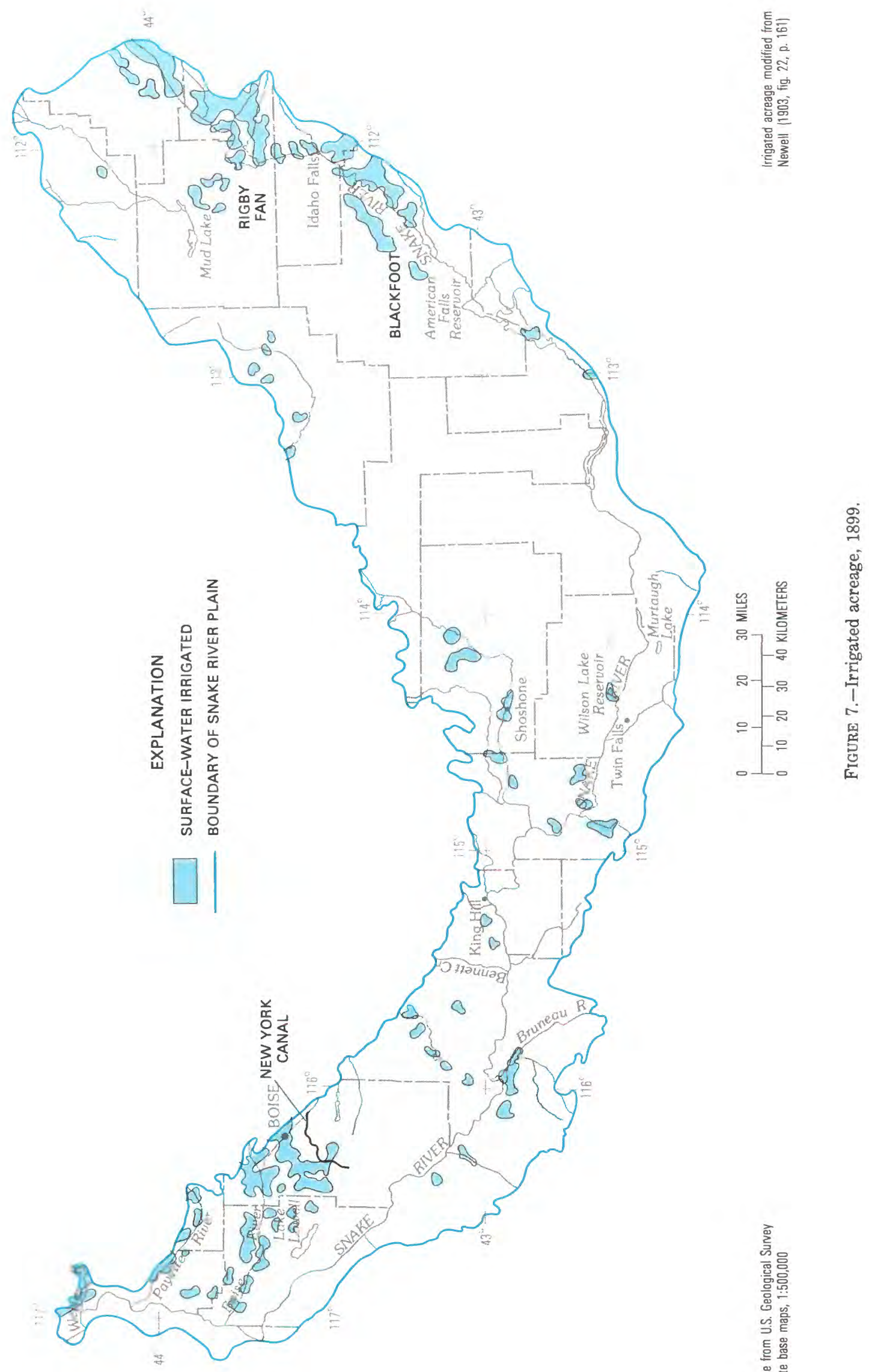


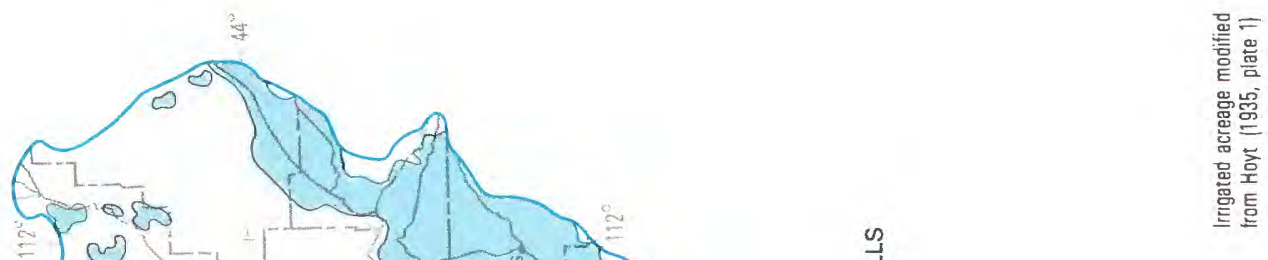

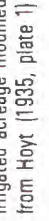
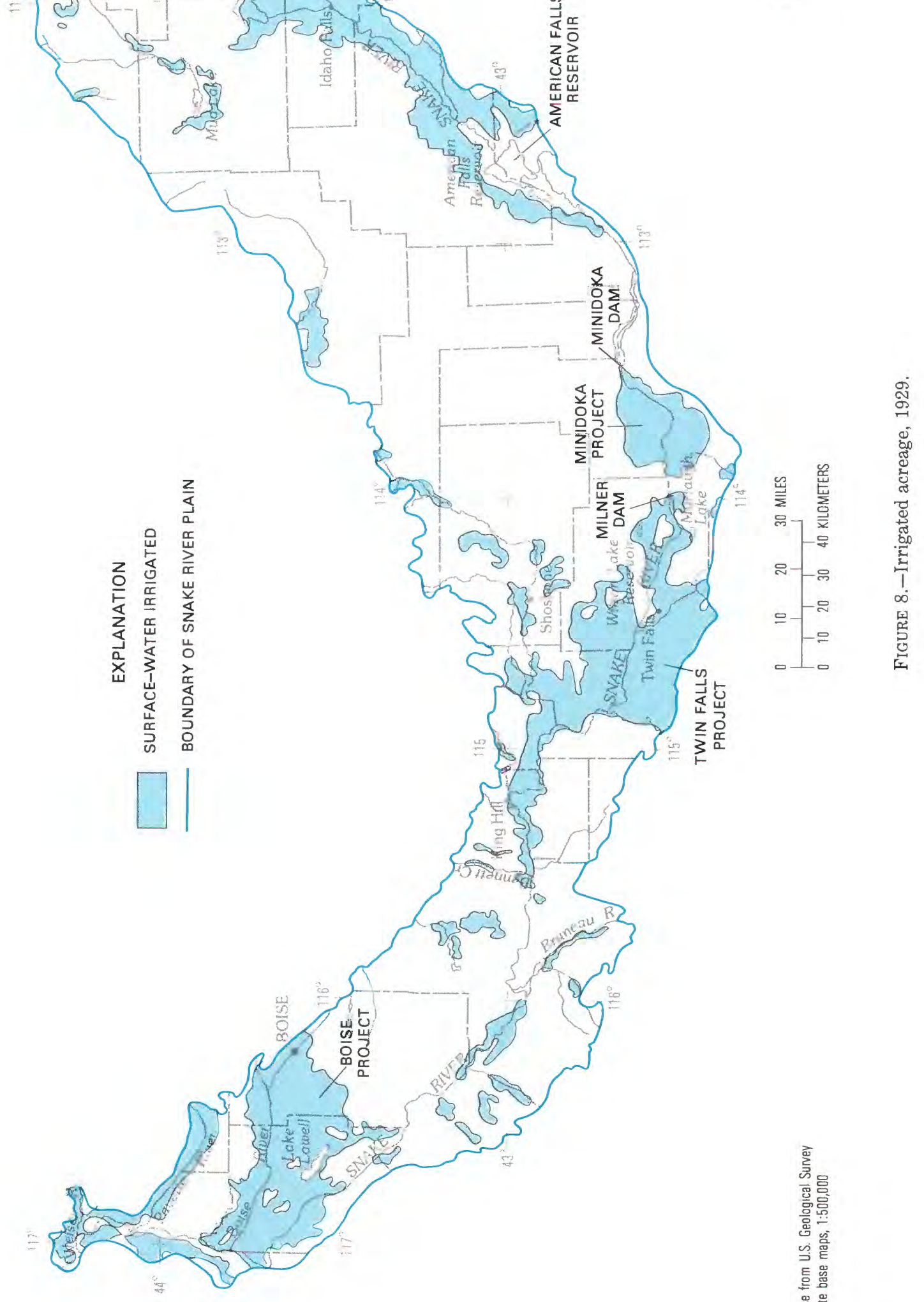

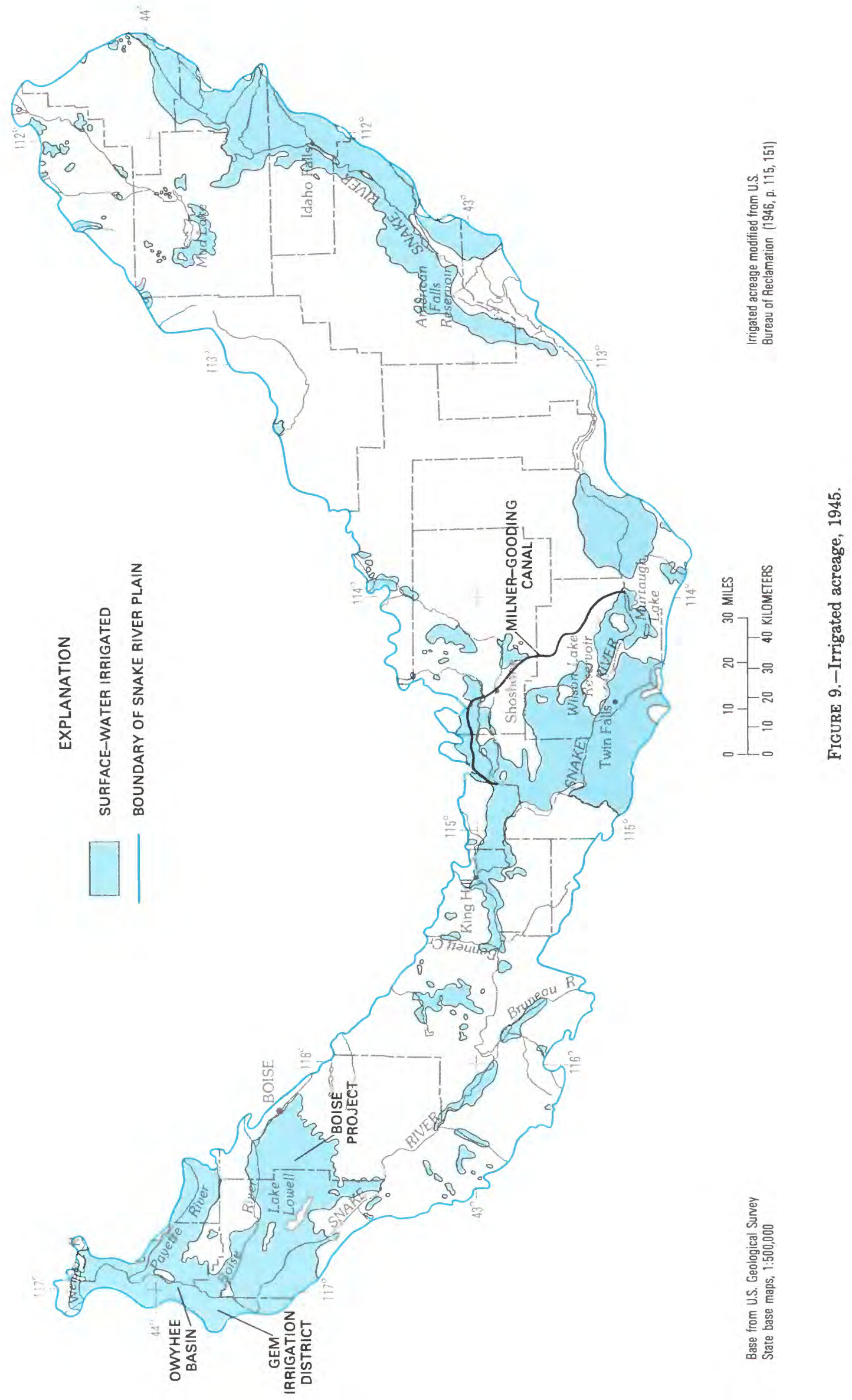
(Stearns and others, 1939, p. 106), but most pre-World War II irrigation was with surface water. After 1945, ground-water pumpage in the Mud Lake area increased steadily.

The Bureau of Reclamation's Minidoka Project was the first Federal project in Idaho to use both surface and ground water for irrigation. Beginning in 1947, about 65,000 acres (IDWR, 1978, Minidoka County) of the North Side Pumping Division eventually were supplied with water from more than 175 wells (Burnham and others, 1966, p. 28).

The 1950's and early 1960's were a period of rapid ground-water development. Wells were drilled to lower water levels in waterlogged areas and to provide a supplemental supply of irrigation water. Large ground-waterirrigated tracts were developed near Osgood, north of American Falls Reservoir, and in Cassia County. By 1966, about 700,000 acres on the Snake River Plain were irrigated with ground water and about 2.5 million acres were irrigated with surface water (fig. 10).

Since the 1960's, annual increases in irrigated acreage on the Snake River Plain have declined, and total irrigated area has stabilized at about 3 million acres. However, irrigation practices have continued to change, and irrigation with ground water and with surface water pumped from deeply entrenched river reaches has increased.

Ground water has been developed to irrigate new areas near Mud Lake and in Cassia County. In other places, inadequate surface-water supplies have been supplemented with ground-water pumpage (conjunctive use). A study by Bigelow and others (1984) indicates that the extent of conjunctive-use areas may be underestimated.

High-lift pumping from deeply entrenched reaches of the Snake River is a recent development; early surfacewater diversions were by gravity. From 1965 to 1975 , the volume of water pumped from the Snake River increased about eightfold (Bigelow and others, 1984). By 1980, pumped withdrawals accounted for about 90 percent of diversions from the Snake River below Milner.

Increasing power rates in the 1970's made more efficient use of water an economic necessity. Accordingly, use of center pivot and other types of sprinkler distribution systems increased.

\section{METHODS OF ESTIMATING IRRIGATION WATER USE}

To best describe water use for irrigation on the Snake River Plain, withdrawals and consumptive use were estimated for both surface and ground water. Surface water is withdrawn by pumps and gravity diversions. Pumped withdrawals from surface and ground water were estimated from data on power consumed by irriga- tion pumps. Most gravity diversions were measured by State or irrigation district personnel. Consumptive use was estimated from data on irrigated acreage and crop evapotranspiration rates.

\section{PUMPED WITHDRAWALS OF SURFACE AND GROUND WATER FOR IRRIGATION}

Pumped withdrawals of surface and ground water on the Snake River Plain are seldom metered, and it is impractical to do so for 5,300 wells and 620 river pumping stations. Pumpage was estimated from electrical power consumption data because nearly all pumps on the Snake River Plain are electrically powered, the method is efficient for a large number of sites, and power data were available from utility companies. Young and Harenberg (1971, p. 11) determined that fewer than 1 percent of the irrigation wells on the eastern plain were equipped with nonelectric pumps. Field observation confirmed that there are few nonelectric irrigation pumps on the eastern and western plain.

Power consumed by a pump to lift and deliver water is related to total head (head from lift and from pressurized distribution systems) and quantity of water pumped. Expressed mathematically,

$$
k W h=(T H)(Q)(K)
$$

where

$k W h$ is total power consumed in a year, in kilowatthours;

TH is total head, in feet, which, in turn, equals pumping lift (the distance from land surface to pumping water level), $H_{L}$, plus the pressure head associated with the irrigation distribution system, $H_{P}$;

Q is total volume of water pumped in a year, in acre-feet; and

$K \quad$ is number of kilowatthours required to lift 1 acre-ft of water $1 \mathrm{ft}$, in kilowatthours per acre-ft-foot.

The annual volume of pumpage from individual pumping stations can be calculated by the following equation:

$$
Q=(k W h) /[(K)(T H)]
$$

\section{PUMPAGE CALCULATIONS}

Using equation 2, 1980 pumpage was calculated for each electrically powered irrigation well and river pumping station on the plain. Data on power consumed in 1980 by each pump were supplied by utility companies. The value of $K$ was estimated statistically on the basis of field test 


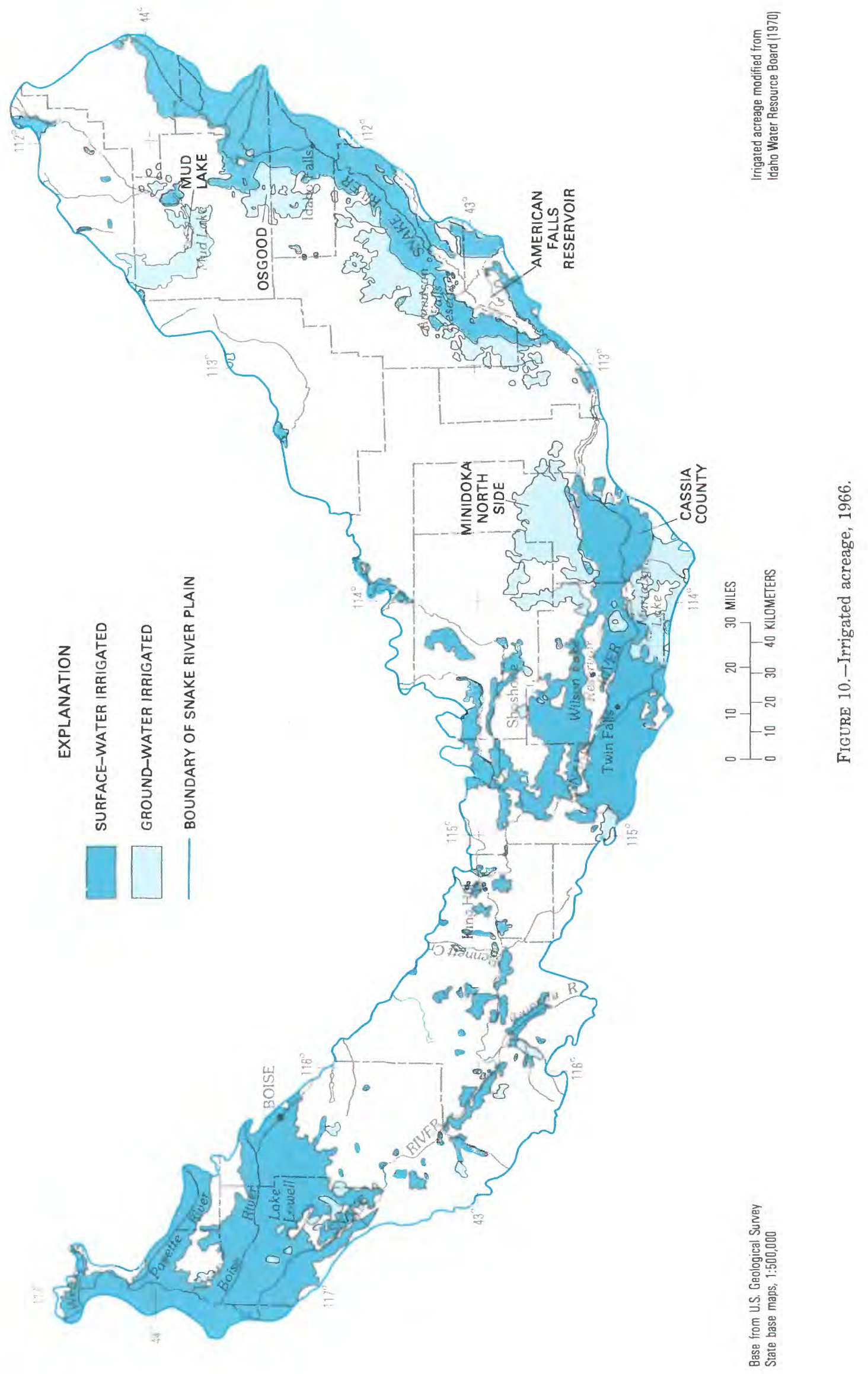


data. Total head for each pump $\left(H_{L}\right.$ plus $\left.H_{P}\right)$ was estimated from water-level data and type of distribution system.

Withdrawals from wells were summed over areas of 15 minutes latitude by 15 minutes longitude that correspond to U.S. Geological Survey 1:62,500 topographic maps. Withdrawals by river pumps on the Snake River and its major tributaries were summed between U.S. Geological Survey gaging stations.

The value of $K$ was estimated from 79 field tests. Volume discharged (acre-feet), power consumed (kilowatthours), and total head (feet) were measured during short tests (20-30 minutes) at 72 wells and 7 river pumps to determine site-specific values of $K$. Test values of $K$ are shown in figure 11. A representative value of $K$, subsequently used as a constant in pumpage calculations, was estimated by linear regression of the data (fig. 11). The estimated value of $K$ is the slope of the regression line. On the basis of sample data shown in figure $11, K$ equals 1.69 ; that is, $1.69 \mathrm{kWh}$ were used to lift 1 acre-ft of water $1 \mathrm{ft}$.

Total head was estimated for each well and river pump by summing estimates of pumping lift and pressure head. Pumping lift for wells includes static lift and pumping drawdown. Static lift is the difference between altitude of land surface at the point of discharge and altitude of prepumping water level. Land-surface altitudes were interpolated from topographic maps, and prepumping water levels were interpolated from the March 1980 water-table map (Lindholm and others, 1983).

A pumping drawdown of $56 \mathrm{ft}$ was added to estimated static lift for all wells on the western plain and $6 \mathrm{ft}$ for all wells on the eastern plain. Drawdowns are medians from data reported by well drillers for wells yielding more than $300 \mathrm{gal} / \mathrm{min}$ (fig. 12). Medians rather than means were used to dampen the effects of a few reported extremely high drawdowns.

Differences in drawdown estimates for the eastern and western plain are due largely to differences in aquifer transmissivity. Most wells on the eastern plain are completed in high water-yielding basaltic rocks, whereas most wells on the western plain are completed in relatively low water-yielding sedimentary rocks.

Pumping lift for river pumps is the difference between altitude of land surface at the point of discharge and altitude of river stage. Locations of river pumps were verified in the field, then plotted on topographic maps to determine land-surface and river-stage altitudes.

Pressure head $\left(H_{P}\right)$ at wells and river pumps was estimated on the basis of type of distribution system as reported by utilities. Types of distribution systems supplied by river pumps were verified in the field.

Heads for center pivot and other sprinkler systems are averages of pressure estimates reported in a survey of companies that sell and install irrigation systems in the study area. The estimates are shown in the following table.

\begin{tabular}{lcc}
\hline \multirow{2}{*}{$\begin{array}{c}\text { Irrigation } \\
\text { distribution } \\
\text { system }\end{array}$} & \multicolumn{2}{c}{ Estimated pressure head } \\
\cline { 2 - 3 } & lb/in ${ }^{2}$ & feet \\
\hline Gravity & 0 & 0 \\
Sprinkler, center pivot & 90 & 208 \\
Sprinkler, other & 60 & 139 \\
\hline
\end{tabular}

\section{ACCURACY OF ESTIMATED PUMPAGE}

The most common method for estimating pumpage from power consumption data is to divide total kilowatthours

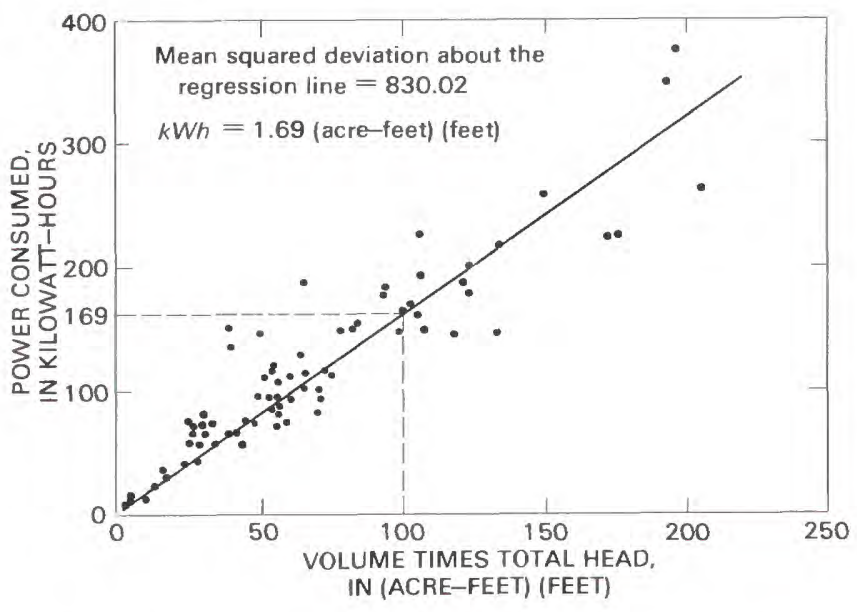

FIGURE 11.-Relation between power consumed and volume of water pumped times total head.

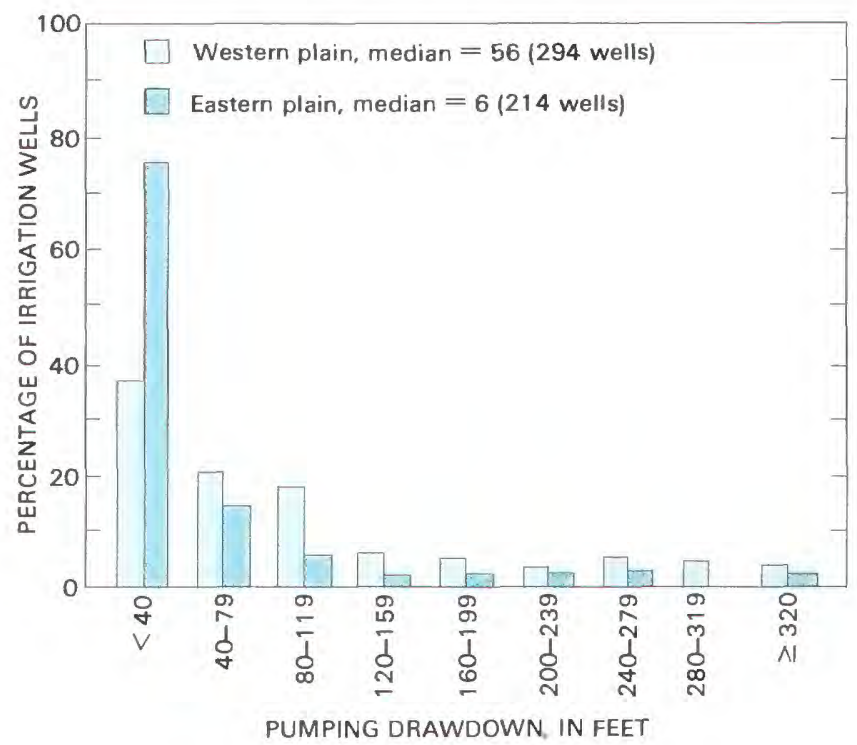

FIGURE 12.-Estimated well drawdowns. 
consumed by the average number of kilowatthours required to withdraw 1 acre-ft of water. The method used in this study differs in its site-specific consideration of total head. Variation in total head causes variation in the amount of power needed to pump 1 acre-ft of water; pumps with high lifts supplying pressurized sprinkler systems consume more power per acre-foot of water withdrawn than pumps with low lifts supplying gravity distribution systems. Pumping lifts and types of distribution systems, and thus total head, on the Snake River Plain vary widely. The estimation method used, in which total head is estimated for each pumping station, provides reasonable pumpage estimates and permits spatial distribution of total aquifer stress from pumping.

Tests of the accuracy of pumpage estimates indicate the estimated pumpages are reasonably reliable. However, because this approach has not been used broadly, it is important that the accuracy of pumpage estimates be evaluated. Errors introduced by the study method are difficult to quantify, but a general discussion of potential errors and their effects will aid interpretation of the accuracy of the estimates. Most errors are introduced in the estimation of $K$ and total head.

\section{The Constant $K$}

In pumpage calculations, $K$ is treated as a constant, whereas in the population of pumping stations, $K$ is variable owing to differences in pump efficiencies. At 100 percent efficiency, $K$ equals $1.02 \mathrm{kWh} /$ acre-ft; that is, it takes just over 1 kilowatthour $(1 \mathrm{kWh}=2,655,240 \mathrm{ft}-\mathrm{lb} / \mathrm{h})$ to lift an acre-foot of water $(2,717,589 \mathrm{lb})$ by $1 \mathrm{ft}$. Actual values of $K$ are much higher owing to inefficiencies of irrigation pumps. The representative $K$ value of 1.69 obtained from sample data implies an average pump efficiency of 60 percent $(1.02 / 1.69 \times 100)$.

Measured efficiencies of the 79 pumping stations sampled ranged from 28 to 90 percent. About three-fourths were between 45 and 75 percent, and one-half were between 50 and 70 percent (fig. 13). Treating $K$, and thereby efficiency, as a constant in pumpage calculations introduces error into pumpage estimates for individual plants. However, if errors are randomly distributed, summing estimates for all pumping plants in an area ( 15 minutes longitude by 15 minutes latitude) or river reach reduces the errors by cancellation.

\section{Total Head}

Pumpage estimates calculated by the study method are sensitive to errors in the value of total head, particularly if total head is low. Table 5 shows pumping conditions at two hypothetical wells, one with low total head and one with high total head, and the errors in pumpage estimates that result from errors in estimated total head.
Note that (1) error in pumpage is inversely proportional to error in total head, (2) underestimation of total head causes greater error than overestimation, and (3) the effect of an error in estimated head is much greater when total head is small. Thus, pumpage estimates are more likely to be inaccurate where prepumping water levels are near land surface and drawdowns are small. Because total head is composed of pumping lift and irrigation system pressure head, errors in either component will cause errors in pumpage estimates.

To assess accuracy of estimated lifts used in pumpage calculations during the study, measured pumping lifts were compared to estimated lifts at 72 sample sites ( 7 of the 79 sites were not used because of imprecise lift measurements). The relation between estimated and measured lifts is shown in figure 14. A correlation coefficient of 0.89 for the linear regression between estimated and measured values indicates that estimated lifts are reasonable approximations of actual lifts within the confidence of the data.

Pressure-head estimates for each type of distribution system are reasonably accurate considering errors in pumping lift. Type of distribution system reported by utilities agreed with the type of system observed at 90 percent of the sample sites.

Errors in estimates of total head and $K$ combine to affect the accuracy of pumpage estimates. To test the combined effect, pumpage was estimated at the 79 sample sites using (1) measured pumping lift and $K$ values determined from field test data at each sampling site, and (2) estimated pumping lift and a $K$ value of $1.69 \mathrm{kWh} /$ acre$\mathrm{ft}$ of water per foot of lift, which is the average $K$ value resulting from all tests. Total pumpage was obtained by

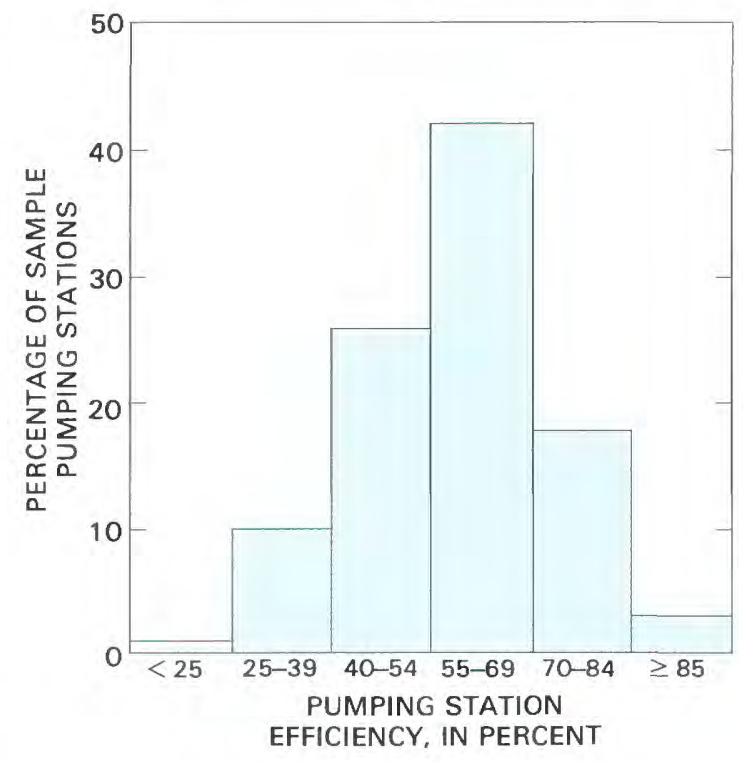

Figure 13.-Efficiencies of sample pumping stations. 
TABLE 5.-Errors in pumpage estimates owing to errors in estimates of total head at two hypothetical wells

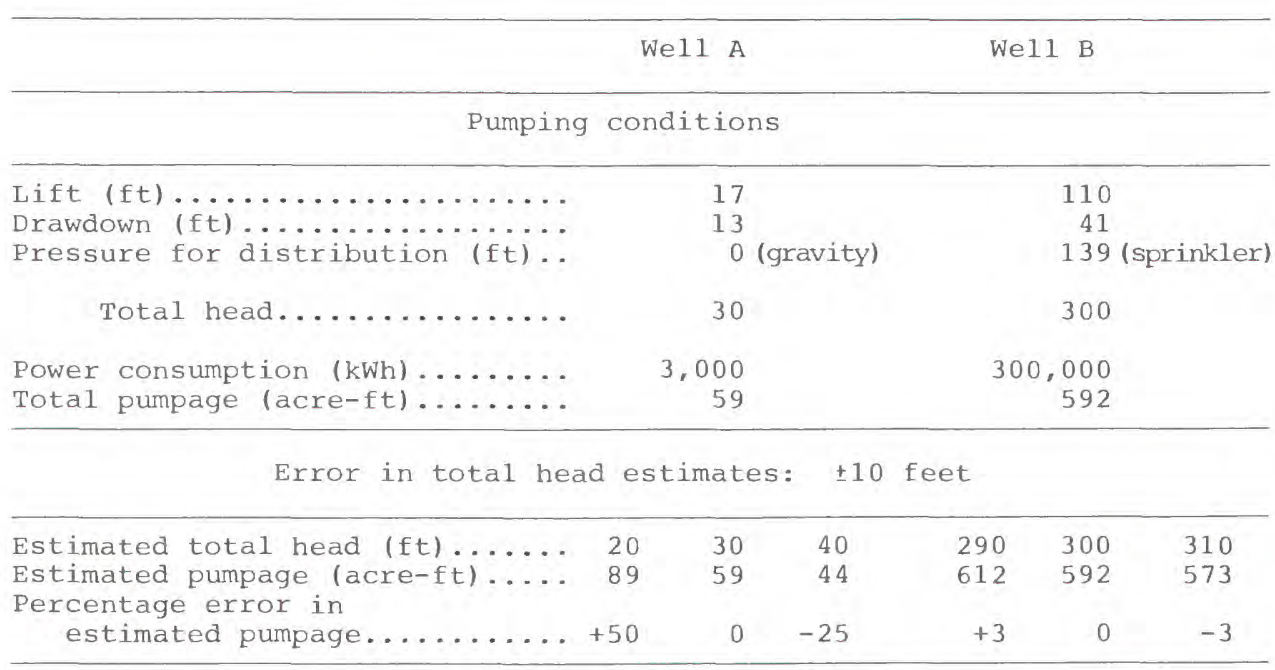

summing pumpage for all sample sites. Total pumpage estimated by the individual $K$ values determined from field tests was 1.3 percent greater than total pumpage estimated by the average $K$ value determined from all tests, even though differences for individual sample sites were greater than the cumulative difference. Results suggest that aggregation reduces the error of the estimates, because of the random distribution of the errors.

\section{GRAVITY WITHDRAWALS OF SURFACE WATER FOR IRRIGATION}

Most surface-water withdrawals for irrigation on the Snake River Plain are gravity diversions. Diversions from the Snake River and many tributaries are measured by watermasters serving irrigation districts and are reported annually. Gravity withdrawals in 1980 from the Snake River above Milner Dam and the Henrys Fork, Teton, Falls, Big Wood, Little Wood, Blackfoot, Boise, and Owyhee Rivers were obtained from watermaster reports. Gravity withdrawals from the Snake River below Milner Dam and from most other rivers were estimated from previous miscellaneous measurements.

\section{CROP CONSUMPTIVE IRRIGATION REQUIREMENT}

Crop consumptive use (CU) is the depth of water evapotranspired by a healthy, well-watered crop and evaporated from the soil during the growing season. Crop consumptive irrigation requirement (CIR) is that part of CU needs not satisfied by precipitation and thus supplied by irrigation. The required volume of irrigation water can be estimated by multiplying CIR times acres irrigated. The volume of irrigation water applied on the Snake River
Plain was estimated for each 15 -minute block using the following equation:

$$
T V=(\mathrm{CIR} \times I A) / 12
$$

where

$T V$ is total volume of irrigation water applied annually to crops in a block, in acre-feet per year;

CIR is average crop consumptive irrigation requirement, in inches per year; and

$I A$ is total irrigated area in a block, in acres.

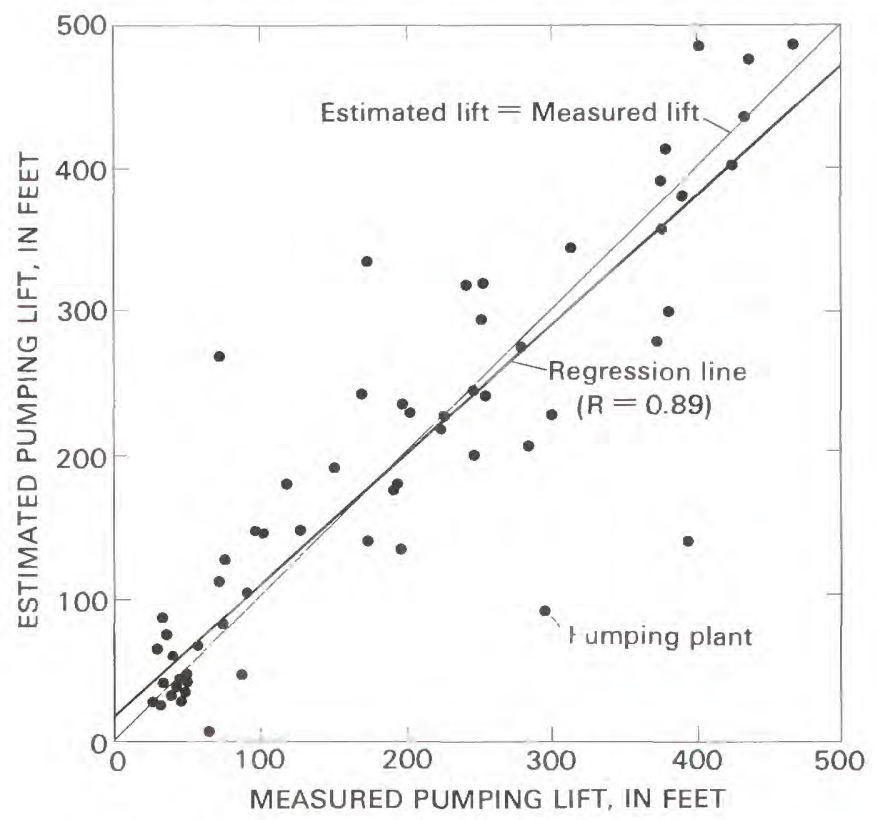

Figure 14.-Accuracy of estimated pumping lifts. 
Average values for CIR were assigned to each 15 -minute block based on crop-related CIR values determined by Sutter and Corey (1970). Sutter and Corey (1970) divided Idaho into 42 areas of similar climate and calculated CIR for crops commonly grown in each climatic area. The Snake River Plain partially or wholly comprises 17 of Sutter and Corey's climatic areas. If a 15-minute block fell into more than one climatic area, the CIR value assigned was that for the largest climatic area in the block. The CIR assigned to each block is the average of all croprelated CIR's calculated for the climatic area. Values for CIR range from $22.9 \mathrm{in} . / \mathrm{yr}$ near Grand View to $11.6 \mathrm{in} . / \mathrm{yr}$ near Ashton (table 6).

Acreages irrigated with ground water and combined surface and ground water in each block were digitized from a map of 1979 irrigated acreage. In areas supplied by combined surface and ground water, an unknown part of CIR is from surface water. To account for the part of CIR supplied by surface water only, half of the acreage irrigated with combined surface and ground water was assumed to be supplied by ground water.

TABLE 6.-Average crop consumptive irrigation requirements recorded at selected weather stations

[Modified from Sutter and Corey (1970)]

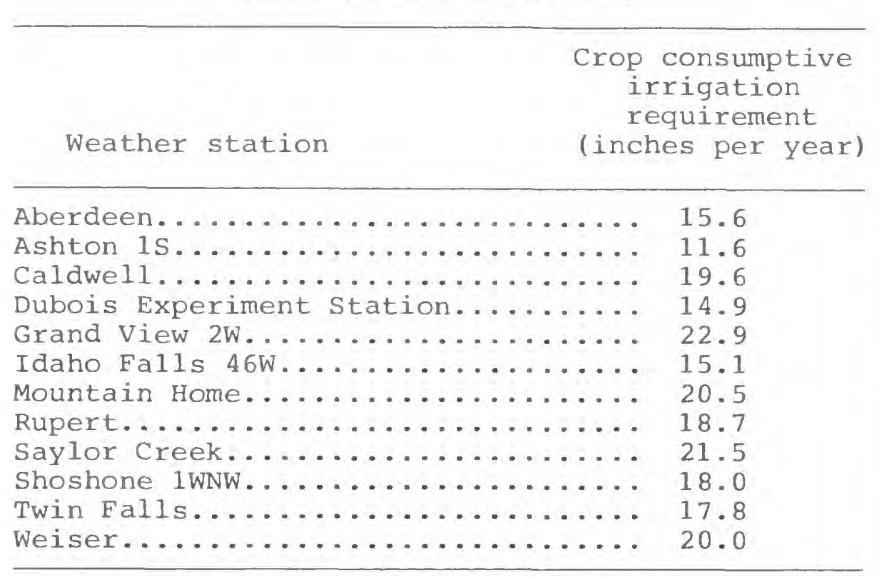

\section{SURFACE-WATER IRRIGATION, 1980}

Until the 1960's, almost all surface water used for irrigation was diverted by gravity. Beginning in about 1960, pumping from surface-water sources became more common. By 1980, two-thirds of the irrigated area on the Snake River Plain was supplied by surface water, mostly by gravity diversions. An estimated 11.8 million acre-ft was diverted by gravity and conveyed by $2,700 \mathrm{mi}$ of canals and laterals. Locations of major canals on the plain are shown in figure 15 . About 6.9 million acre-ft was diverted from the Snake River and 4.9 million acre-ft from major tributaries. An additional 940,000 acre-ft was withdrawn by river pumps: 808,000 acre-ft from the Snake River and 132,000 acre-ft from tributaries. More than 9 million acre-ft of instream reservoir capacity makes water available during low-flow months.

Gravity diversions are concentrated on the eastern part of the plain and in the Boise and Payette River basins where rivers are not deeply entrenched. In the central part of the plain (Milner to Murphy) where rivers are deeply entrenched, irrigation water is either lifted by river pumps or diverted into large canals at higher river altitudes some distance upstream.

Figure 16 shows altitude of the Snake River with respect to land surface. More than 98 percent of gravity diversions from the Snake River are located above Milner, where river altitude is within $100 \mathrm{ft}$ of the adjacent land surface. Only 2 percent of total irrigation withdrawals in the Heise-to-Milner reach are pumped. Most pumping stations are small (less than $500 \mathrm{hp}$ ) and supply water to lands close to the river.

Below Milner, 90 percent of irrigation withdrawals from the Snake River are pumped. From Milner to Hagerman (about $70 \mathrm{mi}$ ), the river is entrenched in a sharply incised canyon, and almost all withdrawals are by large pumps that supply water to lands close to the canyon rim. Large pumping stations typically have several pumps that feed one or more penstocks that discharge into a canal system on the canyon rim. The largest pumping station has 15 pumps powered by motors totaling $21,000 \mathrm{hp}$.

Surface-water-irrigated lands in the Twin Falls and Minidoka Project areas, as much as $20 \mathrm{mi}$ from the Snake River, are supplied by canals that divert water above Milner. In 1980, 2.9 million acre-ft was diverted to five canals at Milner and Minidoka Dams to irrigate these lands.

From Hagerman to near Homedale (about $160 \mathrm{mi}$ ), the river is entrenched several hundred feet, but the canyon bottom is several miles wide in some places. Water is withdrawn along this reach by large, high-lift pumps that supply water to tracts on the canyon rim and by smaller pumps that supply water to canyon bottom lands.

Below Homedale, the Snake River is entrenched from 10 to $50 \mathrm{ft}$, and all irrigation water is pumped. Typical pumping stations in this reach irrigate small tracts close to the river. About 94 percent of pumping stations below Homedale are smaller than $100 \mathrm{hp}, 93$ percent have lifts less than $50 \mathrm{ft}$, and 76 percent discharge to gravity distribution systems.

Table 7 is a summary of 1980 surface-water diversions from the Snake River and its major tributaries for irrigation on the plain.

In 1980, estimated CU in surface-water-irrigated areas on the Snake River Plain was about 4.1 million acre-ft. This is the approximate volume of water needed to satisfy crop evapotranspiration requirements in an average year. 


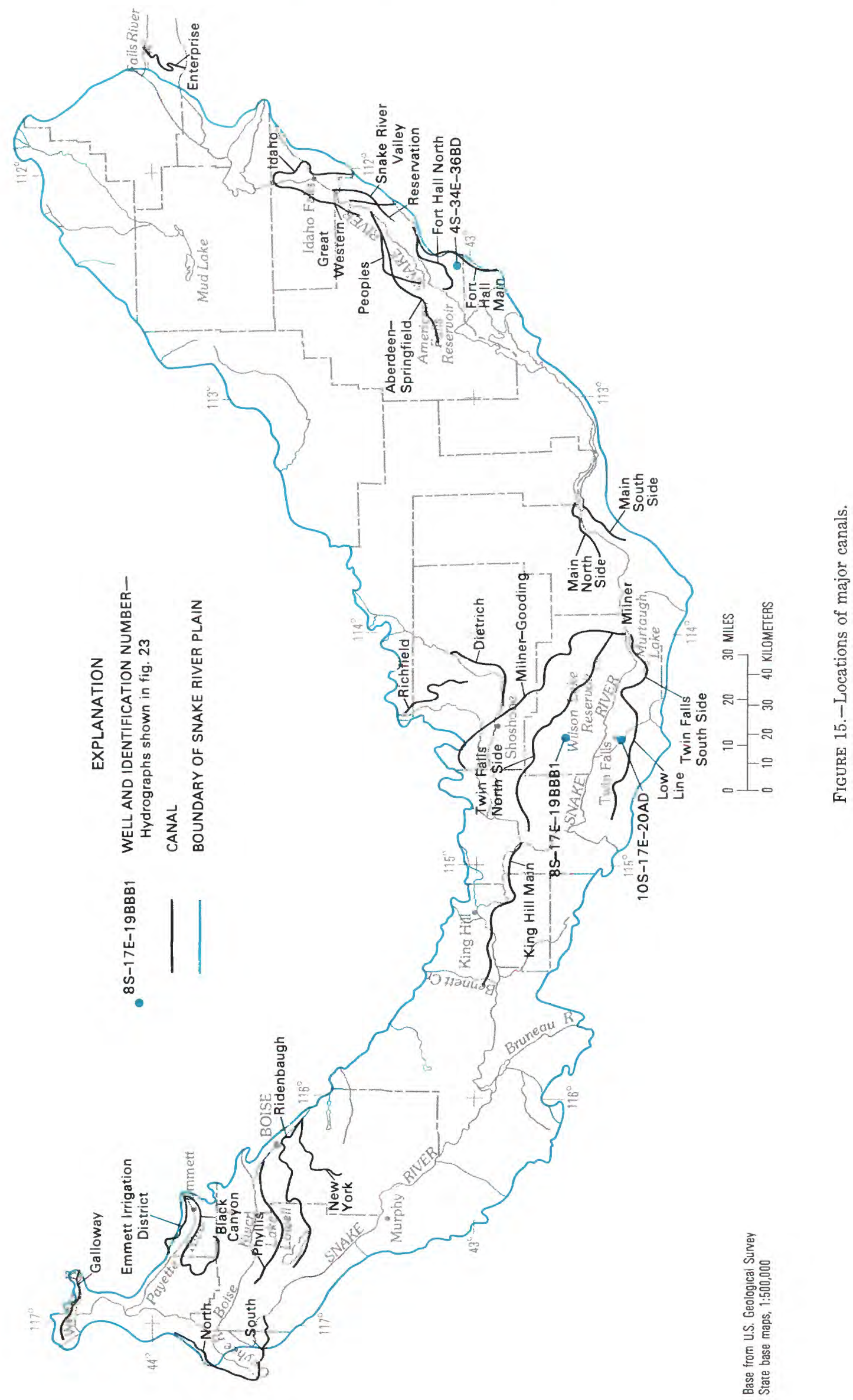


Part of the water is supplied by precipitation, but most, the CIR, is supplied by irrigation. Estimated CIR for surface-water-irrigated areas on the plain is about 3.5 million acre-ft. Of the 12.7 million acre-ft of surface water withdrawn, about 3.5 million acre-ft is evapotranspired by crops. The rest evaporates from canal surfaces, remains in the soil, infiltrates to ground water, or returns to streams. High losses in surface-water-irrigated areas probably are due to high application rates in floodirrigated fields and to large canal losses. Some of the larger canals transport water to irrigated areas several tens of miles from points of diversion, incurring losses along their entire length.

\section{GROUND-WATER IRRIGATION, 1980}

In 1980 , about 1.0 million acres were irrigated with ground water, and at least 0.1 million acres were irrigated with a combination of surface and ground water. Of the estimated 2.3 million acre-ft of ground water pumped, 1.93 million acre-ft was withdrawn on the eastern plain and 0.36 million acre-ft was withdrawn on the western plain. The quantities and locations of ground-water withdrawals on the Snake River Plain are shown in figure 17. More detailed maps of ground-water withdrawals and electrical power consumption for irrigation are presented by Bigelow and others (1984).

Irrigation wells on the Snake River Plain are characterized in table 8 on the basis of a sample of 940 drillers' logs. The sample was limited to irrigation wells by eliminating wells discharging less than $300 \mathrm{gal} / \mathrm{min}$.

Most irrigation wells on the Snake River Plain are completed in basaltic and sedimentary rocks; a few are completed in rhyolite (fig. 18). On the eastern plain, most water is from fractured zones between successive basalt flows. Sedimentary rocks are principal aquifers along the periphery of the eastern plain, east of American Falls Reservoir, and in the Big Lost River, Portneuf River, and Camas Creek basins (fig. 3). On the western plain, most irrigation wells are completed in unconsolidated sedimentary rocks, especially in the Boise River valley. Basalts are principal aquifers in the Mountain Home area.

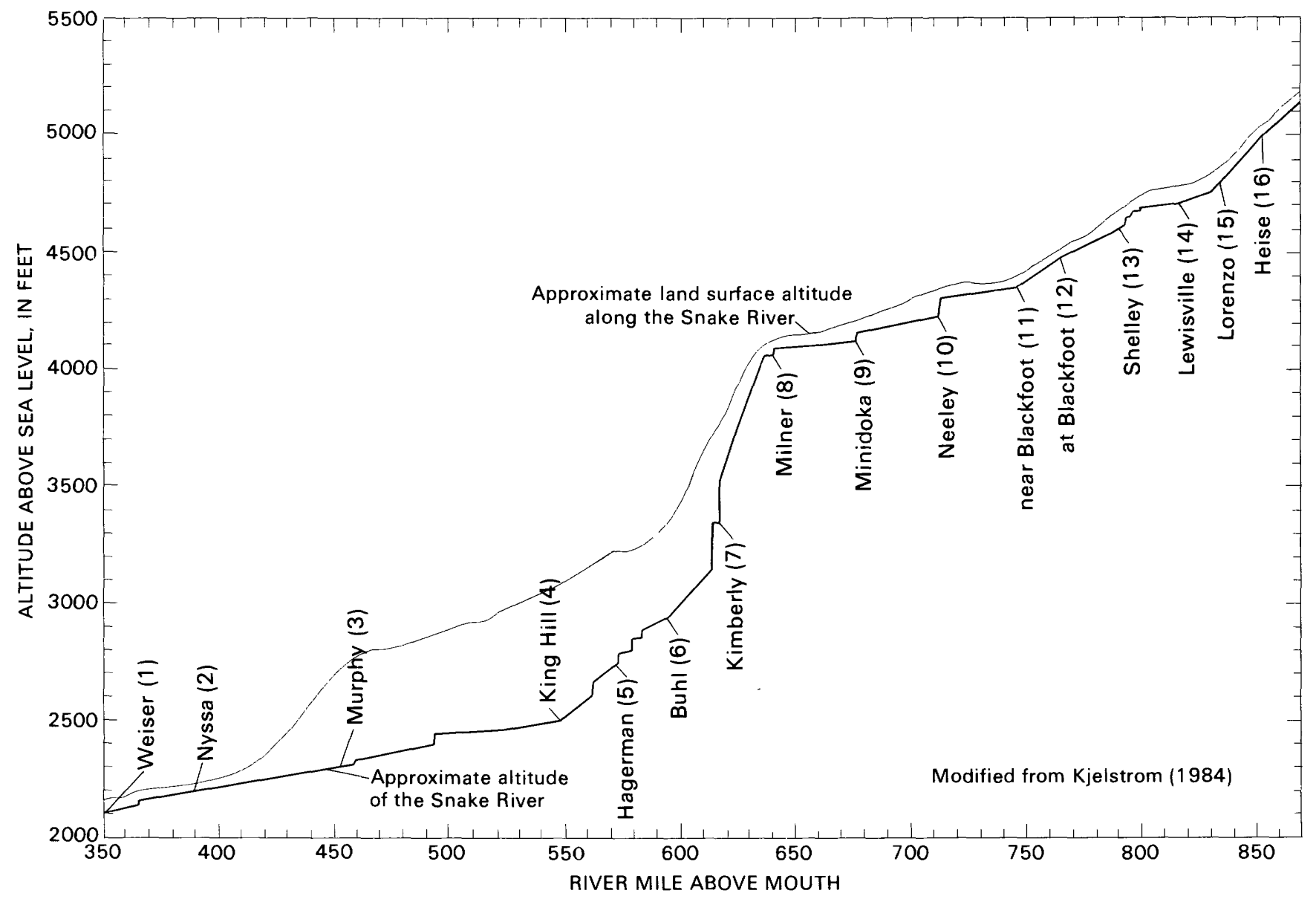

FIguRE 16.-Altitude of Snake River and adjacent land surface. 


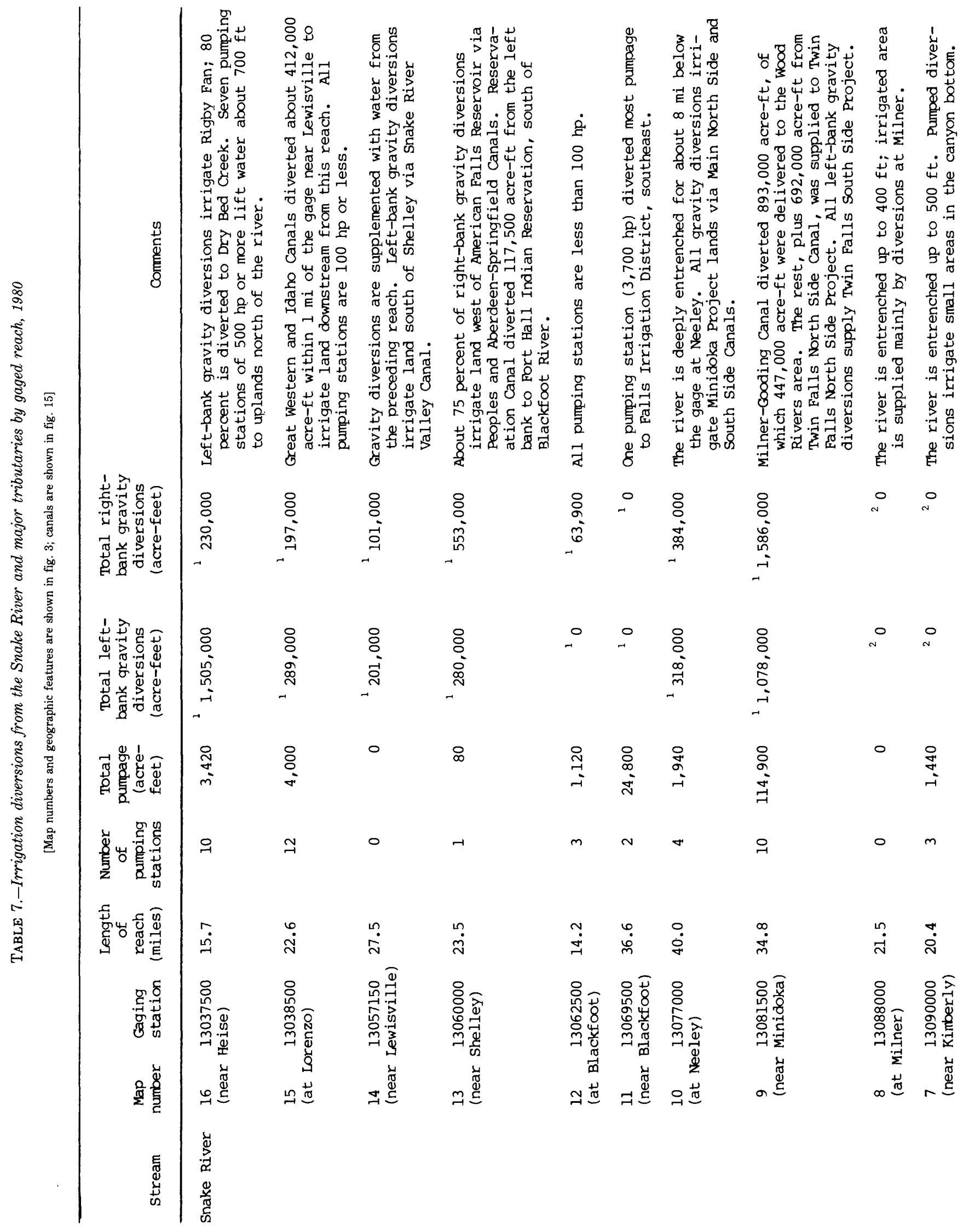


WATER USE ON THE SNAKE RIVER PLAIN

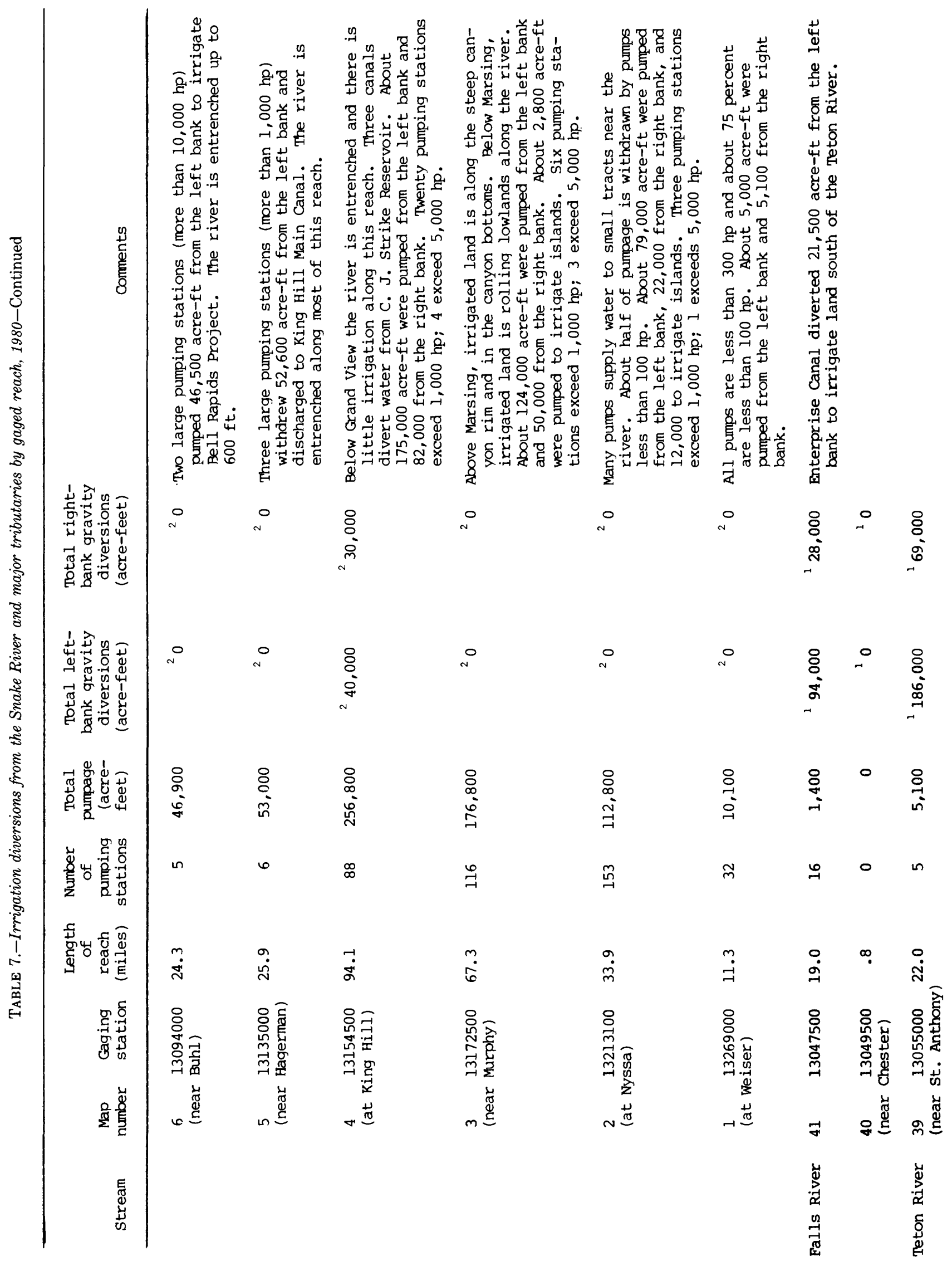




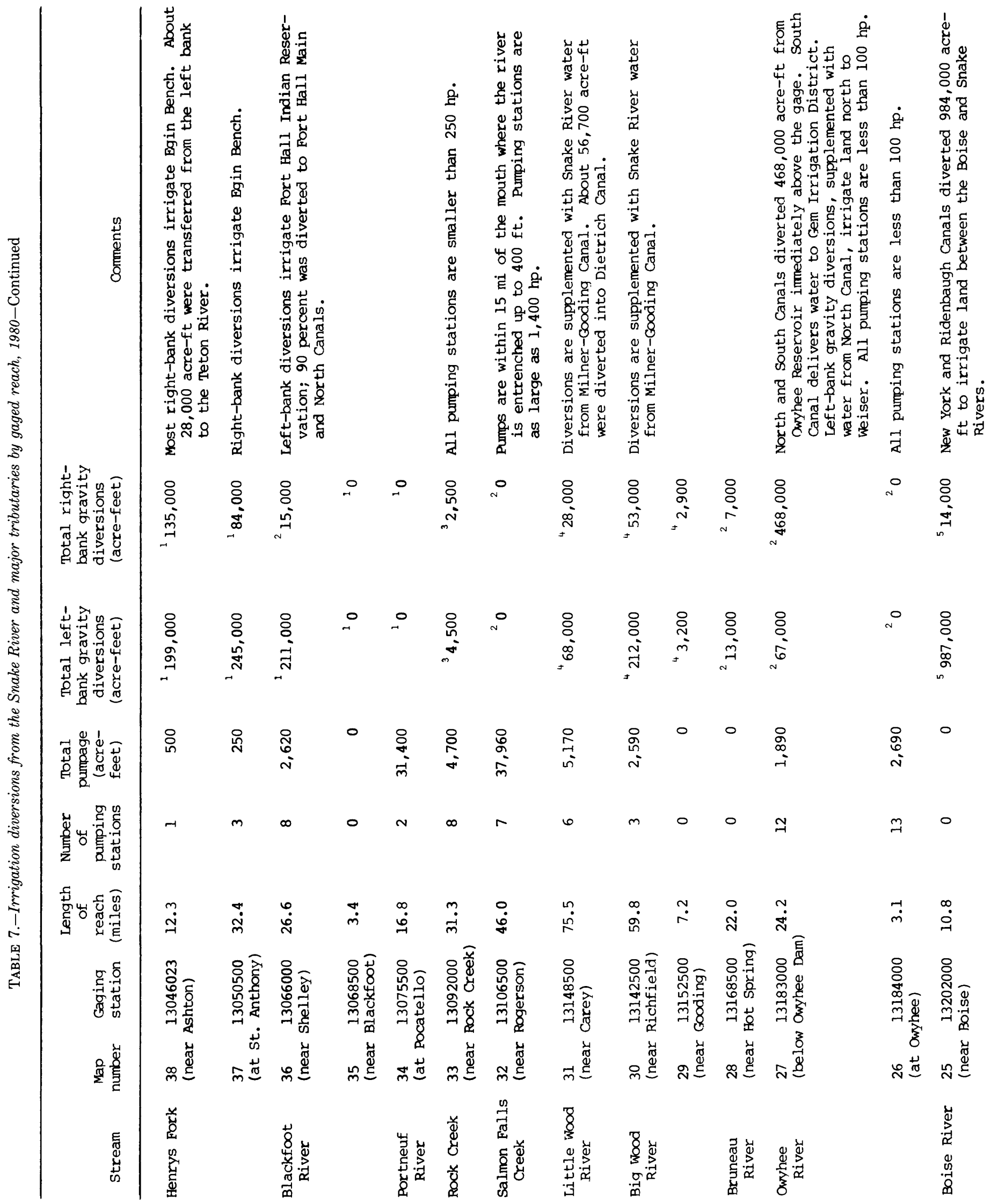


WATER USE ON THE SNAKE RIVER PLAIN

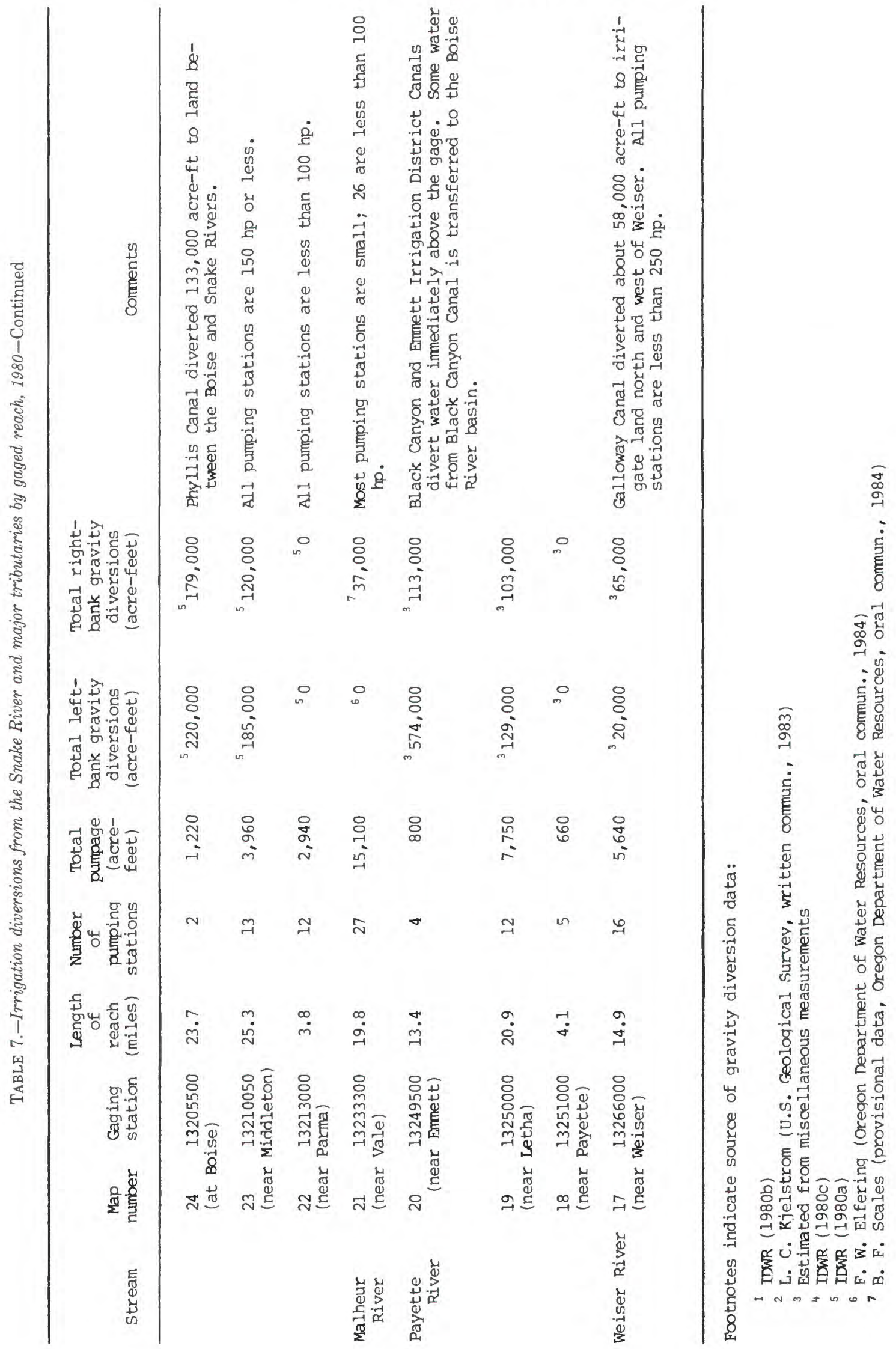




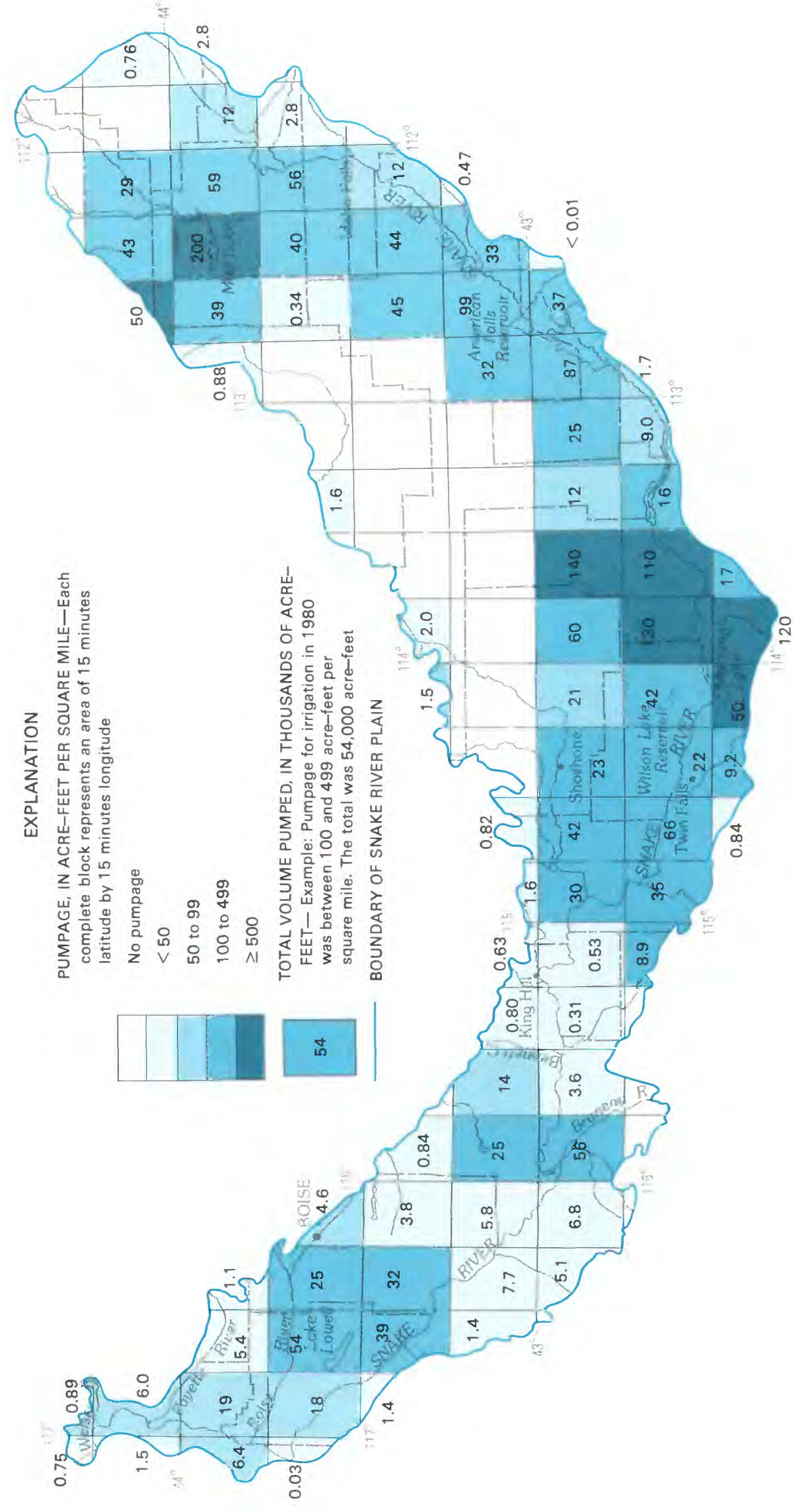

要 
WATER USE ON THE SNAKE RIVER PLAIN

TABLE 8.-Characteristics of irrigation wells

\begin{tabular}{|c|c|c|c|c|}
\hline Characteristics & Eastern & plain & Western & plain \\
\hline $\begin{array}{l}\text { Lithology of producing } \\
\text { zone }\end{array}$ & Basalt & Sediment & Basalt & Sediment \\
\hline $\begin{array}{l}\text { Number of wells in } \\
\text { sample }\end{array}$ & 336 & 60 & 120 & 424 \\
\hline Well finish & Open hole & $\begin{array}{l}\text { Cased and } \\
\text { screened or } \\
\text { perforated }\end{array}$ & Open hole & $\begin{array}{l}\text { Cased and } \\
\text { screened or } \\
\text { perforated }\end{array}$ \\
\hline $\begin{array}{l}\text { Percentage of wells } \\
\text { yielding at least } \\
1,500 \text { gallons per } \\
\text { minute }\end{array}$ & 66 & 64 & 78 & 32 \\
\hline $\begin{array}{l}\text { Maximum reported } \\
\text { vield, in gallons } \\
\text { per minute }\end{array}$ & 7,240 & 3,000 & 5,000 & 3,850 \\
\hline $\begin{array}{l}\text { Percentage of wells } \\
\text { with drawdowns } \\
\text { less than } 20 \mathrm{ft}\end{array}$ & 68 & 45 & 20 & 22 \\
\hline
\end{tabular}

Typically, wells on the eastern plain have larger yields (fig. 19) and lower drawdowns than wells on the western plain, owing to the copious water-producing properties of basalt. About 66 percent of wells on the eastern plain yield more than $1,500 \mathrm{gal} / \mathrm{min}$, and median pumping drawdown is $6 \mathrm{ft}$. On the western plain, 42 percent of wells yield more than $1,500 \mathrm{gal} / \mathrm{min}$, and median pumping drawdown is $56 \mathrm{ft}$.

Well depths range from less than $100 \mathrm{ft}$ to more than 2,000 ft. Most wells on the Snake River Plain are located where depth to water is less than $300 \mathrm{ft}$. Generally, water is closest to land surface along the Snake River and its tributaries and in areas with a history of surface-water irrigation (fig. 20). Excess irrigation water has caused historic rises in ground-water levels in most surfacewater-irrigated areas.

The horsepower of pumps and types of irrigation distribution systems on the plain were determined from data supplied by power companies or were observed in the field. Ninety-six percent of wells are equipped with pumps totaling less than $500 \mathrm{hp}$ and 39 percent with pumps totaling less than $100 \mathrm{hp}$. Most pumps with less than $100 \mathrm{hp}$ have low lifts and supply gravity distribution systems.

Types of distribution systems supplied by wells in 1980 were: 29 percent gravity, 13 percent center pivot sprinkler, and 58 percent other types of sprinkler. Gravity systems are more common on the western plain, and center pivot systems are more common on the eastern plain. An area irrigated by sprinklers typically uses less water per acre than if irrigated by gravity distribution.
Thus, in recent years, as pumping costs increased, the percentage of wells supplying sprinkler systems increased.

Estimated pumping lifts (static lift plus pumping drawdown) were less than $200 \mathrm{ft}$ in 65 percent of irrigation wells on the plain and less than $300 \mathrm{ft}$ in 85 percent of the wells. In a few areas where ground-water levels are declining, pumping lifts are approaching $500 \mathrm{ft}$.

More than 80 percent of ground-water pumpage for irrigation on the Snake River Plain occurs on the eastern part. After World War II, when ground-water pumping became economically feasible, most surface water on the eastern plain had long been appropriated. Ground water was the logical source of supply for new irrigated acreage. By 1980 , about 4,030 wells were pumped for irrigation on the eastern plain. Ground-water pumping is concentrated around Mud Lake and Osgood, west of American Falls Reservoir and Blackfoot, in Cassia County, and in the Minidoka Project area. About 60 percent of the wells on the eastern plain are located in these areas; collectively, they account for about 70 percent of ground-water withdrawals.

Use of ground water for irrigation started early in the Mud Lake area because the water table was shallow (6 to $75 \mathrm{ft}$ below land surface) and pumping was economical. Most irrigation wells in the Mud Lake area are completed in the regional Snake Plain aquifer; a few are completed in a shallow alluvial aquifer overlying the regional aquifer system. In 1980, about 140,000 acres were irrigated with ground water or combined surface and ground water (Johnson and others, 1982, p. 49); 60 percent of the irri- 
gated area was supplied by canal companies that depend primarily on ground water. Estimated 1980 pumpage in the Mud Lake area was about 350,000 acre-ft.

The area around Osgood, northwest of Idaho Falls in Bonneville and Jefferson Counties, is irrigated with ground water from privately developed wells. Most were

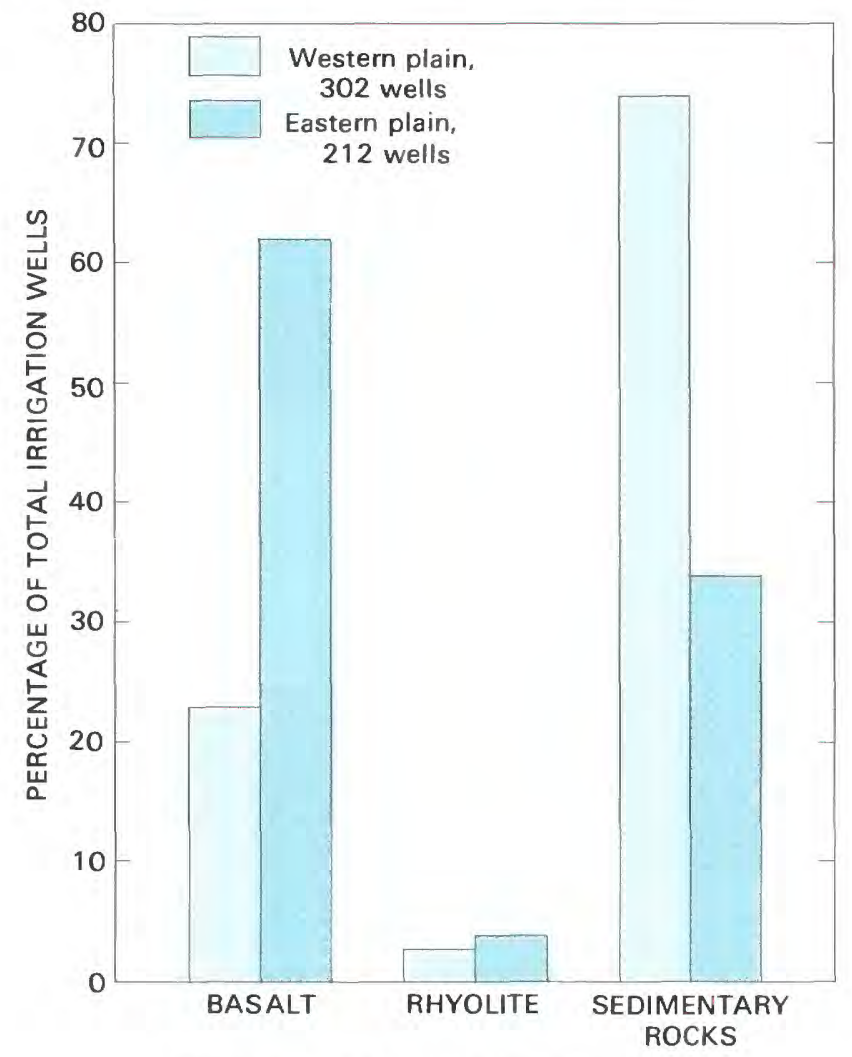

Figure 18.-Well completion by rock type.

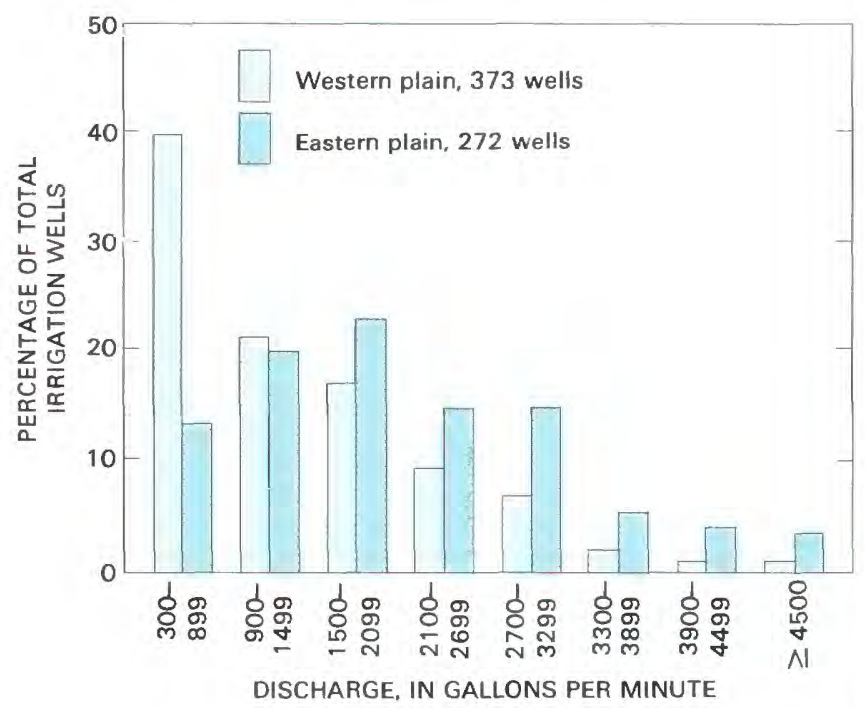

Figure 19.-Discharge from irrigation wells. drilled in the 1960's and 1970's when farmers converted from nonirrigated to irrigated agriculture. By 1980 , 230 wells supplied an estimated 91,000 acre-ft of water to 80,000 acres. With few exceptions, irrigation wells in the Osgood area are completed in basalt of the Snake River Plain aquifer.

Wells in ground-water-irrigated areas west of American Falls Reservoir and Blackfoot were privately developed after World War II, on lands a few tens of feet higher than surface-water-irrigated lands along the river. In the 1950 's and 1960 's, many wells were drilled to irrigate new land and lands previously irrigated with surface water. Most irrigation wells in these areas are completed in Quaternary basalt of the Snake River Group; a few near American Falls Reservoir are completed in coarse-grained alluvial deposits. Wells completed in basalt are generally 200 to $300 \mathrm{ft}$ deep, and water levels are 50 to $200 \mathrm{ft}$ below land surface. In 1980, an estimated 290,000 acre-ft of water was pumped from 1,005 irrigation wells in this area.

Ground-water-irrigated areas in Cassia County and eastern Twin Falls County roughly correspond to the Oakley-Kenyon, Cottonwood, West Oakley Fan, and Artesian City Critical Ground-Water Areas, as designated by the IDWR (fig. 21). Between 1967 and 1982, these areas were closed to further irrigation development because overpumping of ground water caused severe water-level declines. Most wells in Cassia and eastern Twin Falls Counties are completed in Quaternary basalt of the Snake River Group and Tertiary silicic Idavada Volcanics. Limestones and alluvium also yield water to irrigation wells locally. Well depths vary to more than $2,000 \mathrm{ft}$, and water levels in most wells are 200 to $500 \mathrm{ft}$ below land surface. In 1980, an estimated 185,000 acre-ft of irrigation water was withdrawn from 384 wells in this area.

In 1947, the U.S. Bureau of Reclamation began developing ground water as the supply for new irrigated acreage in the Minidoka Project. Eventually, about 62,000 acres were irrigated from wells in the North Side Pumping Division. In the 1950's and 1960's, ground water was privately developed as the supply for another 60,000 acres north of the Minidoka Project. Most irrigation wells in the Minidoka area are completed in Quaternary basalt of the Snake River Group. Typical wells are 200 to $300 \mathrm{ft}$ deep, and depth to water is 150 to $250 \mathrm{ft}$. In 1980, an estimated 390,000 acre-ft of water was withdrawn from 500 wells to irrigate lands in Minidoka and adjacent counties.

Another 1,500 irrigation wells are scattered across the eastern plain in smaller ground-water-irrigated areas. More than 300 of them are interspersed in surface-waterirrigated areas in Jerome and Gooding Counties and are used to supplement the surface-water supplies. The rest are adjacent to or within other surface-water-irrigated areas on the eastern plain. 

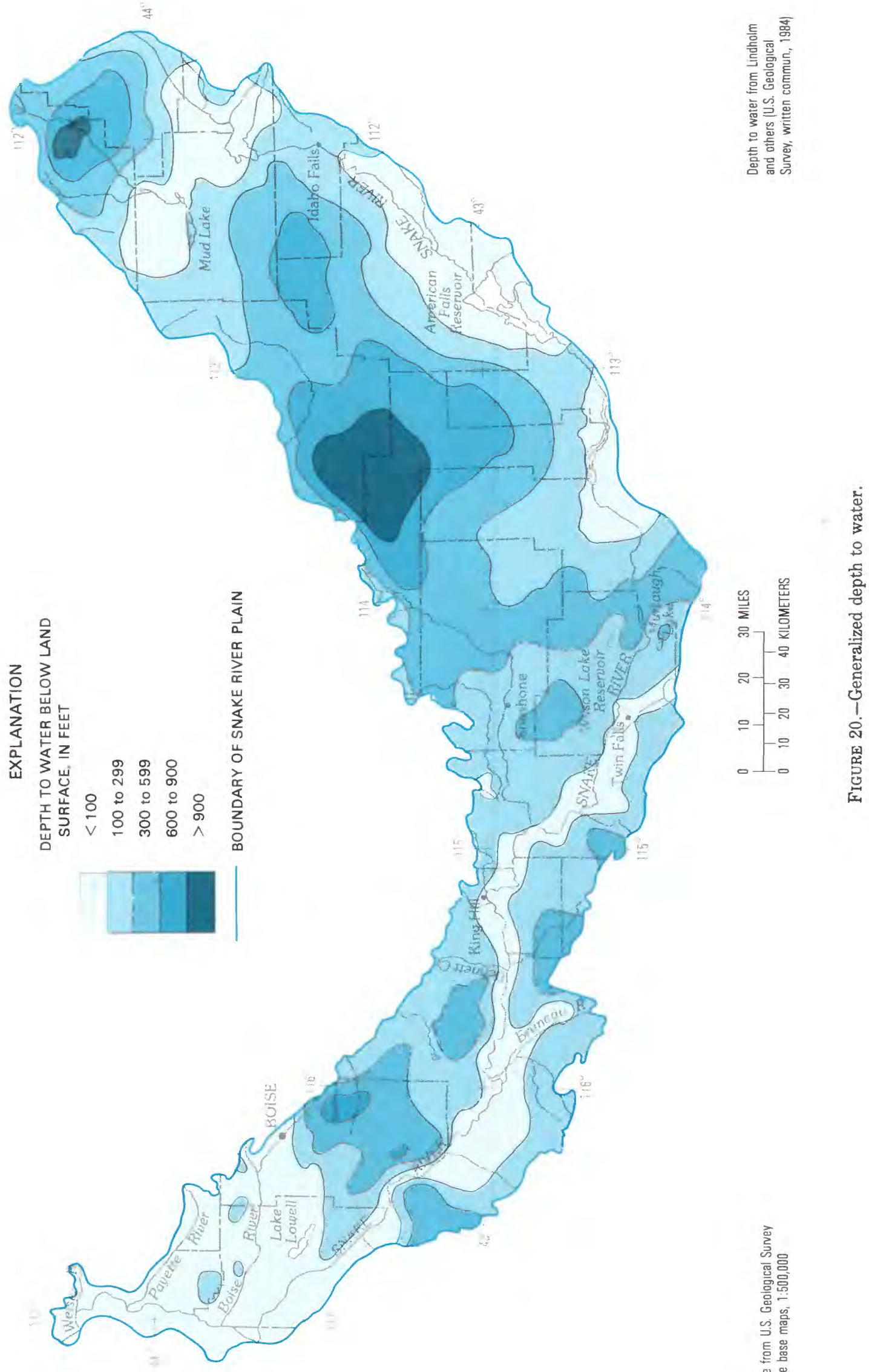


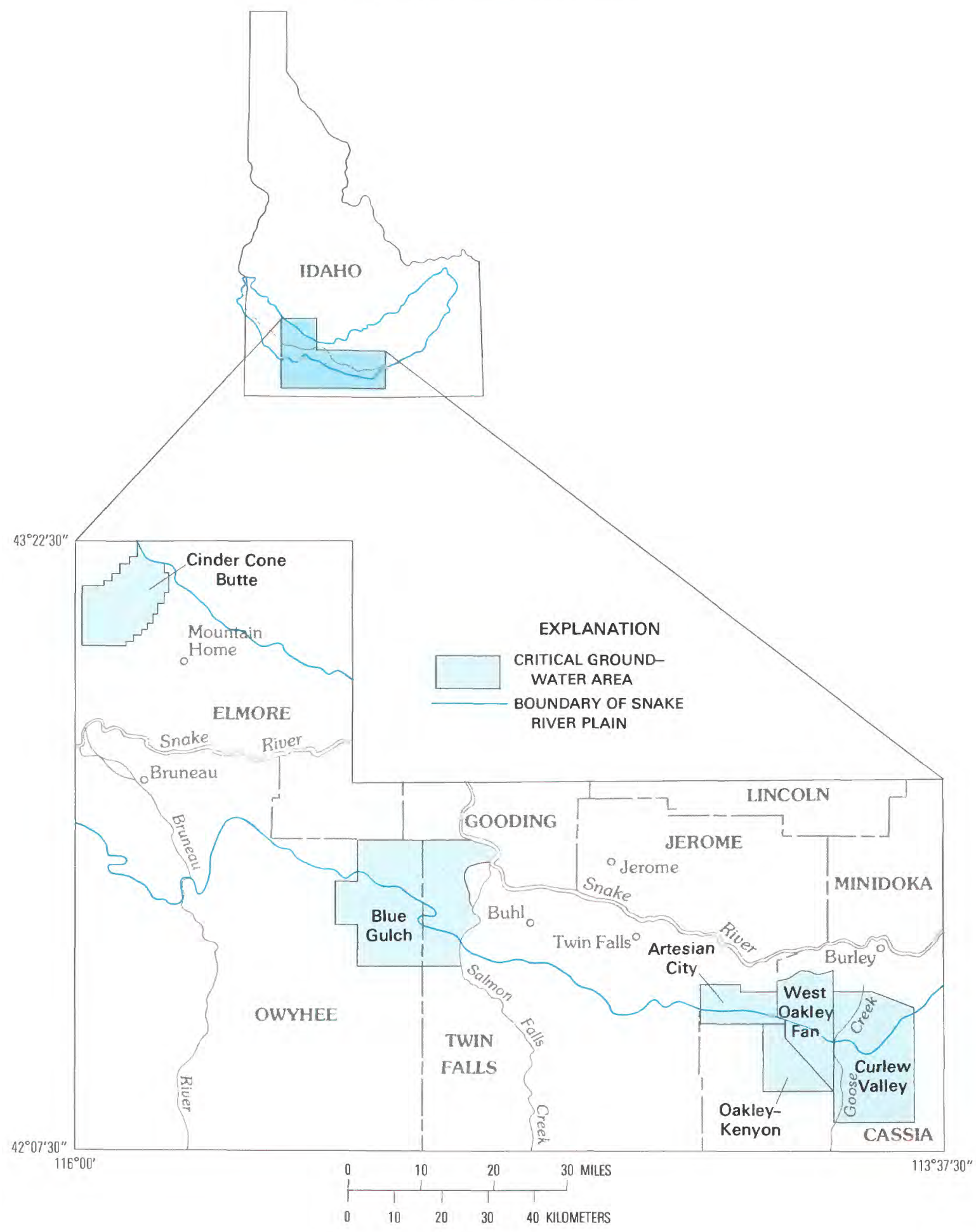

Figure 21.-Locations of Critical Ground-Water Areas.

Ground water has not been developed extensively on the western Snake River Plain. West of Boise, adequate and easily accessible surface water precluded the need for ground-water development. In much of the area east of
Boise, ground-water supplies are inadequate for irrigation. As a result, no large tracts are irrigated exclusively with ground water on the western plain. Most of the 1,280 irrigation wells are in the Boise and Payette River 
valleys (hereafter referred to as the Boise-Payette area). Ground water is used to irrigate smaller areas near Mountain Home and south of Bruneau.

In 1979, ground water was the sole source of water for about 48,000 irrigated acres in the Boise-Payette area and the supplemental source for 13,000 acres (U.S. Bureau of Reclamation, 1980). Many wells are in areas classified as surface-water irrigated on the 1979 map (Bigelow and others, 1984); some drain waterlogged areas. Some water from drain wells is used to irrigate lands that otherwise would be irrigated with surface water.

The regional aquifer system in the Boise-Payette area is complex. The area is underlain by Tertiary and Quaternary sedimentary rocks intercalated with basalt. Sands and gravels and some basalt are the principal aquifers. Quaternary terrace gravels and alluvium are locally important water sources. Well depths range from 20 to more than $1,500 \mathrm{ft}$ and depth to water is generally less than $100 \mathrm{ft}$. In 1980, an estimated 190,000 acre-ft of irrigation water were withdrawn from about 800 wells in the BoisePayette area.

Most irrigation wells northwest and south of Mountain Home were drilled in the 1960's. Excessive ground-water pumping caused water-level declines of as much as $20 \mathrm{ft}$ in 9 years (Young, 1977, p. 2). In 1981, the IDWR designated the area around Cinder Cone Butte a Critical Ground-Water Area (fig. 21) and closed it to further development.

Wells near Mountain Home penetrate local perched aquifers and the regional aquifer. Depths to water range from 50 to $500 \mathrm{ft}$ below land surface. Wells penetrating the regional aquifer are completed mostly in Quaternary basalt of the Bruneau Formation, and water levels are 200 to $500 \mathrm{ft}$ below land surface (Young, 1977, p. 10). Water levels are shallower in wells completed in perched aquifers near Mountain Home. In 1980, an estimated 33,000 acre-ft of water was withdrawn from 88 wells for irrigation around Mountain Home.

Ground-water irrigation south of the Snake River on the western plain is concentrated south of Bruneau. Wells in this area generally range from 700 to $2,100 \mathrm{ft}$ deep and are completed in Tertiary silicic volcanics and the Banbury Basalt. Some irrigation water from the Banbury Basalt is thermal $\left(30-83^{\circ} \mathrm{C}\right)$ and is under artesian pressure (Young and Whitehead, 1975, p. 31). In 1980, an estimated 54,000 acre-ft of irrigation water was withdrawn from 61 wells.

The Boise-Payette, Mountain Home, and Bruneau areas account for about 75 percent of the wells and 80 percent of ground-water pumpage for irrigation on the western Snake River Plain. Water from the remaining wells irrigate smaller tracts that are mostly adjacent to surfacewater-irrigated areas. About 25,000 acres on the western plain are irrigated with both surface and ground water.
Data from Sutter and Corey (1970) were used to estimate evapotranspiration. Consumptive use by groundwater-irrigated crops on the Snake River Plain was about 1.8 million acre-ft of water in 1980 . Of that, about 1.6 million acre-ft was supplied by irrigation water (ground water) and the rest by precipitation. That is, of 2.3 million acre-ft of ground water withdrawn for irrigation on the plain, about 1.6 million acre-ft was consumptive use by crops. The remainder percolated to the aquifers or was returned to surface-water bodies.

A map of estimated annual CIR for ground-waterirrigated areas (fig. 22) is included for comparison with the ground-water pumpage map (fig. 17, both are summarized by 15-minute blocks). Generally, CIR is large, in the same blocks in which estimated pumpage is large and small where pumpage is small. The consistent relation between CIR and estimated pumpage indicates that the distribution of ground-water withdrawals, as presented in this study, is reasonably accurate.

\section{HYDROLOGIC EFFECTS OF IRRIGATION}

Historical data indicate that irrigation has altered the hydrologic system of the Snake River Plain. Construction of dams, reservoirs, and canals, and diversion of large volumes of surface water for irrigation have changed the flow characteristics of the Snake River and many of its tributaries. More recently, the use of ground water for irrigation also has contributed to changes in the hydrologic system.

In the early 1900's, crops were irrigated mainly with surface water; surface-water diversions for irrigation increased as rapidly as irrigated acreage. The immediate effect of large gravity diversions was depletion of streamflow. Table 9 shows irrigated acreage and streamflow depletions in the Snake River basin for 10-year intervals between 1870 and 1940 (Simons, 1953, p. 70, 93). Most surface-water-irrigated areas were developed during this period.

Unregulated streamflows during the irrigation season were rapidly appropriated and, in the early 1900 's, reservoirs were constructed to adjust the location and seasonal availability of water. Reservoirs alter the annual distribution of streamflow by retaining spring runoff for use during the irrigation season. Kjelstrom (1984) showed that high flows of May and June declined as surface-water regulation increased. More than 9 million acre-ft of spring runoff is retained in storage reservoirs and is available for release during low-flow months.

Surface-water gravity diversions typically exceed the irrigation requirement by a factor of 2 or more. Some water seeps from canals and reservoirs or percolates through the soil in irrigated areas and recharges the aquifers. Thus, historically, ground-water recharge in- 

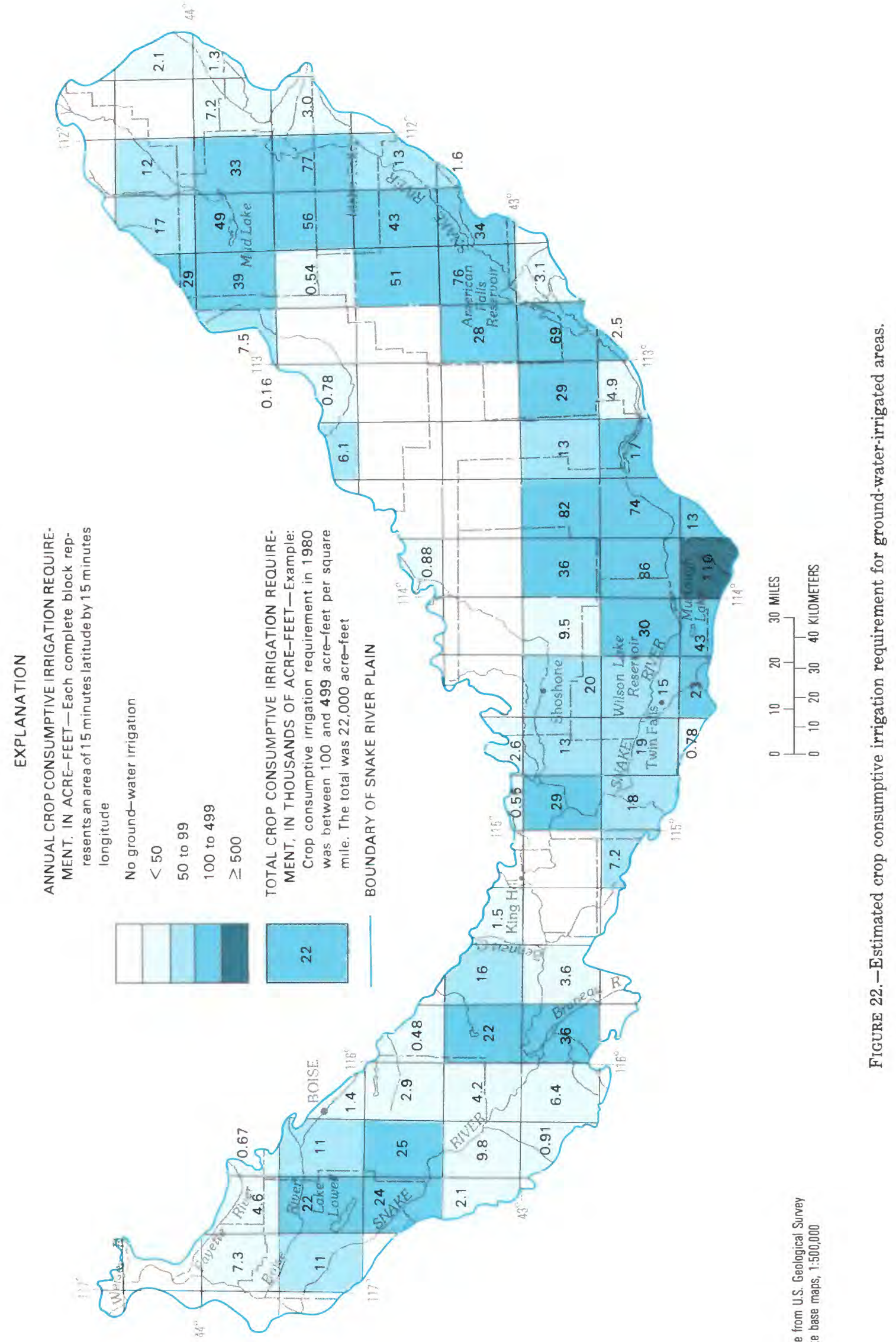
TABLE 9.-Upstream irrigated area and streamflow depletion for the Snake River at King Hill and Weiser, 1870-1940

[Modified from Simons $(1953$, p. 70,93$)]$

\begin{tabular}{|c|c|c|c|c|}
\hline \multirow[b]{2}{*}{ Year } & \multicolumn{2}{|c|}{ Snake River at King $\mathrm{Hill}$} & \multicolumn{2}{|c|}{ Snake River at Weiser ${ }^{1}$} \\
\hline & $\begin{array}{l}\text { Irrigated area } \\
\text { (acres) }\end{array}$ & $\begin{array}{l}\text { Streamflow depletion } \\
\text { (acre-feet per year) }\end{array}$ & $\begin{array}{l}\text { Irrigated area } \\
\text { (acres) }\end{array}$ & $\begin{array}{l}\text { Streamflow depletion } \\
\text { (acre-feet per year) }\end{array}$ \\
\hline $\begin{array}{l}1870 \ldots \ldots \\
1880 \ldots \ldots \\
1890 \ldots \ldots \\
1900 \ldots \ldots \\
1910 \ldots \ldots \\
1920 \ldots \ldots \\
1930 \ldots \ldots \\
1940 \ldots \ldots\end{array}$ & 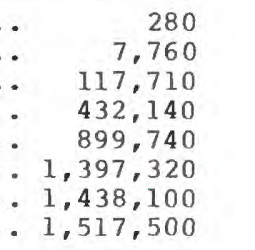 & $\begin{array}{r}450 \\
13,000 \\
176,000 \\
660,000 \\
1,403,000 \\
2,258,000 \\
2,322,000 \\
2,459,000\end{array}$ & $\begin{array}{r}10,287 \\
43,511 \\
229,383 \\
635,169 \\
1,312,724 \\
2,044,168 \\
2,151,494 \\
2,342,955\end{array}$ & $\begin{array}{r}20,650 \\
80,520 \\
373,480 \\
1,028,500 \\
2,184,060 \\
3,497,780 \\
3,568,530 \\
4,013,390\end{array}$ \\
\hline
\end{tabular}

${ }^{1}$ Includes irriqated area and depletions above King Hill.

creased with surface-water diversions and reservoir construction. The result was long-term increases in aquifer storage and ground-water discharge.

The quantity of ground water in aquifer storage increased in most irrigated areas on the plain soon after surface-water irrigation began. Water levels in wells on the eastern Snake River Plain rose from a few feet to as much as $200 \mathrm{ft}$ in Twin Falls County (fig. 23). L.C. Kjelstrom (U.S. Geological Survey, written commun., 1984) reported an average water-level rise of about $50 \mathrm{ft}$ on the eastern plain between 1890 and 1952 and a corresponding 24 million acre-ft increase in aquifer storage. Owing to insufficient water-level data prior to 1930 , similar estimates for the western plain are not possible. However, Nace and others (1957, p. 9-10) reported that water levels in wells in Boise River valley began to rise markedly in 1912 and continued until the mid-1930's, shortly after most surface-water-irrigable lands were developed.

In some places, rising water levels caused waterlogging and consequent drainage problems. In the early 1900 's, water levels began to rise owing to recharge from excess irrigation water and seepage from surface impoundments. Waterlogging was particularly a problem in the BoisePayette area, where drainage districts constructed a complex system of drains and wasteways. Waterlogging also was a problem in the Minidoka Project area and in seep areas northwest of American Falls Reservoir (Stearns and others, 1938, p. 119, 128).

In other places, a shallow water table makes water more accessible and less expensive to pump. The long history of ground-water pumpage near Mud Lake is due in part to the shallow water table. Water levels on Egin Bench rise to within $5 \mathrm{ft}$ of land surface during the irrigation season, allowing many farmers to use the higher water table for irrigation at the root level of crops.
Increased recharge owing to irrigation also caused increased ground-water discharge. Before ground-water pumping became an important irrigation water source, most ground-water discharge from the eastern plain was spring flow in two areas: immediately upstream from American Falls Reservoir, and along the north wall of the Snake River canyon between Milner and King Hill. Kjelstrom (1984) showed that ground-water discharge (mostly spring flow) to the Snake River from Milner to King Hill increased from $4,200 \mathrm{ft}^{3} / \mathrm{s}$ in 1905 to $6,800 \mathrm{ft}^{3} / \mathrm{s}$ in 1951 (fig. 24). Most of the increase was due to increased

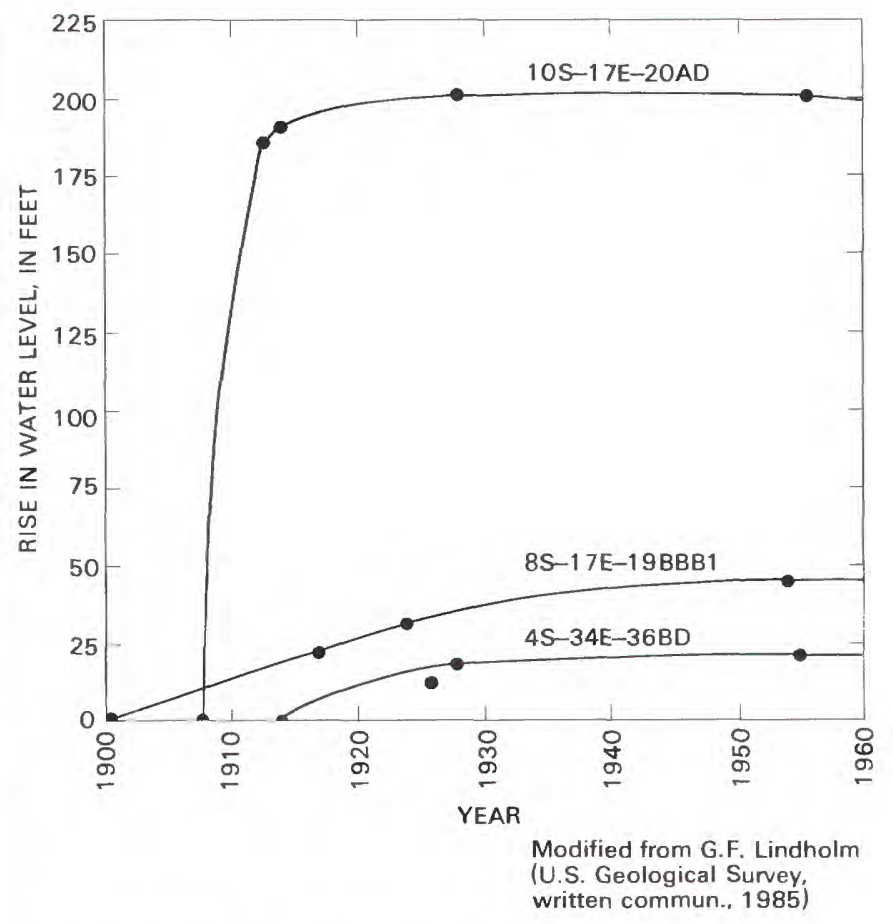

FIGURE 23.-Water-level rises in three wells, 1900-1960. 
recharge from surface-water irrigation immediately north and east of the springs. Data on spring flow in the American Falls Reservoir area since 1912 do not show a similar trend. These springs drain a narrow strip of land along the Snake River that was mostly put under surfacewater irrigation prior to 1912 . The hydrologic system in this area probably reached equilibrium during the 1900 's before discharge measurements were made.

After World War II, several factors combined to reduce net ground-water recharge from irrigation. The largest factor was annual increases in ground-water pumpage after about 1950 . At the same time, irrigators converted to more efficient distribution systems that reduced the amount of water applied to fields. Also, lining of irrigation canals reduced conveyance losses. As a result, net ground-water recharge decreased and water levels in wells and spring flow declined.

Water levels have declined in wells across most of the eastern plain, on the Mountain Home plateau, and in scattered localities on the rest of the western plain. Waterlevel declines range from a few to several tens of feet and, locally, in heavily pumped areas near the margins of the plain, water-level declines are as much as several hundred feet. Figure 25 is the hydrograph of a well in Minidoka County that shows long-term water-level declines. The downward trend was temporarily reversed from the early 1960 's to the early 1970 's by fluctuations owing to climatic variations, but the overall 15 -ft decline from 1950 to 1982 is clear. In Critical Ground-Water Areas, the IDWR has determined that withdrawals have exceeded recharge and water levels have declined to unacceptable levels.

Ground-water discharge to the Snake River from Milner to King Hill decreased by about $600 \mathrm{ft}^{3} / \mathrm{s}$ between 1951 and 1980 (fig. 24). Decreases are due largely to increased consumptive use in new ground-water-irrigated areas immediately north and east of the springs (L.C. Kjelstrom, U.S. Geological Survey, written commun., 1984).

On the eastern plain, declining water levels and spring flow suggest that ground-water pumpage since 1950 has reduced both aquifer storage and ground-water discharge. On the western plain, the effects of new ground-water pumpage are more difficult to assess. In the Mountain

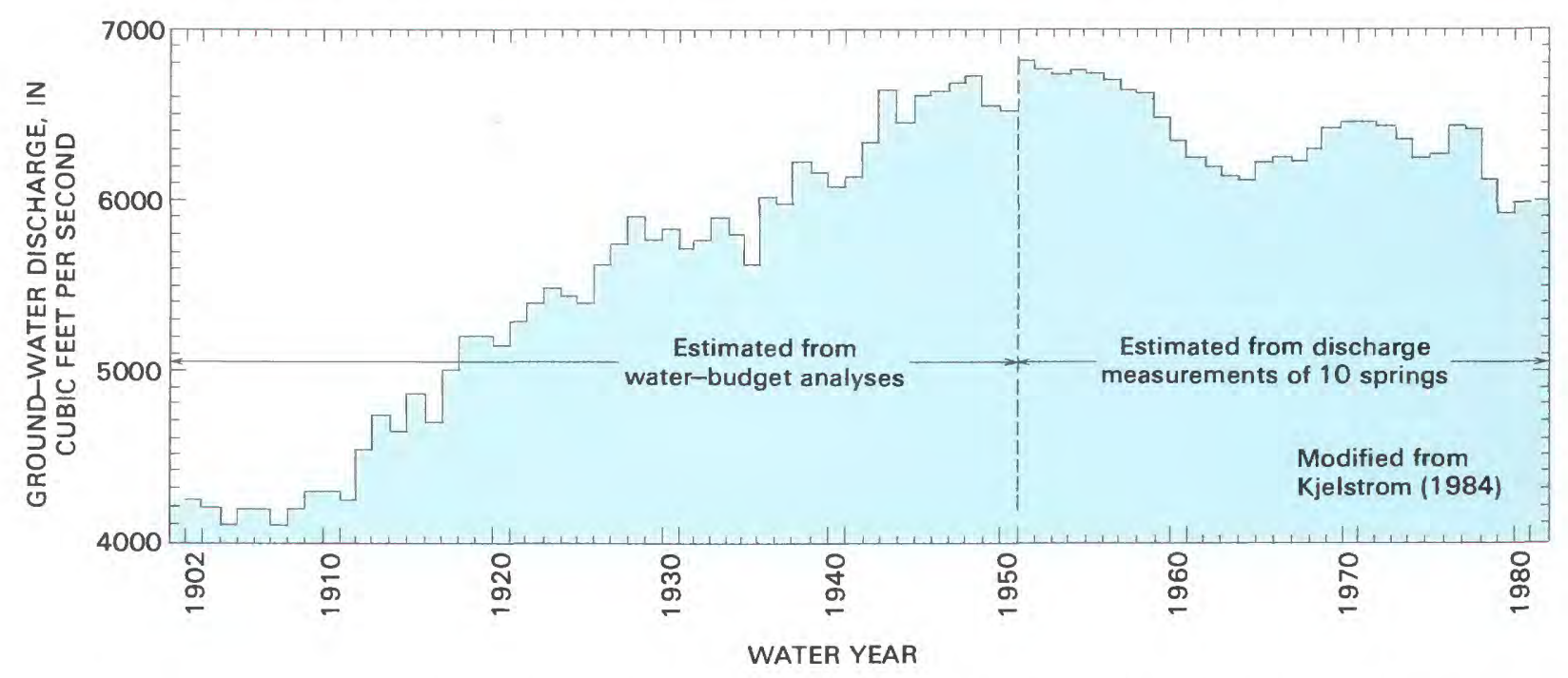

FIGURE 24.-Average annual ground-water discharge from north side of Snake River between Milner and King Hill.

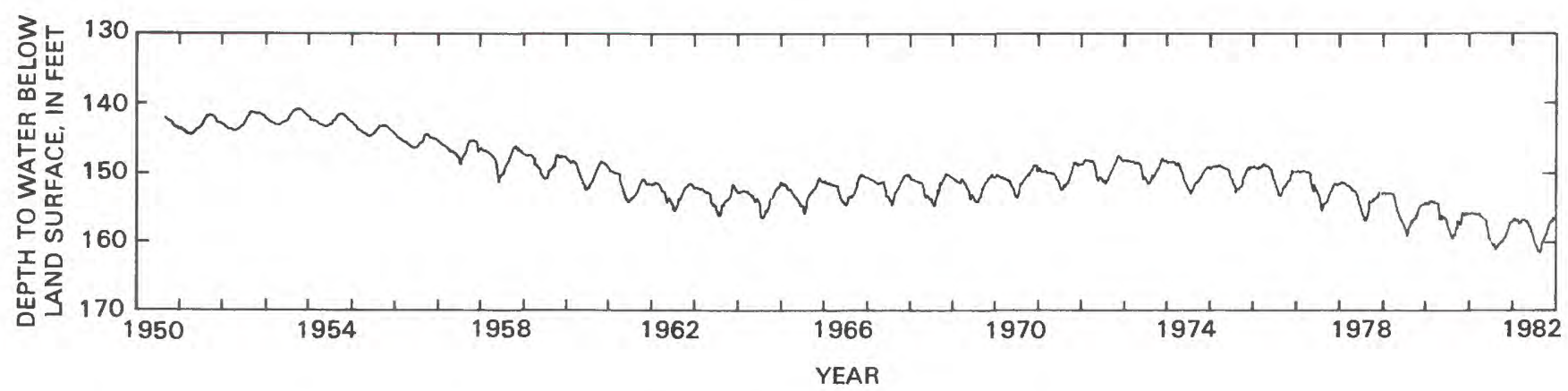

FIgure 25.-Declining water levels in well 8S-24E-31DAC1, in Minidoka County. 
Home area, pumping has caused marked and continuous water-level declines. In the Boise-Payette area, water levels are declining in some wells and rising in others, probably because of varying stresses on different parts of the aquifers.

In some tributary basins, agricultural development and consequent crop evapotranspiration of surface and ground water have reduced available water flowing to the plain. Most water available to the Snake River Plain originates as surface-water inflow and ground-water underflow from tributary basins. Kjelstrom (1984) estimated available water flowing from tributary basins to the eastern and western plain on the basis of (1) present irrigation development and (2) no development or reservoir storage in tributary basins. According to his figures, on the average, agricultural development in tributary basins has reduced annual available water flowing to the eastern plain by about 7 percent (from 10.972 million acre-ft to 10.215 million acre-ft) and to the western plain by about 23 percent (from 18.89 to 14.604 million acre-ft) for water years $1934-1980$.

W.W. Wood and W.H. Low (U.S. Geological Survey, written commun., 1984) described aqueous geochemistry of ground water underlying the Snake River Plain, including effects of irrigation on ground-water chemistry. Generally, recharge from excess surface water applied to crops results in higher concentrations of sulfate, chloride, and sodium in ground water. However, increases in solute concentrations owing to recharge from irrigation-return flow are generally smaller than expected because the chemical compositions of most surface and ground waters on the plain are similar. Higher solute concentrations in irrigated areas result in part from evapotranspiration that concentrates solutes in the recharge water.

Norvitch and others $(1969$, p. 26) also noted higher concentrations of total dissolved solids, as well as sulfate, chloride, and sodium in ground water underlying irrigated areas. Dissolved solids in ground water averaged less than $250 \mathrm{mg} / \mathrm{L}$ (milligrams per liter) under nonirrigated areas and more than $250 \mathrm{mg} / \mathrm{L}$ under irrigated areas. Seitz and others $(1977$, p. 32) observed some local chemical effects of irrigation drain wells, particularly increased concentrations of dissolved solids, nutrients, and bacteria, but did not observe any regional effects.

\section{OTHER OFFSTREAM WATER USES}

Although irrigation is by far the largest use of water on the Snake River Plain, other offstream uses are important to the State's economy. Idaho industries, particularly food processing and aquaculture, depend on the ample supply of good quality water. The plain's inhabitants also use water for domestic, commercial, and public purposes. Though small relative to irrigation, these water uses are essential to the inhabitants of the plain and to the State's largely agricultural economy.

\section{INDUSTRIAL}

Industrial withdrawals in Idaho were estimated by IDWR (1983) based on a 1978 survey of industrial water users. They inventoried Idaho industries to estimate average annual withdrawal per employee for each industry in the State. Annual withdrawal for each industry was estimated by multiplying annual withdrawal per employee times the number of employees (Center for Business Development and Research, 1982). Oregon industrial water use was estimated using the withdrawal peremployee-use rates determined in Idaho and industrial employment data estimated for Oregon (Oregon Economic Development Department, 1983, p. 73). Locations and relative amounts of water withdrawn for industrial use on the Snake River Plain are shown in figure 26, and totals for each county are presented in table 10.

Water is used in industry for manufacturing processes, cooling, and employee sanitation. Industries with high water use usually have water-intensive manufacturing processes. Industries on the Snake River Plain with high annual withdrawals include food processing and lumber, fertilizer, and concrete manufacturing. Food-processing industries withdraw relatively large volumes of water for meat packing; fruit, vegetable, and fish preparation and preservation; and beet sugar refining. Food-processing industries are concentrated around Idaho Falls, Burley, Twin Falls, Boise, and Payette. Large quantities of water are used by the phosphate-processing industry near Pocatello and by the lumber industry in Emmett.

Withdrawals for food processing have a distinct seasonal pattern (PNRBC, 1971b, p. 84). Water use for sugar refining and potato processing is highest from September through March. Water use for canning and freezing of fruits and vegetables peaks from July through October. Water use for milk- and meat-processing industries is relatively constant throughout the year.

Industrial water withdrawals on the Snake River Plain were about 71,300 acre-ft in 1980. About 52,500 acre-ft was ground water, 7,400 acre-ft was surface water, and 11,400 acre-ft was from public water supplies. Ground water is the source of at least 95 percent of the public water supplies in cities with industrial water users (Association of Idaho Cities, 1980). According to Solley and others $(1983$, p. 22), consumptive use of industrial withdrawals in Idaho was about 8 percent. Thus, consumptive use of industrial withdrawals on the Snake River Plain was estimated to be 5,700 acre-ft. In 1971, water used by industries in Idaho was recycled an average of two times before disposal (IWRB, 1972, p. 78). 


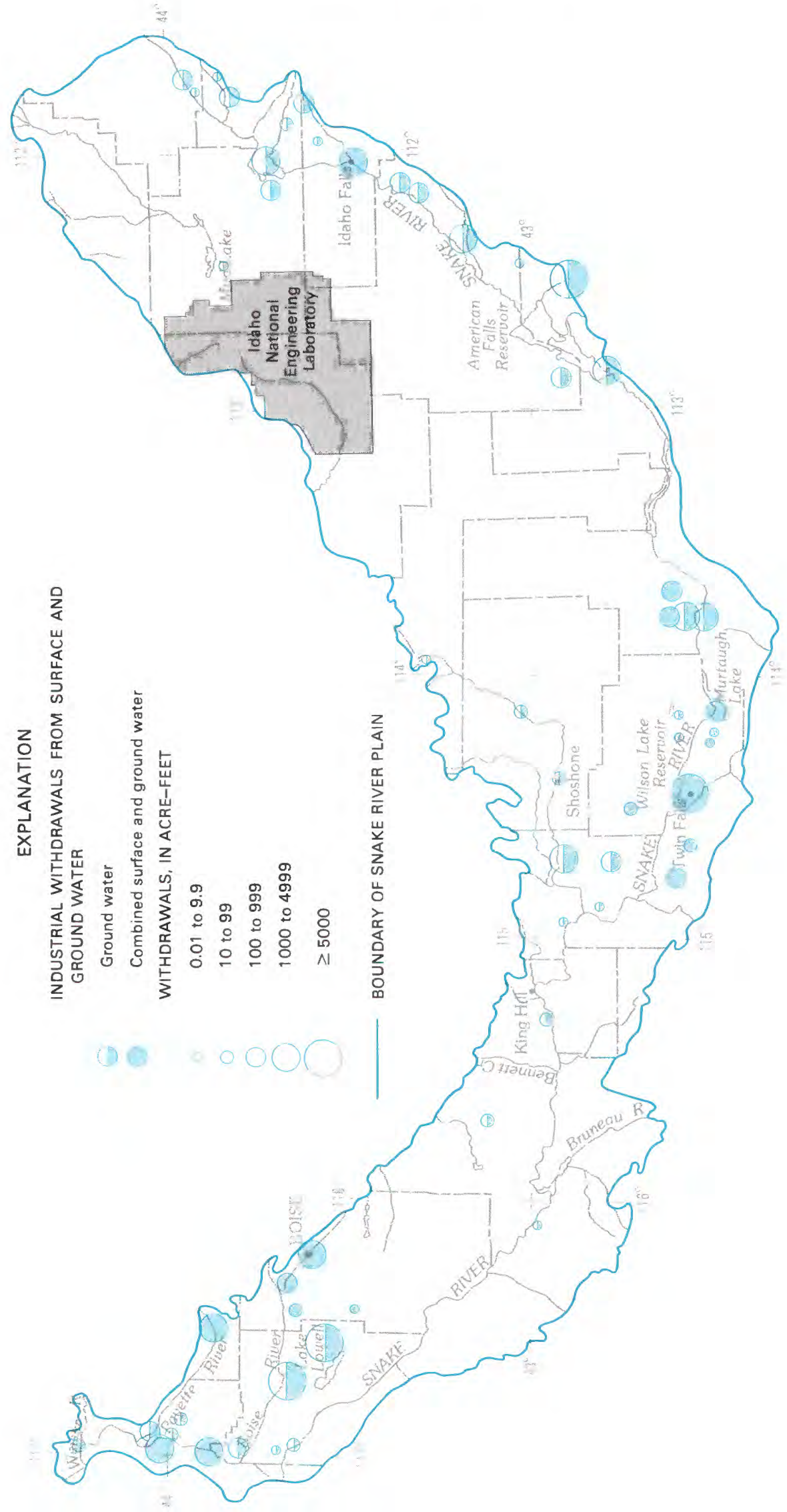

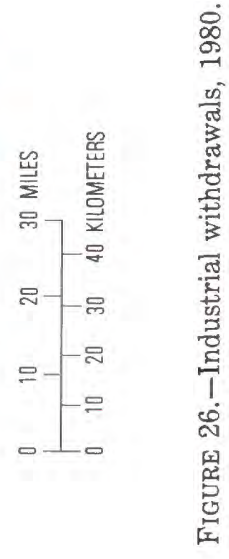

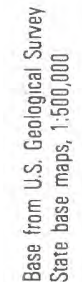


TABLE 10.-Industrial water use by county, 1980

$[<$, less than]

\begin{tabular}{|c|c|c|c|c|}
\hline \multirow[b]{2}{*}{ County } & \multirow[b]{2}{*}{$\begin{array}{c}\text { Total } \\
\text { withdrawal } \\
\text { (acre-feet) }\end{array}$} & \multicolumn{2}{|c|}{ Source of supplies } & \multirow[b]{2}{*}{$\begin{array}{c}\text { Publ ic-supply } \\
\text { systems } \\
\text { (acre-feet) }\end{array}$} \\
\hline & & $\begin{array}{l}\text { Ground water } \\
\text { (acre-feet) }\end{array}$ & $\begin{array}{c}\text { Surface water } \\
(\text { acre-feet })\end{array}$ & \\
\hline Ada........ & 2,800 & 700 & 1,500 & 600 \\
\hline Bannock....... & $.10,600$ & 10,500 & 0 & 100 \\
\hline Bingham....... & . 5,050 & 5,000 & 0 & 50 \\
\hline Blaine........ & $<10$ & $<5$ & 0 & $<5$ \\
\hline Bonneville... & 2,530 & 20 & 10 & 2,500 \\
\hline Butte........ & 0 & 0 & 0 & 0 \\
\hline Canyon......... & . 14,970 & 14,900 & 0 & 70 \\
\hline Cassia........ & . 4,440 & 4,400 & 0 & 40 \\
\hline Clark......... & 0 & 0 & 0 & 0 \\
\hline Elmore........ & 40 & 0 & 0 & 40 \\
\hline Fremont...... & 800 & 800 & 0 & 0 \\
\hline Gem......... & 4,000 & 100 & 3,900 & 0 \\
\hline Gooding....... & 1,790 & 1,700 & 0 & 90 \\
\hline Jefferson..... & 2,000 & 2,000 & 0 & $<5$ \\
\hline Jerome........ & 100 & 40 & 40 & 20 \\
\hline Lincoln....... & 80 & 0 & 0 & 80 \\
\hline Madison....... & 400 & 200 & 0 & 200 \\
\hline Malheur, Oreg. & 4,000 & 1,400 & 1,000 & 1,600 \\
\hline Minidoka..... & 3,400 & 2,800 & $<5$ & 600 \\
\hline Owyhee........ & 30 & 0 & 0 & 30 \\
\hline Payette...... & 550 & 50 & 0 & 500 \\
\hline Power ........ & . 2,800 & 2,800 & 0 & $<5$ \\
\hline Twin Falls.... & 10,900 & 5,100 & 900 & 4,900 \\
\hline Washington.... & . 30 & $<5$ & 20 & 10 \\
\hline Total.... & . 71,310 & 52,510 & 7,370 & 11,430 \\
\hline
\end{tabular}

${ }^{1}$ See table 12 for source of public-supply water.

\section{AQUACULTURE}

Aquaculture, the practice of raising fish and shellfish in managed habitats, is one of Idaho's largest industrial water uses. At least 90 percent of Idaho's commercial fish farms are located in the Snake River canyon between Twin Falls and Hagerman, a major discharge area for the Snake River Plain aquifer. The water quality of hundreds of springs emerging from the northeastern canyon wall is exceptionally well suited to cold-water fish farming. Idaho produces 90 percent of processed rainbow trout in the United States (Klontz and King, 1975, p. 53). In addition to rainbow trout, Idaho commercially produces channel catfish, coho salmon, and cutthroat trout. Other types of aquaculture include egg production, fish processing, fee-fishing, feed manufacturing, and live-hauling of fish for stocking in other States.

Water withdrawals for commercial aquaculture were estimated from data on the sizes of food-fish farms in Idaho (Klontz and King, 1975). Volume of fish-rearing space was multiplied by the number of water replacements per year for each fish farm. Klontz and King (1975) reported minimum and maximum replacement times for each farm, so the midpoint was used to calculate the number of replacements per year.

Withdrawals for Federal- and State-operated fish farms were estimated from average flow rates provided by managing agencies (Idaho Department of Fish and Game, 1980; D.S. Bruhn, U.S. Fish and Wildlife Service, oral commun., 1984).

In 1980, commercial fish farms on the Snake River Plain withdrew about 1.7 million acre-ft of water. Four gamefish hatcheries operated by the Idaho Department of Fish and Game and one operated by the U.S. Fish and Wildlife Service withdrew about 200,000 acre-ft. Estimated withdrawals by county for aquaculture are shown in table 11, and locations of fish farms are shown in figure 27. Except for about 100,000 acre-ft withdrawn from wells and streams, water for aquaculture is from springs. Consumptive use in fish farm operations is negligible; some losses are due to evaporation from exposed water surfaces in ponds and raceways. Assuming each of the 33 fish farms on the plain has 10 acres of ponds and raceways, and 
TABLE 11.-Aquaculture water use by county, 1980

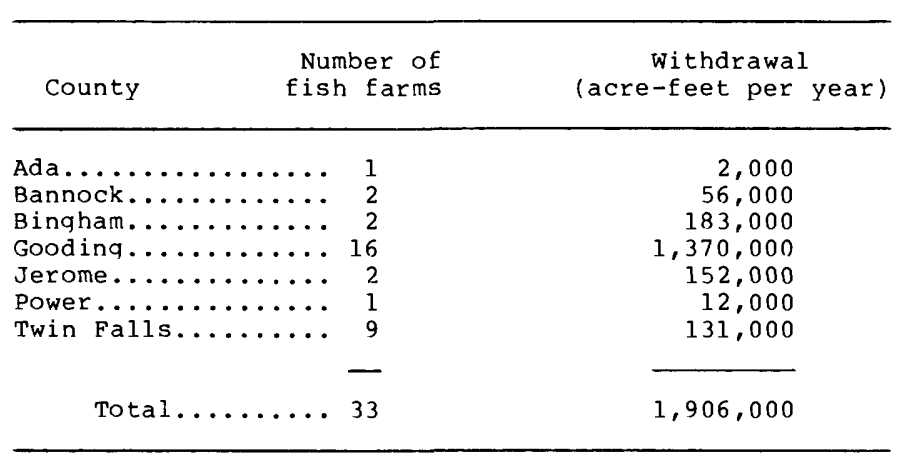

annual evaporation from open water is $36 \mathrm{in./yr}$, total consumptive use by fish farms would equal 990 acre-ft/yr. Few, if any, fish farms have 10 acres of open water and most have much less, so consumptive use by aquaculture on the Snake River Plain probably amounts to less than 1,000 acre-ft/yr.

\section{NONINDUSTRIAL PUBLIC SUPPLY}

Nonindustrial public supply refers to water withdrawn by public and private water suppliers and delivered for domestic, public, and commercial uses. Domestic uses include drinking, food preparation, washing, and lawn and garden watering. Public uses include schools, fire departments, and municipal parks. Most commercial establishments also use public supplies.

Nonindustrial public-supply withdrawals in Idaho were estimated using the equation:

$$
Q=[(P)(231 \mathrm{gal} / \mathrm{d})(0.00112015)]-I
$$

where

$Q$ is volume withdrawn for nonindustrial public supply, in acre-feet;

$P$ is population served by public supplies; and

$I$ is public-supply withdrawals for industrial use, in acre-feet.

Data on population served by public supplies and publicsupply withdrawals for industrial use were provided by IDWR. The value for per-capita public-supply withdrawals $(231 \mathrm{gal} / \mathrm{d})$ is the average reported value for Idaho in 1980 (Solley and others, 1983, p. 10). The constant $(0.00112015)$ converts gallons per day to acre-feet per year. Volumes withdrawn for public supply in Malheur County, Oregon, were reported by D.D. Nebert (U.S. Geological Survey, oral commun., 1983).

In 1980 , about 102,000 acre-ft of water was withdrawn on the Snake River Plain for nonindustrial public-supply uses. Table 12 shows estimated withdrawals, population served, and source of water by county, and figure 28 shows the locations of public-supply withdrawals. More than 95 percent of public supply is ground water (Association of Idaho Cities, 1980). Solley and others (1983, p. 10) reported that consumptive use of nonindustrial public supply in Idaho was about 22 percent. On the basis of this rate, consumptive use of nonindustrial public supply in 1980 on the Snake River Plain was estimated to be about 22,000 acre-ft.

\section{RURAL}

Rural water use includes water for domestic and livestock needs supplied by private systems. Domestic withdrawals were estimated using $98 \mathrm{gal} / \mathrm{d}$ per person, which is the average per-capita rural domestic use for the 17 Western States (Solley and others, 1983, p. 33). To determine the population supplied by private systems in each county, the population supplied by public systems was subtracted from the total 1980 population. However, parts of counties lie outside the study area. In those counties, rural populations were assumed to be distributed uniformly over the county and thus were multiplied by the percentage of the county in the study area. All rural domestic water is assumed to be ground water.

Amount and source of withdrawals for livestock were derived from estimates prepared for a national water-use summary. Withdrawals for livestock were assumed to be distributed uniformly within each county and were adjusted as above for those counties partially outside the study area.

Withdrawals for livestock in Malheur County, Oregon, were estimated from reported livestock populations (U.S. Bureau of the Census, 1981; Oregon Crop and Livestock Reporting Service, 1982). Total populations of horses, cattle, sheep, pigs, chickens, and goats were multiplied by their daily per-capita use as reported by Murray (1968, p. 4) and by the percentage of Malheur County included in the study area. Withdrawals were assumed to be equally from surface and ground water.

Amounts of rural domestic and livestock withdrawals are presented by county in table 13 and locations are shown in figure 28. In 1980, an estimated 23,000 acre-ft was withdrawn from surface and ground water for rural uses. About 13,000 acre-ft was used for domestic purposes and 10,000 acre-ft for livestock. In previous water-use estimates, the U.S. Geological Survey (Solley and others, 1983, p. 14) reported that consumptive use was about 24 percent of domestic withdrawals and 86 percent of livestock withdrawals. On the basis of these rates, consumptive use of rural domestic and livestock withdrawals was estimated to be about 11,800 acre-ft. 
WATER USE ON THE SNAKE RIVER PLAIN

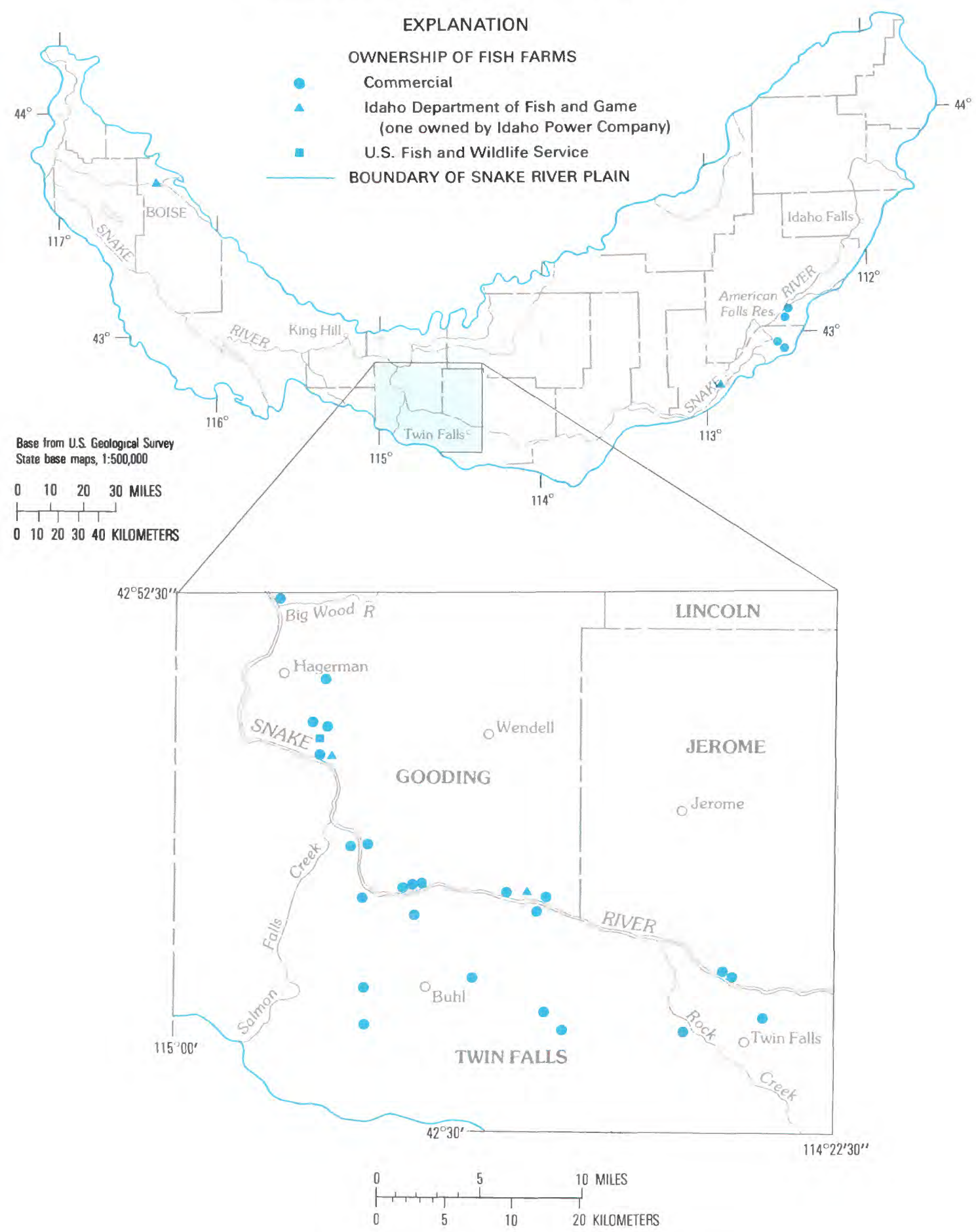

FIGURE 27.-Locations of fish farms.

\section{IDAHO NATIONAL ENGINEERING LABORATORY}

The INEL (Idaho National Engineering Laboratory) site (fig. 26), which consists of about $900 \mathrm{mi}^{2}$ of the eastern plain, was established in 1949 by the Atomic Energy Commission (later reorganized as the Department of Energy) to build, operate, and test nuclear reactors. Ground water is withdrawn onsite for cooling and processing uses. Lewis and Jensen (1984) reported that ground-water withdrawals at INEL averaged about 7,400 acre-ft/yr from 1979 to 1981 . About 90 percent was withdrawn in Butte County and 10 percent in Bingham 
TABLE 12.-Nonindustrial public-supply water use and population served by connty, 1980

$[<$, less than]

\begin{tabular}{|c|c|c|c|}
\hline County & $\begin{array}{l}\text { Population } \\
\text { served by } \\
\text { public } \\
\text { supplies }\end{array}$ & $\begin{array}{l}\text { Withdrawal } \\
\text { for public } \\
\text { supply } \\
\text { (acre-feet } \\
\text { per year) }\end{array}$ & $\begin{array}{l}\text { Source of water } \\
\text { (G, ground water; } \\
\text { S, surface water) }\end{array}$ \\
\hline Ada............ & 141,940 & 36,100 & G \\
\hline Bannock......... & 16,430 & 4.200 & G \\
\hline Bingham......... & - 18,790 & 4,700 & G \\
\hline 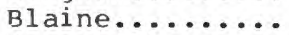 & 160 & $<100$ & G \\
\hline Bonneville...... & 50,120 & 10,500 & G \\
\hline Butte.......... & 1,320 & 300 & G \\
\hline Canyon.......... & 58,810 & 15,200 & G \\
\hline Cassia.......... & 10,860 & 2,800 & G \\
\hline 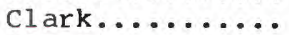 & 540 & 100 & G \\
\hline Elmore......... & 17,250 & 4,400 & G \\
\hline Fremont........ & 4,870 & 1.300 & G \\
\hline Gem.......... & 5,290 & 1,400 & $\mathrm{G}$ \\
\hline Gooding......... & 5,880 & 1,400 & G \\
\hline Jefferson........ & 5,280 & 1,400 & G \\
\hline Jerome......... & 8,630 & 2,200 & G \\
\hline Lincoln........ & 1,620 & 300 & G \\
\hline Madison......... & 12,290 & 3,000 & G \\
\hline Malheur, Oreq... & 12,100 & 1,600 & $\mathrm{G}, \mathrm{S}$ \\
\hline Minidoka......... & 12,070 & 2,500 & G \\
\hline Owyhee.......... & 3,270 & 800 & $G, S$ \\
\hline Payette........ & 10,310 & 2,200 & G \\
\hline power .......... & 3,880 & 1,000 & G \\
\hline Twin Falls..... & 33,340 & 3,800 & G \\
\hline Washington..... & 4,860 & 1,200 & $G, S$ \\
\hline Total..... & 439,910 & 102,400 & \\
\hline
\end{tabular}

and Jefferson Counties. Consumptive use was 53 percent, or 3,900 acre-ft. The rest was returned to the aquifer via injection and drain wells and leaching ponds.

\section{INSTREAM WATER USES}

Instream water uses do not involve either withdrawals or significant consumptive use of water. However, when perfected as senior water rights, they limit the availability of water for other uses by requiring continuous minimum flows at specific locations. Instream water uses include hydroelectric power generation, minimum flows for fish habitat preservation, and recreation.

\section{HYDROELECTRIC POWER GENERATION}

Since the early 1900 's, availability of inexpensive hydroelectric power has been important to Idaho's economic development. With an abundance of free-flowing water, Idaho has relied almost exclusively on hydroelectric power. About half of the State's hydroelectric power facilities are within the study area on the Snake River and its tributaries (fig. 29).
An estimated 52 million acre-ft of water was used in 1980 to generate 2.6 million MWh of electricity on the Snake River Plain. This is about 30 percent of the total hydropower generation in Idaho. About 39.4 million acre$\mathrm{ft}$ of water was used on the eastern plain and 12.3 million on the western plain.

Water use for hydropower generation was estimated by IDWR from power generation data provided by the Federal Energy Regulatory Commission. Data on water use and power produced in 1980 are shown by county in table 14 . Virtually none of this water was consumptively used; after passing through a power generation plant, the water was available for downstream use. The small amount of water evaporated from reservoirs associated with hydropower generation is accounted for as evaporation from open water.

Continued instream flows are necessary to generate electricity at current levels. During early development of Idaho's water resources, abundant supplies precluded competition between power generation and other water uses. As development proceeded, competition for water use increased. When flows are low, consumptive water use upstream from a power generating facility reduces the amount of water available for power generation. 


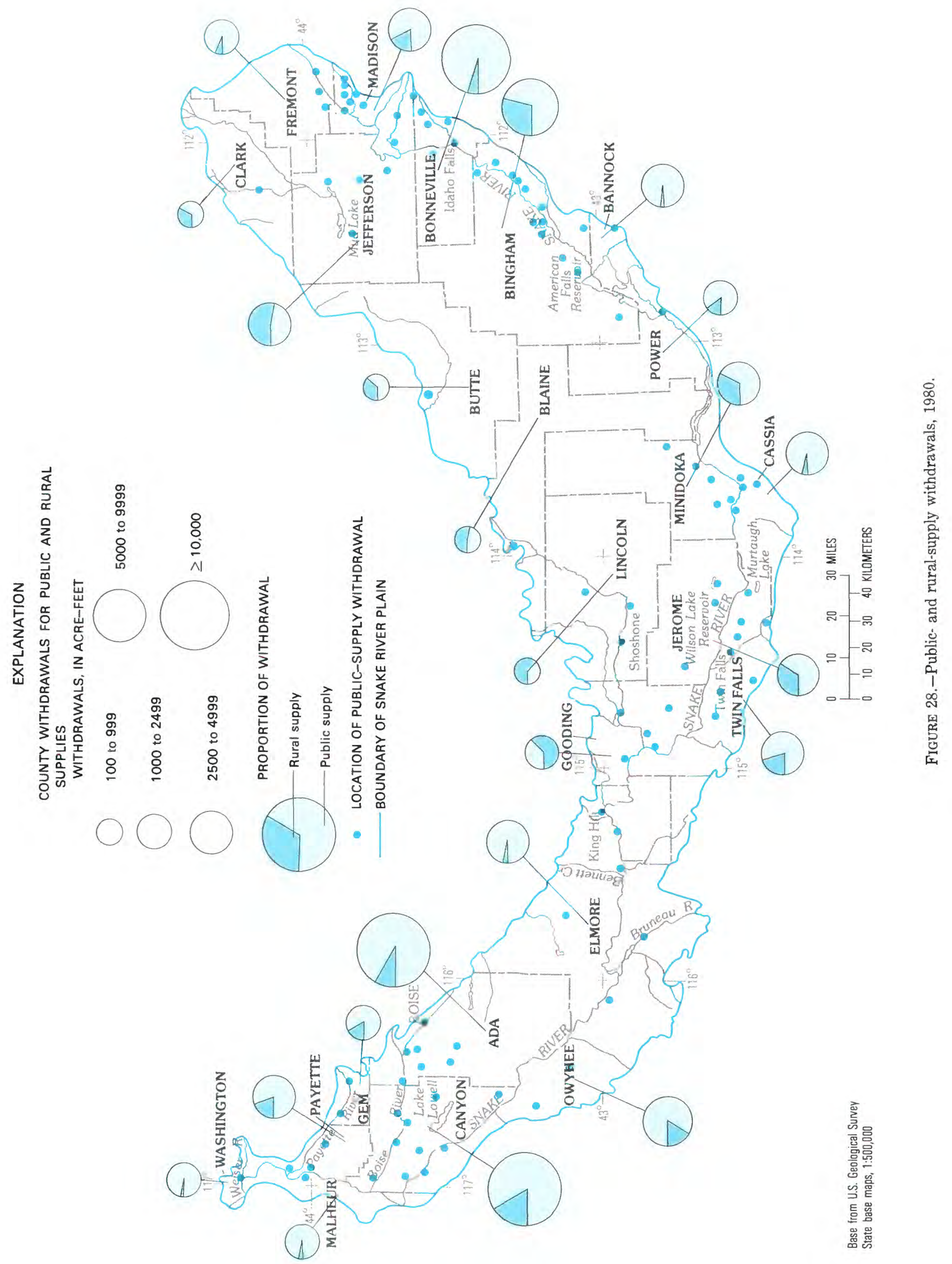


TABLE 13.-Rural domestic and livestock water use by county, 1980

\begin{tabular}{|c|c|c|c|c|}
\hline \multirow[b]{2}{*}{ County } & \multirow{2}{*}{$\begin{array}{c}\text { Rural } \\
\text { population } \\
\text { in study } \\
\text { area }\end{array}$} & \multirow{2}{*}{$\begin{array}{c}\text { Rural } \\
\text { domestic } \\
\text { withdrawal } \\
(\text { acre-feet) }\end{array}$} & \multicolumn{2}{|c|}{$\begin{array}{c}\text { Livestock withdrawal } \\
\text { (acre-feet) }\end{array}$} \\
\hline & & & surface water & Ground water \\
\hline Ada........... & 26,800 & 2,900 & 300 & 700 \\
\hline Bannock........ & 500 & 60 & 20 & 10 \\
\hline Bingham....... & 11,700 & 1,300 & 600 & 300 \\
\hline Blaine........ & 800 & 90 & 100 & 40 \\
\hline Bonneville... & 3,500 & 400 & 100 & 50 \\
\hline Butte........ & 900 & 100 & 80 & 80 \\
\hline Canyon........ & 25,000 & 2,700 & 600 & 1,400 \\
\hline Cassia....... & 1,000 & 100 & 70 & 100 \\
\hline Clark......... & 100 & 10 & 50 & 30 \\
\hline Elmore....... & 1,300 & 100 & 100 & 30 \\
\hline Fremont....... & 400 & 40 & 70 & 50 \\
\hline Gem......... & 1,400 & 200 & 20 & 90 \\
\hline Gooding........ & 4,000 & 400 & 400 & 400 \\
\hline Jefferson..... & 8,700 & 1,000 & 500 & 200 \\
\hline Jerome....... & 6,200 & 700 & 400 & 300 \\
\hline Lincoln....... & 1,700 & 200 & 200 & 300 \\
\hline Madison........ & 4,200 & 500 & 100 & 60 \\
\hline Malheur, Oreq. & 300 & 30 & 30 & 30 \\
\hline Minidoka...... & 7,600 & 800 & 600 & 400 \\
\hline Owyhee........ & 900 & 100 & 100 & 100 \\
\hline Payette...... & 2,800 & 300 & 200 & 70 \\
\hline Power.......... & 900 & 100 & 80 & 80 \\
\hline Twin Falls.... & 6,200 & 700 & 400 & 200 \\
\hline Washington.... & 200 & 20 & 30 & 10 \\
\hline Total.... & 117,100 & 12,850 & 5,150 & 5,030 \\
\hline
\end{tabular}

Small hydropower generation is a new element in Idaho's total power production complex. Most economical large dam sites in Idaho are already developed. Smallscale power generation is encouraged by a 1978 Federal law requiring major utilities to buy power from small generators. Since 1980 , more than 150 small hydropower plants have been proposed, but few have been approved. Future small hydropower plants will commit an unknown amount of Idaho's water to instream use at generating sites.

\section{MINIMUM INSTREAM FLOWS}

Idaho law provides that the IWRB may hold a water right for minimum instream flows for recreation, preservation of fish habitat, and other beneficial uses. Instream flows held as water rights by IWRB are subordinate to senior rights; however, they are constraints on future upstream uses.

As of 1980, 10 IWRB minimum streamflow applications for rivers and springs on the plain were approved or under consideration. These applications accounted for a total of $441 \mathrm{ft}^{3} / \mathrm{s}$ in six springs and four rivers. Two minimum streamflows in the Snake River have been established by the legislature: $3,300 \mathrm{ft}^{3} / \mathrm{s}$ at the gaging station near Murphy and $4,750 \mathrm{ft}^{3} / \mathrm{s}$ at the gaging station near Weiser.

\section{EVAPOTRANSPIRATION FROM WATER BODIES AND UNDEVELOPED LANDS}

About 6.4 million acres of the Snake River Plain are undeveloped land or water bodies; more than 5.2 million acres are rangeland dominated by native shrubs and grasses. Barren areas that are mostly lava flows with little or no soil cover account for about 1.0 million acres. The remainder is forests, wetlands, and water. Evapotranspiration from these areas accounts for about 48 percent of total consumptive water use on the plain and thus is an important part of the total water budget.

Evaporation on the plain, estimated from standard Class-A land pans, ranges from 40 to $55 \mathrm{in} . / \mathrm{yr}, 80$ percent of which occurs from May through October. Evaporation from open water is generally about 70 percent of land-pan evaporation. Nace and others (1957, p. 41) estimated 33 in./yr evaporation from Lake Lowell on the western plain. In a study of the 17 Western States, Meyers (1962, p. 93) estimated 34 in. average annual evaporation from open-water bodies in the Snake River basin. Measurements of pan evaporation in and near Mud Lake indicated annual evaporation rates of 37-38 in. (Stearns and others, 1939, p. 92). 

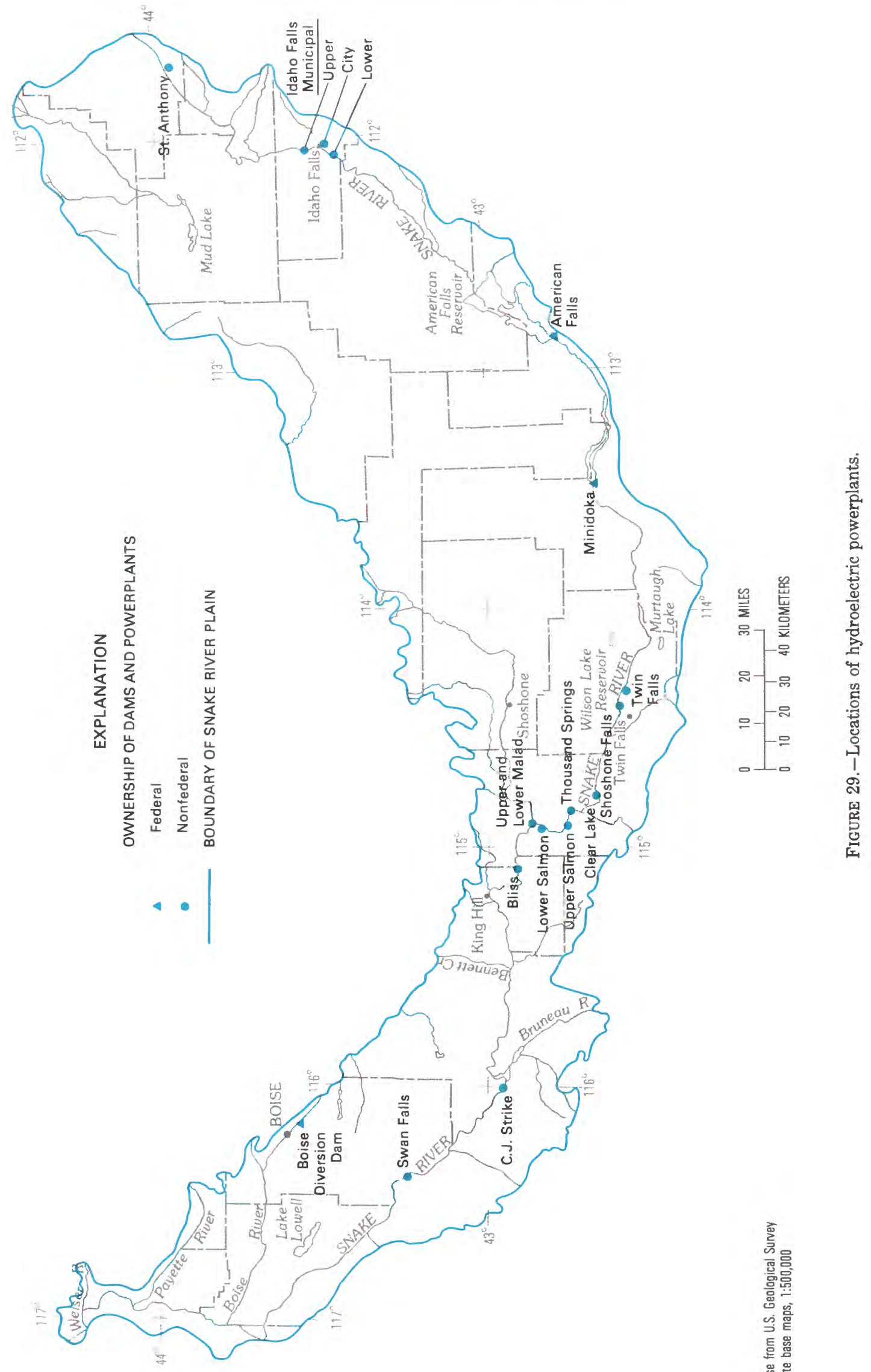
TABLE 14.-Water use for hydropower generation, 1980

\begin{tabular}{|c|c|c|c|}
\hline County & $\begin{array}{l}\text { Hydropower } \\
\text { facility }\end{array}$ & $\begin{array}{l}\text { Power } \\
\text { generated } \\
\text { (thousands } \\
\text { of kilowatt- } \\
\text { hours) }\end{array}$ & $\begin{array}{l}\text { Water used } \\
\text { (thousands of } \\
\text { acre-feet) }\end{array}$ \\
\hline \multirow[t]{2}{*}{ Ada.......... } & $\begin{array}{l}\text { Boise Diversion Dam } \\
\text { Swan Falls }\end{array}$ & $\begin{array}{r}6,880 \\
86,182 \\
\end{array}$ & $\begin{array}{r}739 \\
5,108 \\
\end{array}$ \\
\hline & & 93,062 & $\underline{5,847}$ \\
\hline \multirow[t]{2}{*}{ Bonneville... } & $\begin{array}{l}\text { Idaho Falls City Plant }{ }^{1} \\
\text { Idaho Falls Lower Plant } \\
\text { Idaho Falls Upper Plant }\end{array}$ & $\begin{array}{l}47,012 \\
60,049 \\
54,462 \\
\end{array}$ & $\begin{array}{l}2,460 \\
3,292 \\
2,986 \\
\end{array}$ \\
\hline & & 161,523 & 8,738 \\
\hline Elmore...... & C.J. Strike & $\underline{501,702}$ & 6,452 \\
\hline Fremont...... & St. Anthony & 2,522 & 247 \\
\hline \multirow[t]{2}{*}{ Gooding..... } & $\begin{array}{l}\text { Bliss } \\
\text { Clear Lake } \\
\text { Lower Malad } \\
\text { Upper Malad } \\
\text { Lower Salmon } \\
\text { Thousand Springs }\end{array}$ & $\begin{array}{r}410,565 \\
18,142 \\
120,930 \\
65,768 \\
282,923 \\
62,226 \\
\end{array}$ & $\begin{array}{r}7,247 \\
314 \\
863 \\
594 \\
5,164 \\
414 \\
\end{array}$ \\
\hline & & 960,554 & 14,596 \\
\hline Jerome...... & Shoshone Falls & 95,172 & 538 \\
\hline Minidoka.... & Minidoka & $\underline{82,964}$ & $\underline{2,159}$ \\
\hline Power....... & American Falls & 379,382 & 5,455 \\
\hline \multirow[t]{2}{*}{ Twin Falls... } & $\begin{array}{l}\text { Twin Falls } \\
\text { Upper Salmon }\end{array}$ & $\begin{array}{r}64,966 \\
280,475 \\
\end{array}$ & $\begin{array}{r}504 \\
7,169 \\
\end{array}$ \\
\hline & & 345,441 & $\underline{7,673}$ \\
\hline Total.... & $\ldots \ldots \ldots \ldots \ldots \ldots \ldots \ldots \ldots \ldots \ldots$ & $2,622,322$ & 51,705 \\
\hline
\end{tabular}

${ }^{1}$ plants were under construction in 1980 and operated only part of the year. Data are for 1982-83.

On the basis of an average open-water evaporation rate of $36 \mathrm{in} . / \mathrm{yr}$ from an estimated 107,000 acres of water, about 320,000 acre-ft is evaporated annually from water bodies on the Snake River Plain. Actual evaporation probably exceeds this estimate because the area covered by water, which was determined from digital Landsat data, probably was underestimated. Landsat sensors distinguish reflectance spectra with a spatial resolution of about 1 acre; reflectance data from smaller areas, including canals and streams, are averaged with surrounding information and are thus indistinguishable. Of the many streams and 2,700 mi of canals and laterals conveying water from the Snake River (U.S. Soil Conservation Service, 1977, p. 7), few are large enough to be distinguished by Landsat sensors.

Evaporation rates from barren areas on the plain are largely unknown. Owing to the hot, dry climate, poten- tial evaporation exceeds precipitation by a factor of 2 or more, so the upper limit of actual evaporation is annual precipitation. However, only part of precipitation is evaporated. Most barren areas on the plain are highly permeable lava flows. Compared to the rest of the plain, it is likely that some of the precipitation infiltrates to aquifers. S.P. Garabedian (U.S. Geological Survey, written commun., 1983) estimated recharge rates of 2-3 in./yr on barren areas compared with $0.5-1 \mathrm{in} . / \mathrm{yr}$ on rangelands.

Previous estimates of the amounts of precipitation that infiltrate and evaporate were based on few actual data. Measurement of evaporation was beyond the scope of this study. Most barren lands receive less than 12 in./yr of precipitation. Assuming an average of $10 \mathrm{in}$. of precipitation, 70 percent of which evaporates annually, 600,000 acre-ft/yr of water is evaporated from more than 1.0 million acres of barren area. 
More than 50 percent of the Snake River Plain is rangeland. Estimated evapotranspiration from rangeland equals about 75 percent of evapotranspiration by crops and thus is a major consumptive use of water on the plain. Evapotranspiration rates on rangelands depend on the predominant vegetation.

Range plants can be divided into two classes, depending on their relation to the water table and consequent evapotranspiration rates. Xerophytes grow above the water table and are capable of surviving on small, irregular amounts of water supplied by precipitation. Sagebrush (Artemisia tridentata) and native grasses are the most common xerophytes on the plain. Phreatophytes have roots deep enough to obtain water largely from capillary zones above the saturated zone. Having a continuous supply of water, they transpire significantly more water than xerophytes. Phreatophytes common along water courses include willow (Salix) and cottonwood (Populus). Greasewood (Sarcobatus vermiculatus) and saltgrass (Distichlis stricta) are common on alkali sites. Rabbitbrush (Chrysothamnus nauseosus), squirreltail (Hordeum), and wild rye (Elymus) grow in sandy soils where the water table is shallow.

Evapotranspiration by xerophytes may be one of the largest, but least studied, consumptive uses of water on the Snake River Plain. Potential evapotranspiration on the plain ranges from 20 to $30 \mathrm{in}$./yr (PNRBC, 1970, p. 351,421$)$. Actual evapotranspiration is limited by scant precipitation to about 6-12 in./yr. Assuming average evapotranspiration by xerophytes is $8 \mathrm{in} . / \mathrm{yr}$, then the evapotranspiration of xerophytes is probably about 3.3 million acre-ft/yr.

Although phreatophyte acreage on the Snake River Plain is small, total water use by phreatophytes is disproportionately large because of high evapotranspiration rates. Nace and others $(1957$, p. 48) used an estimated 48 in./yr to calculate phreatophyte evapotranspiration in the Boise River valley. Mower and Nace (1957, p. 21) estimated phreatophyte evapotranspiration rates in southern Idaho to be from 24 to 52 in./yr, depending on plant species. Cottonwoods and willows evapotranspire 36 to $52 \mathrm{in./yr}$, whereas greasewood, rabbitbrush, and saltgrass evapotranspire 24 to 26 in./yr. Other investigators estimated greasewood and saltgrass evapotranspiration in the Western States to be from 17 to $28 \mathrm{in} . / \mathrm{yr}$ (Meinzer, 1927, p. 20; White, 1932, p. 99-100; Robinson, 1958 , p. 58, 69).

Area covered by phreatophytic vegetation was estimated from county vegetation maps prepared by the Idaho Department of Fish and Game (1983). An estimated 200,000 acres of phreatophytes include 36,000 acres identified from Landsat data as wetlands. If phreatophytes on the Snake River Plain evapotranspire 24 in./yr, they consume about 400,000 acre-ft of water annually.

\section{TOTAL WATER WITHDRAWN AND CONSUMPTIVE WATER USE IN 1980}

Table 15 summarizes 1980 estimated withdrawals and consumptive use for offstream uses and for evaporation and transpiration from undeveloped lands and water for the Snake River Plain. Irrigation accounts for 88 percent of withdrawals and 99 percent of offstream consumptive use. Aquaculture accounts for 11 percent of withdrawals. Evaporation from open water and bare ground, and evapotranspiration by native vegetation equals about 90 percent of the consumptive use by irrigated crops.

\section{WATER-USE TRENDS, 1945 TO 1980}

Since 1945, the U.S. Geological Survey has estimated water use in each State every five years and published these estimates in a series of Circulars. The first report estimated ground-water withdrawals, and subsequent reports estimated both surface- and ground-water withdrawals. Statewide water-use trends since 1945 can be inferred from these published estimates. Withdrawals on the Snake River Plain probably followed the same trends. Withdrawals for offstream uses are shown in figure 30 , and estimated withdrawals and consumptive use for offstream and instream uses are summarized in table 16. These data should be used only to infer long-term trends because estimation methods and accuracy of data changed over the years. For example, many more municipal water-supply systems were metered in 1980 than in 1950. Also, in some years, springs were classified as surface water and, in other years, as ground water. However, even with these differences, long-term trends can be discerned.

Generally, long-term increases are evident in both instream and offstream uses. Irrigation has been by far the largest offstream use statewide; withdrawals for irrigation are 10 times greater than combined withdrawals for public and rural supplies and self-supplied industries. Surface-water withdrawals for irrigation have composed a declining but large part of total withdrawals. Since 1950, ground-water withdrawals for irrigation increased tenfold, whereas surface-water withdrawals declined slightly. In 1980, surface water withdrawn for irrigation accounted for 64 percent of total withdrawals, compared with more than 95 percent in 1950 . The decline of surface-water withdrawals probably is due to several dry years from 1977 to 1981 when streamflows were reduced and to declining water application rates as irrigators converted from gravity distribution systems to sprinklers.

Since 1950, rural- and public-supply withdrawals increased steadily as population increased. Estimated surface-water withdrawals for public supplies increased 
TABLE 15.-Summary of offstream water withdrawals and consumptive use, 1980

\begin{tabular}{|c|c|c|}
\hline Offstream use & $\begin{array}{l}\text { Withdrawal } \\
\text { (acre-feet) }\end{array}$ & $\begin{array}{l}\text { sumptive use } \\
\text { acre-feet) }\end{array}$ \\
\hline \multicolumn{3}{|l|}{ Irrigation } \\
\hline surface water............ & $12,700,000$ & $3,500,000$ \\
\hline Ground water............ & $2,300,000$ & $1,600,000$ \\
\hline Industrial. $\ldots \ldots \ldots \ldots \ldots \ldots$ & 71,300 & 5,700 \\
\hline Aquaculture............. & $1,906,000$ & 1,000 \\
\hline Nonindustrial public supply... & 102,400 & 22,000 \\
\hline 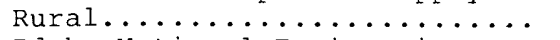 & 23,000 & 11,800 \\
\hline \multicolumn{3}{|l|}{ Idaho National Engineering } \\
\hline 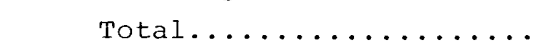 & $17,110,100$ & $5,144,400$ \\
\hline \multicolumn{3}{|l|}{ Other consumptive uses: } \\
\hline \multicolumn{2}{|c|}{$\begin{array}{l}\text { Evaporation from open water } \ldots \ldots \ldots \ldots \ldots \ldots \ldots \\
\text { Evaporation from bare ground. } \ldots \ldots \ldots \ldots \\
\text { Evapotranspiration by native vegetation. } \ldots \ldots \ldots\end{array}$} & $\begin{array}{r}320,000 \\
600,000 \\
3,700,000 \\
\end{array}$ \\
\hline \multicolumn{2}{|c|}{ 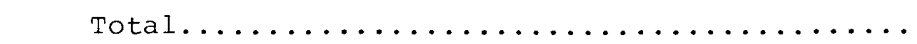 } & $4,620,000$ \\
\hline
\end{tabular}

until 1955 and then began to decline. The decline can be explained in part by two factors: (1) A few cities changed their source of public supply from surface water to ground water, and (2) data improved as meters were installed on public water-supply systems. Twin Falls is an example of a change in water source. In 1955, the city of Twin Falls obtained its public water supply from Low Line Canal, which conveys water from the Snake River at Milner Dam. Wells were added to the public water-supply system in 1957 and 1962, and in 1969, spring water completely replaced the water formerly withdrawn from Low Line Canal (Newton Everett, City of Twin Falls, oral commun., 1984).

The large increase in ground-water withdrawals for selfsupplied industries between 1965 and 1980 has two causes. (1) Beginning in 1970, aquaculture was included in the self-supplied industries category; prior to 1970 , aquaculture was excluded from water-use estimates. (2) Between 1970 and 1972, the aquaculture industry in Idaho increased about fourfold (Klontz and King, 1975, p. 56).

Instream use of water for hydropower generation has increased along with offstream uses. The large volume of water used in 1975 and the apparently small volume used in 1980 probably are due to climatic fluctuations and, thus, to the quantity of streamflows available. In 1974 and 1975, Idaho received above-normal precipitation and streamflows increased. Conversely, precipitation was below normal between 1977 and 1981. The high wateruse estimate for power generation in 1960 cannot readily be explained by climatic conditions and may be in error.

\section{SUMMARY}

Irrigation has long been the largest consumptive use of water on the Snake River Plain. Surface-water diversions for irrigation on the plain began in the 1840's in the Boise River valley. With the stimulus of Federal aid authorized by the Desert Land Act, Carey Act, and Reclamation Act, irrigated area increased rapidly in the early 1900's. By 1929, 2.2 million acres were irrigated. Ground water became an important source of irrigation water after World War II.

In 1980, about 3.1 million acres on the Snake River Plain were irrigated. An estimated 2.3 million acre-ft of ground water was withdrawn from about 5,300 wells to irrigate 1.0 million acres. Another 12.7 million acre-ft of water was pumped or gravity diverted from the Snake River and its major tributaries to irrigate 2.0 million acres. Gravity diversions accounted for 11.8 million acre-ft and 940,000 acre-ft was withdrawn by river pumps. Combined surface and ground water irrigated 0.1 million acres.

Historical changes in aquifer storage and ground-water discharge are closely related to changes in irrigationwater use. From the late 1800's to about 1950, most crops were irrigated with surface water. Surface-water irrigation diversions typically have exceeded crop-irrigation requirements by a factor of 2 or more, and much of the excess water has become ground-water recharge. From 1890 to 1952 , additional recharge caused an average water-level rise of $50 \mathrm{ft}$ in wells on the eastern plain and a corresponding 24 million acre-ft increase in aquifer storage. During the same period, ground-water discharge 
from the eastern plain to the Snake River between Milner and King Hill increased from 4,200 to $6,800 \mathrm{ft}^{3} / \mathrm{s}$. Waterlevel rises also were reported on the western plain between 1912 and the mid-1930's.

Since the early 1950's, net ground-water recharge from irrigation declined as a result of increased ground-water pumpage and more efficient use of water. In the 1960's and 1970's, many farms converted from gravity to sprinkler distribution systems. During the same period, water levels declined a few to tens of feet across the plain

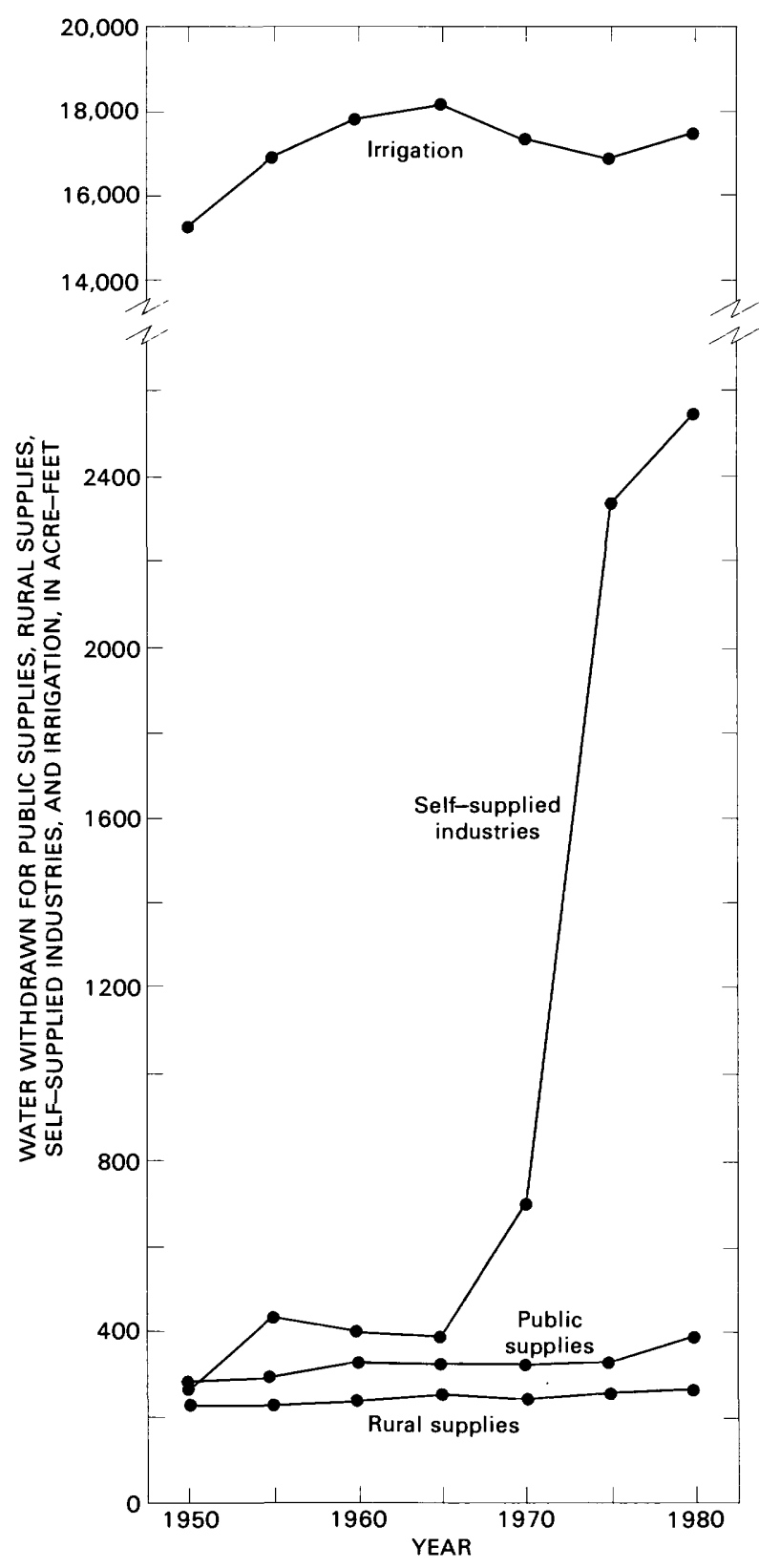

FIGURE 30.-Trends in withdrawals for offstream uses, 19501980. and more than 100 feet in local areas. Ground-water discharge between Milner and King Hill declined $600 \mathrm{ft}^{3} / \mathrm{s}$ from 1951 to 1980.

The aquaculture industry uses large amounts of spring water, very little of which is consumptively used. In 1980, an estimated 1.9 million acre-ft, mostly ground water, was withdrawn for commercial and public fish farms. Excluding aquaculture, industries on the Snake River Plain withdrew about 70,000 acre-ft, 90 percent from ground water and 10 percent from surface water.

Other withdrawals for offstream uses totaled about 132,000 acre-ft; 102,000 for nonindustrial public supplies, 23,000 for rural supplies, and 7,000 for use at Idaho National Engineering Laboratory of the U.S. Department of Energy. An estimated 38,000 acre-ft of these withdrawals was consumptively used.

By far the largest instream use of water in the Snake River Plain is for hydroelectric power generation. In 1980, an estimated 52 million acre-ft of surface water passed through hydropower facilities on the plain, generating 2.6 million MWh of electricity. Although none of the water is consumptively used, water rights for hydropower generation and other instream uses partially control availability of water for other uses.

An estimated 48 percent of consumptive water use on the plain is evapotranspiration from rangelands and wetlands and evaporation from open water and bare ground. More than half of the Snake River Plain is undeveloped rangeland; xerophytic and phreatophytic vegetation evapotranspires an estimated 3.7 million acre$\mathrm{ft} / \mathrm{yr}$. Another 900,000 acre-ft/yr evaporates from bare ground and open water.

\section{REFERENCES CITED}

Association of Idaho Cities, 1980, Municipal water use survey: Unpublished data on file in Boise, Idaho, office of U.S. Geological Survey.

Bigelow, B.B., Goodell, S.A., and Newton, G.D., 1984, Water withdrawn for irrigation in 1980 on the Snake River Plain, Idaho and eastern Oregon: U.S. Geological Survey Open-File Report 84-434, scale $1: 1,000,000,2$ sheets.

Burnham, W.L., Crosthwaite, E.G., Norvitch, R.F., Waite, H.A., and Walker, E.H., 1966, Summary of ground-water conditions in Idaho, 1966: Idaho Department of Reclamation, Water Information Bulletin no. $1,60 \mathrm{p}$.

Caldwell, H.H., and Wells, Merle, 1974, Boise post-audit study, economic and ecological history support study: Moscow, Idaho Water Resources Research Institute, $180 \mathrm{p}$.

Center for Business Development and Research, 1982, Manufacturing directory of Idaho: Moscow, University of Idaho, $167 \mathrm{p}$.

Guyton, W.F., 1950, Estimated use of ground water in the United States, 1945: U.S. Geological Survey Open-File Report, 5 p.

Hoyt, W.G., 1935, Water utilization in the Snake River basin: U.S. Geological Survey Water-Supply Paper 657, 379 p.

Idaho Crop and Livestock Reporting Service, 1982, Idaho agricultural statistics: Boise, $72 \mathrm{p}$. 
TABLE 16.-Estimated water

$[--$, data not available; values in

\begin{tabular}{|c|c|c|c|c|c|c|c|c|c|c|}
\hline \multirow[b]{2}{*}{ Year } & \multicolumn{4}{|c|}{ Irrigation } & \multicolumn{3}{|c|}{ Pub1 ic supply } & \multicolumn{3}{|c|}{ Rura1 supply } \\
\hline & $\begin{array}{l}\text { Ground } \\
\text { water } \\
\text { with- } \\
\text { drawal }\end{array}$ & $\begin{array}{l}\text { Surface } \\
\text { water } \\
\text { with- } \\
\text { drawa1 }\end{array}$ & $\begin{array}{c}\text { National } \\
\text { rank } \\
\text { with- } \\
\text { drawal }\end{array}$ & $\begin{array}{l}\text { Consump- } \\
\text { tive use }\end{array}$ & $\begin{array}{l}\text { Ground } \\
\text { water } \\
\text { with- } \\
\text { drawa1 }\end{array}$ & $\begin{array}{l}\text { Surface } \\
\text { water } \\
\text { with- } \\
\text { drawal }\end{array}$ & $\begin{array}{l}\text { Consump- } \\
\text { tive use }\end{array}$ & $\begin{array}{l}\text { Ground } \\
\text { water } \\
\text { with- } \\
\text { drawal }\end{array}$ & $\begin{array}{l}\text { Surface } \\
\text { water } \\
\text { with- } \\
\text { drawal }\end{array}$ & $\begin{array}{l}\text { Consump- } \\
\text { tive use }\end{array}$ \\
\hline 1945 & 140 & - & 2 & - & 28 & - & - & 22 & - & - \\
\hline 1950 & 350 & 15,000 & 2 & - & 56 & 28 & - & 22 & 11 & - \\
\hline 1955 & 1,200 & 15,700 & 2 & - & 63 & 34 & - & 17 & 11 & - \\
\hline 1960 & 2,800 & 15,000 & 2 & 5,000 & 100 & 31 & 21 & 32 & 13 & 27 \\
\hline 1965 & 3,100 & 15,000 & 2 & 5,100 & 100 & 26 & 8 & 32 & 13 & 26 \\
\hline 1970 & 2,300 & 15,000 & 2 & 5,200 & 110 & 17 & 32 & 36 & 16 & 28 \\
\hline 1975 & 3,900 & 13,000 & 2 & 5,300 & 120 & 11 & 38 & 52 & 7 & 29 \\
\hline 1980 & 4,500 & 13,000 & 2 & 6,300 & 170 & 18 & 57 & 59 & 17 & 33 \\
\hline
\end{tabular}

${ }^{1}$ Guyton (1950)

2 MacKichan (1951)

${ }^{3}$ MacKichan (1957)

${ }^{4}$ Mackichan and Kammerer (1961)

"Murray (1968)

Murray (1972)

${ }^{7}$ Murray and Reeves (1977)

${ }^{8}$ Solley and others (1983)

Idaho Department of Fish and Game, 1980, Annual hatchery reports, Volume 1: Boise, Fisheries Division Publications.

1983, County vegetation maps: Unpublished data on file in Boise, Idaho, office.

Idaho Department of Water Resources, 1978, Water-related land use1975: Idaho Department of Water Resources, scale 1:126,720, 16 county map sheets.

1980a, Report on canal deliveries from Boise River and different features affecting these deliveries for the irrigation season of 1980: Boise, Annual Report, 13 p.

1980b, Snake River and tributaries above Milner, Idaho: Idaho Falls, Idaho, Annual Report, Water District 1, 72 p.

$1980 \mathrm{c}$, Water distribution and hydrometric work in Water District \#37, Big Wood River and Water District \#37-M, Silver Creek and Little Wood River: Shoshone, Idaho, Annual Report, 149 p.

1983 , Industrial water use: Unpublished data on file in Boise, Idaho, office.

Idaho Division of Economic and Community Affairs, 1983, Idaho facts: Boise, pamphlet.

Idaho Water Resource Board, 1970, Irrigated and potentially irrigable lands in Idaho: U.S. Geological Survey, scale 1:650,000. 1972 , Interim State water plan: Boise, $265 \mathrm{p}$.

Johnson, G.S., Brockway, C.E., and Luttrell, S.P., 1982, Application of a numerical ground-water flow model to the Mud Lake area in southeastern Idaho: Moscow, University of Idaho, unpublished thesis, $58 \mathrm{p}$.

Kjelstrom, L.C., 1984, Flow characteristics of the Snake River and water budget for the Snake River Plain, Idaho and eastern Oregon: U.S. Geological Survey Open-File Report 84-052, scale 1:1,000,000, 2 sheets.

Klontz, G.W., and King, J.G., 1975, Aquaculture in Idaho and nationwide: Boise, Idaho Department of Water Resources, $174 \mathrm{p}$.

Lewis, B.D., and Jensen, R.G., 1985, Hydrologic conditions at the Idaho
National Engineering Laboratory, Idaho, 1979-1981 update: U.S. Geological Survey Hydrologic Investigations Atlas HA-674, 2 sheets. Lindholm, G.F., 1981, Plan of study for the regional aquifer-system analysis of the Snake River Plain, Idaho and eastern Oregon: U.S. Geological Survey Open-File Report 81-689, 21 p.

Lindholm, G.F., Garabedian, S.P., Newton, G.D., and Whitehead, R.L., 1983, Configuration of the water table, March 1980, in the Snake River Plain regional aquifer system, Idaho and eastern Oregon: U.S. Geological Survey Open-File Report 82-1022, scale 1:500,000.

Lindholm, G.F., and Goodell, S.A., 1984, Irrigated acreage and other land uses on the Snake River Plain, Idaho and eastern Oregon: U.S. Geological Survey Open-File Report 84-452, scale 1:500,000.

MacKichan, K.A., 1951, Estimated use of water in the United States, 1950: U.S. Geological Survey Circular 115, 13 p.

1957, Estimated use of water in the United States, 1955: U.S. Geological Survey Circular 398, $18 \mathrm{p}$.

MacKichan, K.A., and Kammerer, J.C., 1961, Estimated use of water in the United States, 1960: U.S. Geological Survey Circular 456, $26 \mathrm{p}$.

Meinzer, O.E., 1927, Plants as indicators of ground water: U.S. Geological Survey Water-Supply Paper 577, 95 p.

Meyers, J.S., 1962, Evaporation from the 17 Western States: U.S. Geological Survey Professional Paper 272-D, 100 p.

Mower, R.W., and Nace, R.L., 1957, Water consumption by water-loving plants in the Malad Valley, Oneida County, Idaho: U.S. Geological Survey Water-Supply Paper 1412, 33 p.

Mundorff, M.J., Crosthwaite, E.G., and Kilburn, Chabot, 1964, Ground water for irrigation in the Snake River basin in Idaho: U.S. Geological Survey Water-Supply Paper 1654, 224 p.

Murray, C.K., 1968, Estimated use of water in the United States, 1965: U.S. Geological Survey Circular 556, 53 p.

1972, Estimated use of water in the United States in 1970: U.S. Geological Survey Circular 676, 37 p. 
use in Idaho, $1945-1980$

thousands of acre-feet per year]

\begin{tabular}{|c|c|c|c|c|c|c|c|c|}
\hline \multicolumn{3}{|c|}{ Self-supplied industry } & \multicolumn{4}{|c|}{ Total offstream use } & \multicolumn{2}{|c|}{ Hydropower generation } \\
\hline $\begin{array}{l}\text { Ground } \\
\text { water } \\
\text { with- } \\
\text { drawal }\end{array}$ & $\begin{array}{l}\text { Surface } \\
\text { water } \\
\text { with- } \\
\text { drawal }\end{array}$ & $\begin{array}{l}\text { Consump- } \\
\text { tive use }\end{array}$ & $\begin{array}{l}\text { Ground } \\
\text { water } \\
\text { with- } \\
\text { drawal }\end{array}$ & $\begin{array}{l}\text { Surface } \\
\text { water } \\
\text { with- } \\
\text { drawal }\end{array}$ & $\begin{array}{l}\text { Total } \\
\text { with- } \\
\text { drawal }\end{array}$ & $\begin{array}{c}\text { National } \\
\text { rank } \\
\text { with- } \\
\text { drawal }\end{array}$ & $\begin{array}{l}\text { Instream } \\
\text { use }\end{array}$ & $\begin{array}{c}\text { National } \\
\text { rank }\end{array}$ \\
\hline 11 & - & - & 200 & - & - & - & - & - \\
\hline 56 & 17 & - & 480 & 15,200 & 15,700 & 3 & 34,000 & 15 \\
\hline 130 & 100 & - & 1,400 & 15,800 & 17,200 & 3 & 68,300 & 8 \\
\hline 100 & 100 & 40 & 3,000 & 15,100 & 18,100 & 3 & 134,400 & 6 \\
\hline 100 & 87 & 13 & 3,300 & 15,100 & 18,400 & 5 & 97,000 & 9 \\
\hline 380 & 120 & 18 & 2,800 & 15,100 & 17,900 & 7 & 94,000 & 8 \\
\hline 2,100 & 130 & 170 & 6,200 & 13,100 & 19,300 & 6 & 100,000 & 7 \\
\hline 2,400 & 130 & 200 & 7,100 & 13,200 & 20,300 & 5 & 85,000 & 10 \\
\hline
\end{tabular}

Murray, C.K., and Reeves, E.B., 1977, Estimated use of water in the United States in 1975: U.S. Geological Survey Circular 765, 39 p.

Nace, R.L., West, S.W., and Mower, R.W., 1957, Feasibility of groundwater features of the alternate plan for the Mountain Home Project, Idaho: U.S. Geological Survey Water-Supply Paper 1376, 121 p.

Newell, F.H., 1903, First annual report of the Reclamation Service: Washington, U.S. Geological Survey, 317 p.

Norvitch, R.F., Thomas, C.A., and Madison, R.J., 1969, Artificial recharge to the Snake Plain aquifer; an evaluation of potential and effect: Idaho Department of Reclamation, Water Information Bulletin no. 12, $59 \mathrm{p}$.

Oregon Crop and Livestock Reporting Service, 1982, Oregon agricultural statistics: Portland, Oreg., 60 p.

Oregon Economic Development Department, 1983, Directory of Oregon manufacturers, 1982-1983: Salem, Oreg., p. 73.

Pacific Northwest River Basins Commission, 1970, Columbia-North Pacific region comprehensive framework study of water and related lands, Appendix V, v. 1 and 2, Water resources: Vancouver, Wash., $2033 \mathrm{p}$.

1971a, Columbia-North Pacific region comprehensive framework study of water and related lands, Appendix IX, Irrigation: Vancouver, Wash., $343 \mathrm{p}$.

1971b, Columbia-North Pacific region comprehensive framework study of water and related lands, Appendix XI, Municipal and industrial water supply: Vancouver, Wash., $257 \mathrm{p}$.

1981, Irrigated lands in the Pacific Northwest, 1980: Vancouver, Wash., $33 \mathrm{p}$

Rich, L.R., 1952, Forest and range vegetation: Transactions of the American Society of Civil Engineers, v. 117, p. 974-987.

Robinson, T.W., 1958, Phreatophytes: U.S. Geological Survey WaterSupply Paper 1423, 84 p.

Seitz, H.R., LaSala, A.M., and Moreland, J.A., 1977, Effects of drain wells on the ground-water quality of the western Snake Plain aquifer, Idaho: U.S. Geological Survey Open-File Report 76-673, 34 p.

Simons, W.D., 1953, Irrigation and streamflow depletion in Columbia River Basin above The Dalles, Oregon: U.S. Geological Survey Water-Supply Paper 1220, 126 p.

Solley, W.B., Chase, E.B., and Mann, W.B. IV, 1983, Estimated use of water in the United States in 1980: U.S. Geological Survey Circular $1001,56 \mathrm{p}$.

Stearns, H.T., Bryan, L.L., and Crandall, Lynn, 1939, Geology and water resources of the Mud Lake region, Idaho: U.S. Geological Survey
Water-Supply Paper 818, 125 p.

Stearns, H.T., Crandall, Lynn, and Steward, W.G., 1938, Geology and ground-water resources of the Snake River Plain in southeastern Idaho: U.S. Geological Survey Water-Supply Paper 774, 268 p.

Sutter, R.J., and Corey, G.L., 1970, Consumptive irrigation requirements for crops in Idaho: Moscow, University of Idaho Bulletin 516, $97 \mathrm{p}$.

U.S. Bureau of the Census, 1981, 1978 census of agriculture-Idaho: State and county data: v. 1, pt. 12, 442 p.

U.S. Bureau of Reclamation, 1946, Development of water and other resources present and potential of the Columbia River basin: Washington, $540 \mathrm{p}$.

1980, Irrigatied acreage in Idaho in 1979: Unpublished maps compiled for the Pacific Northwest River Basins Commission, on file in Boise, Idaho, office.

U.S. Department of Commerce, 1980, Climatological data, Idaho: National Oceanic and Atmospheric Administration, Annual summary, v. 83 , no. 13,13 p.

U.S. Soil Conservation Service, 1976, Snake River basin, Idaho and Wyoming cooperative study-land resource data: Boise, $77 \mathrm{p}$

1977, Snake River basin, Idaho and Wyoming cooperative study-Irrigation water distribution and use: Boise, $69 \mathrm{p}$.

Walker, E.H., Dutcher, L.C., Decker, S.O., and Dyer, K.L., 1970, The Raft River basin, Idaho-Utah, as of 1966-A reappraisal of the water resources and effects of ground-water development: U.S. Geological Survey Open-File Report, $116 \mathrm{p}$.

White, W.N., 1932, A method of estimating ground-water supplies based on discharge by plants and evaporation from soils: U.S. Geological Survey Water-Supply Paper 659-A, p. 1-106.

Whitehead, R.L., 1984, Geohydrologic framework of the Snake River Plain, Idaho and eastern Oregon: U.S. Geological Survey Open-File Report 84-051, scale 1:1,000,000, 3 sheets.

Young, H.W., 1977, Reconnaissance of ground-water resources in the Mountain Home plateau area, southwest Idaho: U.S. Geological Survey Water-Resources Investigations 77-108, $40 \mathrm{p}$.

Young, H.W., and Harenberg, W.A., 1971, Ground-water pumpage from the Snake Plain aquifer, southeastern Idaho: Idaho Department of Water Administration, Water Information Bulletin no. 23, $28 \mathrm{p}$.

Young, H.W., and Whitehead, R.L., 1975, Geothermal investigations in Idaho, an evaluation of thermal water in the Bruneau-Grand View area, southwest Idaho: Idaho Department of Water Resources, Water Information Bulletin no. 30, pt. 2, 50 p. 


. 


\section{SELECTED SERIES OF U.S. GEOLOGICAL SURVEY PUBLICATIONS}

\section{Periodicals}

Earthquakes \& Volcanoes (issued bimonthly).

Preliminary Determination of Epicenters (issued monthly).

\section{Technical Books and Reports}

Professional Papers are mainly comprehensive scientific reports of wide and lasting interest and importance to professional scientists and engineers. Included are reports on the results of resource studies and of topographic, hydrologic, and geologic investigations. They also include collections of related papers addressing different aspects of a single scientific topic.

Bulletins contain significant data and interpretations that are of lasting scientific interest but are generally more limited in scope or geographic coverage than Professional Papers. They include the results of resource studies and of geologic and topographic investigations; as well as collections of short papers related to a specific topic.

Water-Supply Papers are comprehensive reports that present significant interpretive results of hydrologic investigations of wide interest to professional geologists, hydrologists, and engineers. The series covers investigations in all phases of hydrology, including hydrogeology, availability of water, quality of water, and use of water.

Circulars present administrative information or important scientific information of wide popular interest in a format designed for distribution at no cost to the public. Information is usually of short-term interest.

Water-Resources Investigations Reports are papers of an interpretive nature made available to the public outside the formal USGS publications series. Copies are reproduced on request unlike formal USGS publications, and they are also available for public inspection at depositories indicated in USGS catalogs.

Open-File Reports include unpublished manuscript reports, maps, and other material that are made available for public consultation at depositories. They are a nonpermanent form of publication that may be cited in other publications as sources of information.

\section{Maps}

Geologic Quadrangle Maps are multicolor geologic maps on topographic bases in $71 / 2$ - or 15 -minute quadrangle formats (scales mainly $1: 24,000$ or $1: 62,500$ ) showing bedrock, surficial, or engineering geology. Maps generally include brief texts; some maps include structure and columnar sections only.

Geophysical Investigations Maps are on topographic or planimetric bases at various scales; they show results of surveys using geophysical techniques, such as gravity, magnetic, seismic, or radioactivity, which reflect subsurface structures that are of economic or geologic significance. Many maps include correlations with the geology.

Miscellaneous Investigations Series Maps are on planimetric or topographic bases of regular and irregular areas at various scales; they present a wide variety of format and subject matter. The series also includes 7 1/2-minute quadrangle photogeologic maps on planimetric bases which show geology as interpreted from aerial photographs. Series also includes maps of Mars and the Moon.
Coal Investigations Maps are geologic maps on topographic or planimetric bases at various scales showing bedrock or surficial geology, stratigraphy, and structural relations in certain coal-resource areas.

Oil and Gas Investigations Charts show stratigraphic information for certain oil and gas fields and other areas having petroleum potential.

Miscellaneous Field Studies Maps are multicolor or black-andwhite maps on topographic or planimetric bases on quadrangle or irregular areas at various scales. Pre-1971 maps show bedrock geology in relation to specific mining or mineral-deposit problems; post-1971 maps are primarily black-and-white maps on various subjects such as environmental studies or wilderness mineral investigations.

Hydrologic Investigations Atlases are multicolored or black-andwhite maps on topographic or planimetric bases presenting a wide range of geohydrologic data of both regular and irregular areas; principal scale is $1: 24,000$ and regional studies are at $1: 250,000$ scale or smaller.

\section{Catalogs}

Permanent catalogs, as well as some others, giving comprehensive listings of U.S. Geological Survey publications are available under the conditions indicated below from the U.S. Geological Survey, Books and Open-File Reports Section, Federal Center, Box 25425, Denver, CO 80225. (See latest Price and Availability List.)

"Publications of the Geological Survey, 1879-1961" may be purchased by mail and over the counter in paperback book form and as a set of microfiche.

"Publications of the Geological Survey, 1962- 1970" may be purchased by mail and over the counter in paperback book form and as a set of microfiche.

"Publications of the U.S. Geological Survey, 1971-1981" may be purchased by mail and over the counter in paperback book form (two volumes, publications listing and index) and as a set of microfiche.

Supplements for 1982, 1983, 1984, 1985, 1986, and for subsequent years since the last permanent catalog may be purchased by mail and over the counter in paperback book form.

State catalogs, "List of U.S. Geological Survey Geologic and Water-Supply Reports and Maps For (State)," may be purchased by mail and over the counter in paperback booklet form only.

"Price and Availability List of U.S. Geological Survey Publications," issued annually, is available free of charge in paperback booklet form only.

Selected coples of a monthly catalog "New Publications of the U.S. Geological Survey" available free of charge by mail or may be obtained over the counter in paperback booklet form only. Those wishing a free subscription to the monthly catalog "New Publications of the U.S. Geological Survey" should write to the U.S. Geological Survey, 582 National Center, Reston, VA 22092.

Note.--Prices of Government publications listed in older catalogs, announcements, and publications may be incorrect. Therefore, the prices charged may differ from the prices in catalogs, announcements, and publications. 